\title{
A matrilin-1 gén transzkripciós szabályozásának vizsgálata transzgenikus egerekben
}

\author{
Ph.D. értekezés
}

Nagy Andrea

Témavezetö: Dr. Kiss Ibolya

MTA Szegedi Biológiai Központ Biokémiai Intézet

\author{
Biológia Doktori Iskola \\ Szegedi Tudományegyetem \\ Természettudományi és Informatikai Kar
}

2011

Szeged 


\section{TARTALOMJEGYZÉK}

RÖVIDÍTÉSEK JEGYZÉKE 4

IRODALMI ÁTTEKINTÉS 6

1. A PORCSZÖVET FELÉPÍTÉSE, A PORCOS VÁZELEMEK KIALAKULÁSA ÉS A VÉGTAGOK MORFOGENEZISE 6

1.1. A porcszövet és makromolekulái 6

1.2. A matrilin család

1.3. A matrilin-1 9

1.4. A porcos vázelemek képződése $\quad 10$

1.5. A chondrogenezist és a csontok hosszanti növekedését szabályozó fontosabb jelátviteli utak $\quad 12$

1.6. A vázfejlődés morfogenetikus szabályozása 13

2. AZ EUKARIÓTA GÉNEK TRANSZKRIPCIÓS SZABÁLYOZÁSA 15

2.1. Az eukarióta génexpresszió szabályozásának lehetőségei 15

2.2. A transzkripciós szabályozásban résztvevő fontosabb fehérje komponensek 16

2.3. A transzkripciós szabályozásban résztvevő DNS elemek 17

2.4. A transzgenikus állatmodellek szerepe az eukarióta génreguláció $\begin{array}{ll}\text { tanulmányozásában } & 19\end{array}$

3. A PORCSPECIFIKUS GÉNEXPRESSZIÓ TRANSZKRIPCIÓS SZABÁLYOZÁSA 20

3.1. A Sox trió 20

3.2. A Sox trió által szabályozott porc mátrix fehérjéket kódoló gének 22

3.3. A matrilin-1 gén szerkezete és transzkripciós szabályozása 23

CÉLKITÜZÉSEK 25

ANYAGOK ÉS MÓDSZEREK 26

1. Plazmid konstrukciók 26

1.1. Tranziens expressziós kísérletekhez használt plazmidok készítése 26

1.2. Transzgenikus egerek előállításához használt plazmidok készítése 27

2. Transzgenikus egerek előállítása 28

3. A transzgének jelenlétének igazolása 28

3.1. PCR 28

3.2. Dot blot 29 
4. A $\beta$-galaktozidáz aktivitás detektálása egész embrión és metszeten 29

5. Alkalmazott sejtkultúrák készítése 30

6. Tranziens expresszió 31

7. Fehérje expresszió és tisztítás 31

8. Sejtmagi kivonatok készítése EMSA és pull down kísérletekhez 31

9. EMSA 32

10. Pull down 32

ELÖZETES EREDMÉNYEK 33

EREDMÉNYEK 36

1. A rövid promoter szerepe a matrilin-1 gén expressziójának szabályozásában 36

1.1. A rövid promoter aktivitása alacsony transzgenikus egerekben 36

1.2. Távoli homológ régiók növelik a rövid promoter aktivitását 38

1.3. A matrilin-1 rövid promoter felülírja az erős heterológ porcspecifikus enhancer elem hatását 41

2. A rövid promoter szabályozó elemeit érintő mutációk hatása a matrilin-1 génexpresszióra

2.1. A Pe1 elem Sox kötőhelyeinek mutációja megszünteti a hosszú promoter aktivitását porcsejtekben $\quad 45$

2.2. Az Ine elem Sox kötőhelyeinek szerepe 49

3. Távoli homológ reguláló elemek szerepe a matrilin-1 gén expressziójának szabályozásában 53

3.1. Disztális elemek hatása a rövid promoter aktivitására 53

3.2. Disztális elemek hatása heterológ promoter aktivitására 58

3.3. Homológ introni elemek hatása a rövid promoter aktivitására $\quad 60$

AZ EREDMÉNYEK ÖSSZEFOGLALÁSA 64

DISZKUSSZIÓ 66

KÖSZÖNETNYILVÁNÍTÁS

IRODALOMJEGYZÉK

A TÉZISEK ÖSSZEFOGLALÁSA 86

$\begin{array}{ll}\text { SUMMARY OF THE THESIS } & 91\end{array}$

A DOLGOZAT ALAPJÁUL SZOLGÁLÓ KÖZLEMÉNYEK 95 


\section{RÖVIDÍTÉSEK JEGYZÉKE}

AER

$\mathrm{AMH}$

AP

ATP

BMP

BRE

cAMP

CBP

CD-RAP

CEC

CEF

CMP

CREB

DMEM

Dpe1 és Dpe2

DPE

DTT

DV

ECM

EGF

EMSA

FCS

FGF

FGFR

GST

HAM (F12)

HAT

HDAC

HDM

HMG

Ihh apikális ektodermális gerinc (apical ectodermal ridge)

anti-Müllerian hormon

antero-poszterior tengely

adenozin trifoszfát

bone morphogenetic protein

TFIIB felismerő elem (TFIIB recognition element)

ciklikus adenozin monofoszfát

CREB kötő fehérje (CREB binding protein)

cartilage-derived retinoic acid-sensitive protein

csirke embrionális chondrocyta

csirke embrionális fibroblaszt

cartilage matrix protein

cyclic-AMP response element binding

Dulbecco's modified eagle's medium

disztális promoter elem 1 és 2

downstream promoter elem

ditiotreitol

dorzo-ventrális tengely

extracelluláris mátrix

epidermális növekedési faktor (epidermal growth factor)

electrophoretic mobility shift assay

fetal calf serum

fibroblaszt növekedési faktor (fibroblast growth factor)

fibroblaszt növekedési faktor receptor

glutation S-transzferáz

nutrient mixture (F-12)

hiszton acetil-transzferáz

hiszton deacetiláz

nagy sűrüségű mesenchyma (high-density mesenhyme)

high-mobility group

Indian hedgehog 


\begin{tabular}{|c|c|}
\hline IL1 & interleukin 1 \\
\hline Ine & iniciátor elem \\
\hline $\mathrm{Inr}$ & iniciáló elemek \\
\hline Matn1 & csirke matrilin-1 gén \\
\hline MMP & mátrix metalloproteináz \\
\hline NFI & nukleáris faktor-I \\
\hline NRE & negatív szabályozó elemek (negative regulatory elements) \\
\hline PD & proximo-disztális tengely \\
\hline Pe1 & promoter elem 1 \\
\hline PG & proteoglikán \\
\hline PIC & preiniciációs komplex \\
\hline PKA & cAMP-függő protein kináz A \\
\hline PMSF & fenil-metil-szulfonil-fluorid \\
\hline polII & RNS polimeráz II \\
\hline PPR & parathyroid hormone-related peptide receptor \\
\hline PTHrP & parathyroid hormone-related peptide \\
\hline RA & retinasav \\
\hline $\mathrm{SF}-1$ & steroidogenic factor-1 \\
\hline Shh & Sonic hedgehog \\
\hline SI és SII & silencer elem I és II \\
\hline Sox & sry-type HMG box protein \\
\hline Sry & sex-determining region $\mathrm{Y}$ \\
\hline TAF & TBP-aszociált faktorok \\
\hline TBP & TATA-kötő fehérje (TATA-binding protein) \\
\hline $\mathrm{TNF} \alpha$ & tumor nekrózis faktor $\alpha$ \\
\hline VEGF & vascular endothelial growth factor \\
\hline vWFA & von Willebrand faktor A \\
\hline ZPA & polarizációs zóna (zone of polarizing activity) \\
\hline ZRS & ZPA szabályozó szekvencia (ZPA regulatory sequence) \\
\hline
\end{tabular}




\section{IRODALMI ÁTTEKINTÉS}

\section{A PORCSZÖVET FELÉPÍTÉSE, A PORCOS VÁZELEMEK KIALAKULÁSA ÉS A VÉGTAGOK MORFOGENEZISE}

\subsection{A porcszövet és makromolekulái}

A porcszövet a gerinces vázfejlődésben és a vázrendszer múködésében fontos szerepet betöltő szövettípus. Sejtes komponensei a chondrocyták, melyek a porcszövetre jellemző makromolekulákat termelik. Ezek a sejten kívüli térben egy jól szervezett extracelluláris mátrixot (ECM) hoznak létre, amely meghatározza a szövet fizikai és kémiai tulajdonságait. A porcszövetre jellemző a kiterjedt extracelluláris mátrix és a viszonylag alacsony sejtszám.

A porcszövet a csontosodás folyamatában egy átmeneti struktúra. Egyedülálló szövettípus, mivel a csontfejlődés során teljes mértékben átalakul. Ezalatt a sejtek egy többlépcsős differenciálódási folyamaton mennek keresztuil. Minden lépésben az adott stádiumra jellemző markergének kifejeződése figyelhető meg. A porcszövet ezen tulajdonsága miatt rendkívül alkalmas a sejtdifferenciálódás folyamatainak és azok szabályozásának tanulmányozására.

Az extracelluláris mátrix a sejtek közötti teret kitöltő sajátos szerkezetű állomány, melynek makromolekuláit a sejtek termelik. Szerepe sokrétü, többek között biztosítja a sejtek müködéséhez szükséges teret, támaszt nyújt, elősegíti a sejtek letapadását, vagy mozgását, tápanyagokat, növekedési faktorokat, jelmolekulákat, hormonokat közvetít a sejtekhez. Szoros kölcsönhatásban áll a sejtekkel és a benne lejátszódó változások génexpressziós változásokat is előidézhetnek.

$\mathrm{Az}$ extracelluláris mátrixot három fő molekulatípus építi fel: kollagének és egyéb fibrilláris fehérjék, a hialuronsav és proteoglikánok, multiadhéziós fehérjék.

A kollagének minden szövet sejtközötti állományának fő alkotói. Olyan oldhatatlan glikoproteinek, melyekben a (Gly-X-Y)n ismétlődések jellegzetes hármas hélixet alkotnak.

A kollagéneken kívül más fibrilláris fehérjék is részt vesznek a sejtközötti állomány felépítésében. Ilyenek az elasztikus rostokat alkotó fibrillin és elasztin, melyek föleg az erek falában, tüdőben, bőrben és az ízületi szalagokban fordulnak elő [1]. 
A poliszacharidok szabadon, vagy egy core proteinhez kovalensen kötve fordulnak elő. Jellemzőjük a nagy negatív töltéssürüség, ami fokozza vízmegkötő képességüket, így aggregátumaiknak szerepük van a sejtek turgornyomásának fenntartásában.

A hialuronsav az egyetlen olyan glükózaminoglikán, ami szabad formában van. 100050000 diszacharid egységből épül fel, a hialektánokkal (versikán, aggrekán) kapcsolódva viszkózus, hidratált gélt képez.

A proteoglikánok (PG) két nagyobb csoportba sorolhatók: mátrix proteoglikánok és sejtfelszíni proteoglikánok. Ezeken belül a PG-ok további alcsoportokba sorolhatók méretük, szerkezeti felépítésük, a core protein sajátosságai és génhomológia alapján. Biológiai funkciójuk nem merül ki abban, hogy a mátrix szerkezeti elemei, szerepük van még a sejtek osztódásában, migrációban, letapadásban, differenciálódásban [2].

A multiadhéziós fehérjék nagy része glikoprotein. Szerepük az ECM-ECM és sejtECM kölcsönhatások közvetítése. Ilyen például a link protein, ami a proteoglikánokat és a hialuronsavat kapcsolja össze, illetve a laminin, ami a bazális membrán fö alkotórészeként azt a sejtekhez köti [3].

A porcszövet sejtközötti állományának alapját is egy kollagén hálózat alkotja, melynek nagy része II. típusú kollagén, illetve IX. és XI. típusú kollagén [4]. A kollagének fibrillumai hálózatokat képeznek, melyek a nyíróerökkel szemben nagy ellenállást biztosítanak. A kollagén hálózatokhoz szorosan kapcsolódnak a proteoglikánok, melyek negatív töltésük révén vízmolekulákat kötnek meg. A proteoglikánok legnagyobb része aggrekán, melynek core proteinjéhez kapcsolódnak a kondroitin-szulfát és keratán-szulfát oldalláncok. A szintén nagy vízmegkötőképességű glükózaminoglikánok közül a porcszövetben föként a hialuronsav fordul elö, mely az aggrekánhoz kapcsolódik.

A kollagének, a negatív töltésü proteoglikánok és egyéb fehérjék (link protein, COMP, fibronektin), illetve a kis proteoglikánok (decorin, biglikán, fibromodulin) közötti interakciók biztosítják a porcszövet terheléssel szembeni nyomó- és húzószilárdságát.

Más mátrix fehérjékhez kapcsolódva az ECM-ECM külcsönhatásokban adaptor szerepet töltenek be a matrilinek (ld. később).

\subsection{A matrilin család}

A matrilinek a szövetek sejtközötti állományában lévő nem-kollagénszerü fehérjék, amik a sejt-mátrix kölcsönhatások kialakításában és fenntartásában vesznek részt, 
biztosítva ezzel a szövet integritását és a mátrix olyan elrendeződését, amely lehetővé teszi a chondrocyta és más sejtek differenciálódását, valamint a csontfejlődést.

A matrilinek a különböző szövetek sejtközötti állományában kollagéntől függő és attól független finom hálózatokat alkotnak (1. ábra). Az ECM szerveződésében betöltött fontos szerepükre utal, hogy minden szövettípus sejtközötti állományában előfordul a család egy, vagy több tagja $[5,6]$.

A matrilin fehérjecsaládnak négy tagja van, melyeket közös moduláris szerkezetük alapján azonosítottak. Érett formájukban mindegyikben meghatározott számú epidermális növekedési faktor (EGF)-szerü domén kapcsol össze két von Willebrand faktor A (vWFA) domént, a C-terminálison pedig egy coiled-coil $\alpha$-helikális domén található, aminek az oligomerizációban van szerepe. Ettől az általános szerkezettől néhány esetben van eltérés. A matrilin-3-ban nincs meg a második vWFA domén, a matrilin-2 pedig tartalmaz egy egyedi domént a C-terminálison [5, 7].

A géncsalád tagjainak kifejeződése egymással részben átfed. A matrilin-1 és -3 csak a vázrendszerben expresszálódik, míg a matrilin-2 és -4 szélesebb szövetspecifitású, legjelentősebb mennyiségben a laza -és tömöttrostos kötőszövetekben fordulnak elő [5-7]. A matrilin-2 legmagasabb szinten a calvariában, az uterusban és a szívben fejeződik ki. Az endochondrális csontosodásban betöltött fontos szerepükre utal, hogy egérben a végtagfejlődés során a matrilin család mind a négy tagja expresszálódik [8].

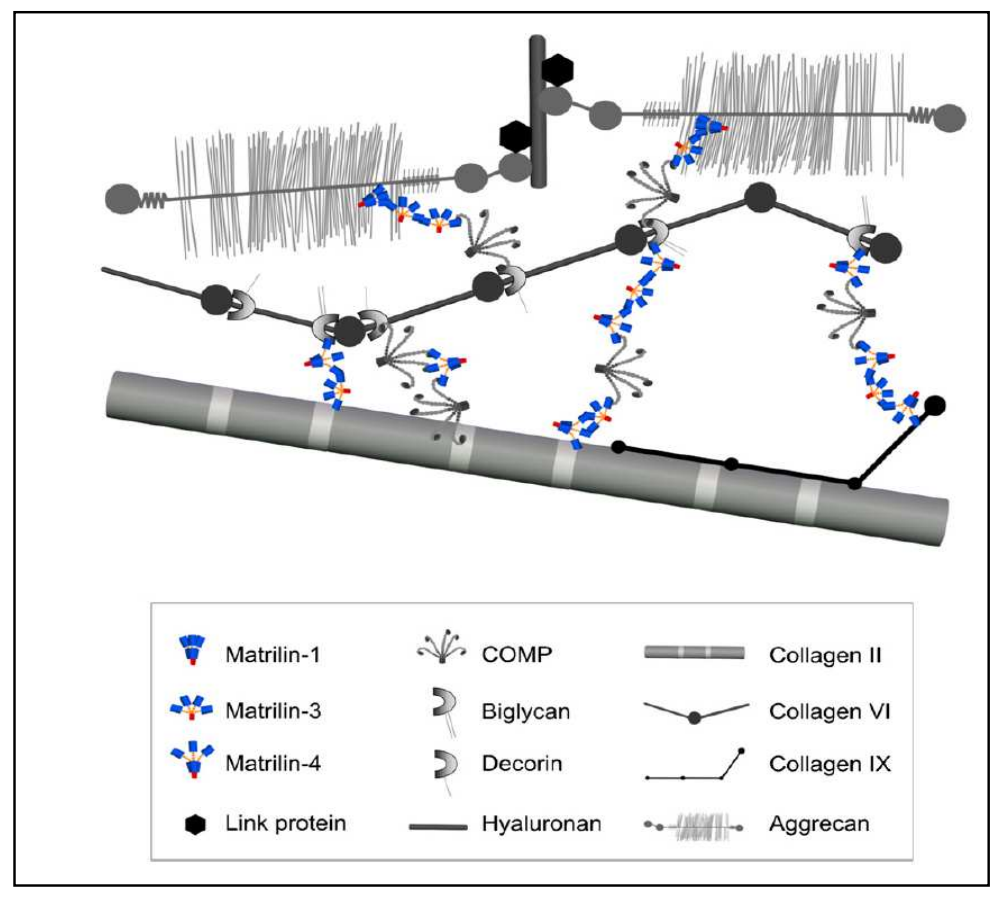

1. ábra A matrilinek adaptor szerepet töltenek be a porcszövet sejtközötti állományának felépítésében [7]. 


\subsection{A matrilin-1}

A matrilin-1/CMP (çartilage matrix protein) a fehérjecsalád elsőként azonosított tagja [9]. Először szarvasmarha légcső porcból tisztították. Specifikusan a porcszövetben fejeződik ki, de annak nem minden típusában. Így például nem figyelhető meg a nagy terhelésnek kitett ízületi porcban [10] és a csigolyaközti porcban sem. Ugyanakkor nagy mennyiségben fordul elő orr- és tracheaporcban. A matrilin-1 néhány egyéb szöveten kívül $[8,11]$ legnagyobb mennyiségben a hialinporcban fordul elő. Az expresszió mértéke függ a porcsejtek fejlődési stádiumától [12-14].

A matrilin-1 a nem kollagénszerü fehérjék csoportjába tartozik. Az 54 kDa tömegü monomer két vWFA doménből, egy EGF-szerű doménből és egy alfa-helikális coiled-coil doménből áll [15-17]. Az extracelluláris mátrix felépítésében diszulfid hidakkal stabilizált homotrimerként vesz részt, de más matrilinekkel heterooligomerek kialakítására is képes $[18,19]$.

A porcszövet extracelluláris mátrixában a matrilin-1 kapcsolódik az aggrekánhoz [20], a II. típusú kollagén rostokhoz [21], illetve az $\alpha 1 \beta 1$ integrinhez [22]. Ezt támasztja alá, hogy a matrilin-1 gén inaktiválása transzgenikus egerekben a kollagén rostképződés zavarát okozta [23], viszont ez nem vezetett rendellenes vázfejlődéshez, valószínüleg azért, mert a porcszövetben szintén jelenlévő matrilin-2 és -4 ellátja a matrilin-1 funkcióját [24]. A matrilin-1 a vWFA doménjein keresztül kollagénektől független hálózatok kialakítására is képes [25]. Ezekből az adatokból következik, hogy ez a fehérje adaptor funkciót tölthet be a mátrix szerveződésében.

Az endochondrális csontosodás folyamán a matrilin-1 gén a többi porcspecifikus markergénhez képest később kapcsol be. A késői proliferatív stádiumban lévő chondrocyták kezdik termelni, így e stádium jellemző markergénjének tekinthető $[12,14]$. In situ hibridizációs kísérletekben a matrilin-1 mRNS a fejlődő hosszú csontok növekedési korongjában zonális mintázatot mutat [26]. A kifejeződés mértéke a forrás porcsejtek zónájában alacsony szintű, a proliferatív és a felső hipertróf zónában a legnagyobb mértékű, míg az alsó hipertróf zónában egyáltalán nem figyelhető meg. 


\subsection{A porcos vázelemek képződése}

Gerincesekben a vázfejlődés konzervált, szigorúan szabályozott, egymással összefonódott morfogenetikai és szöveti differenciálódási lépések láncreakciójából áll. A gerincesek csontos vázelemei két úton fejlődnek ki. Intramembrán (desmogen), vagy endochondrális (chondrogen) csontosodással. Mindkét folyamat során az elkötelezett sejtek (osteochondroprogenitorok) az embrió meghatározott helyein kondenzálódnak és osteoblastokká, vagy chondrocytákká differenciálódnak.

Az intramembrán csontosodás során az osteoblastok, melyek a csontszövetre jellemző mátrixot termelik, közvetlenül a kondenzálódott mesenchyma sejtekből alakulnak ki. Így fejlődnek az agykoponya lapos csontjai és a kulcscsont [27,28].

Az endochondrális csontosodás során a kondenzálódott mesenchyma sejtekből egy átmeneti porcos váz fejlődik, ami a folyamat végére csonttá alakul. Ez jellemző a végtagok hosszú csontjainak, a bordáknak, a csigolyáknak és az arckoponya legtöbb csontjának kialakulására. Ez többlépcsős, rendkívül szigorúan szabályozott folyamat, melynek során jelentős morfológiai és génexpressziós változások zajlanak le. A differenciálódás folyamatát a Sox9 és két további porcspecifikus Sox faktor irányítja (ld. később). Minden differenciálódási stádiumban az adott állapotra jellemző markergének kifejeződése detektálható.

A porcdifferenciálódás első lépése a mesenchyma sejtek kondenzációja meghatározott helyen, időben és meghatározott sejtszámmal. Ebben a folyamatban olyan jelmolekulák szerepelnek, melyek indukálják a sejtadhéziót, gap junction kialakulást és a citoszkeletális váz átrendeződését [29]. A kondenzáció központjában levő sejtek előbb prechondrocytákká, majd chondroblastokká kezdenek fejlődni, amik intenzíven osztódnak és elkezdik termelni a porcszövetre jellemző mátrix fehérjéket (II., IX., XI. típusú kollagén, aggrekán, chondromodulin-1). A periférián levő néhány sejtréteg fibroblasztszerü perichondriális sejtté alakul.

A chondroblastok gyorsan osztódnak, korai és késői proliferatív stádiumokon keresztülhaladva végül hipertróf porcsejtekké differenciálódnak, melyek jellemző markereket kezdenek szintetizálni (X. típusú kollagén, osteopontin, MMP9, MMP13). Közben a perichondrium sejtjei és a hipertróf porcsejtek elkezdik termelni az angiogenezis stimulátorát is, a VEGF-et [30]. A következő lépésben a mátrix mineralizálódik, a perichondriumon keresztül kapillárisok lépnek a fejlődő csontba, amik az apoptózissal elhalt hipertróf sejteket eltávolító chondroclastokat és újabb differenciálatlan mesenchyma 
sejteket hoznak. Utóbbiak osteoblastokká alakulnak, amik a X. típusú kollagén előmintázaton csontos mátrixot raknak le, így végül a porcos váz elcsontosodik. A belépő myeloid eredetű sejtekből differenciálódó osteoclastok a csont folyamatos bontását végzik [28]. Az epifízeális porcok felszíni rétege azonban nem fejlődik csonttá, hanem ízületi porcként funkcionál életünk végéig.

Az epifízeális porc és a csontok hosszanti növekedése a felnőtt kor eléréséig egy speciális porcos struktúrához köthető, amit növekedési korongnak nevezünk. Az itt lévő chondrocyták morfológiailag és metabolikusan is elkülöníthető zónákba rendeződnek, melyek megfelelnek az embrionális porcfejlődési stádiumoknak [31] (2. ábra). A zónák egymáshoz viszonyított mérete fajonként eltérő [32,33]. A diafízistől legtávolabb eső sejtek alkotják a forrás (source) chondrocyták zónáját. Ezek a sejtek kicsik, azonos alakúak és gyorsan osztódnak. A következő zónát az oszlopos proliferatív porcsejtek alkotják, ezek lassabban osztódnak, oszlopokba rendeződnek és matrilin-1-et termelnek. Az osztódás intenzitása az oszlopokon lefelé haladva csökken.

A proliferációt követően a sejtek egy átmeneti prehipertróf zónába rendeződnek.

Az epifízis-diafízis határhoz legközelebb eső, nagyobb méretű, szabálytalan alakú chondrocyták alkotják a hipertróf zónát, melynek sejtjei rendkívül fontos szerepet töltenek be a növekedési korong struktúrájának fenntartásában és a csontosodási folyamatok szabályozásában azáltal, hogy a szomszédos szövetekben osteogenezist indukálnak szekretált faktorok és sejt-sejt kapcsolatok módosítása révén [34,35].

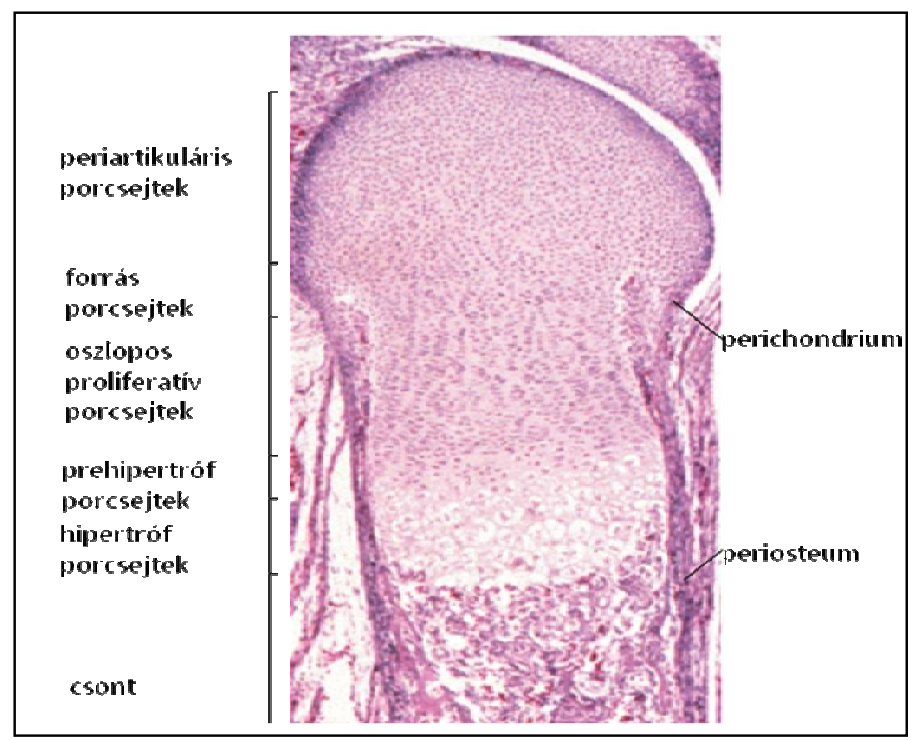

2. ábra A hosszú csontok növekedési korongjának felépítése. A forrás porcsejtek zónáját kisméretü, gyorsan osztódó sejtek alkotják. A proliferatív zónában a sejtek lassabban osztódnak, oszlopokba rendeződnek. A proliferációt követően a sejtek egy átmeneti prehipertróf zónába rendeződnek. A hipertróf zónát nagyobb méretű, szabálytalan alakú chondrocyták alkotják [129]. 


\subsection{A chondrogenezist és a csontok hosszanti növekedését szabályozó fontosabb jelátviteli utak}

A porcképződést transzkripciós faktorok és különböző növekedési faktorok szoros együttmüködése szabályozza. A porcdifferenciálódás fö transzkripciós faktora a Sox9, ami bekapcsolja a Sox5, Sox6 géneket, melyekkel együtt irányítja a porcfejlődés folyamatát a hipertróf stádiumig. A porcdifferenciálódást és a csontok hosszanti növekedését azonban más jelátviteli út befolyásolja. A csontok hosszanti növekedésében a növekedési korong zónáin áthaladó porcsejtek játszanak szerepet. A növekedés mértékét a prehipertrófból a hipertróf stádiumba átlépő sejtek száma határozza meg, melyek helyére majd osteoblastok lépnek. A növekedési korong zonális szerkezetét az alábbi jelátviteli utak tartják fenn.

A PTHrP (parathyroid hormone-related peptide) a perichondriális sejtekben, az ízületi felszínen az epifízeális porcsejtekben és a korai proliferatív chondrocytákban expresszálódik [36]. Receptora (PPR) a proliferatív chondrocytákon kis számban expresszálódik, de az oszlopos porcsejtzónán lefelé haladva a receptorok száma egyre nő. A PTHrP a porcsejteket proliferatív stádiumban tartja, megakadályozza a hipertrófiát [37], behatárolva ezzel azoknak a sejteknek a számát, amelyek Ihh-t expresszálnak. A prehipertróf zónában termelődő Ihh fokozza a PTHrP termelődését a periartikuláris régióban. Így az Ihh a PTHrP-vel negatív visszacsatoláson keresztül szabályozza a porcsejt differenciálódás mértékét. Csak a PTHrP termelődés helyétől legtávolabb eső sejtek tudnak a gátlás alól felszabadulni, prehipertróf stádiumba lépni és Ihh-t termelni, mely fenntartja a PTHrP expressziót [38].

A PTHrP receptorokat érintő mutációk mindegyike súlyos fejlődési rendellenességekkel jár. Ilyen például a Blomstrand chondro-osteodisztrófia, ahol a megrövidült végtagok idő előtti csontosodást mutatnak. A betegség minden esetben születés előtti halálhoz vezet [39]. A PTHrP receptorok folyamatos aktivációja Jansen-féle metafízeális diszpláziát okoz, melynek során a megrövidült végtagokban a porcsejtek nem hipertrofizálnak [40]. Az Ihh gén mutációja emberben A1 típusú brachydactíliát okoz, melyet alacsony testmagasság és megrövidült ujjpercek jellemeznek [35].

Szerepet játszanak még a chondrogenezisben az FGF (fibroblast growth factor) család tagjai és receptoraik. Az eddig azonosított 22 FGF ligand és 4 FGF receptor közül a porcfejlődés minden stádiumában kifejeződik valamelyik, bár szerepük nem minden folyamatban tisztázott [41]. Közülük legfontosabb az FGFR3, melyet föként a proliferatív 
és a korai hipertróf porcsejtek expresszálnak. Ezt a receptort több FGF ligand is képes aktiválni, de a növekedési korongban ezek közül az FGF18 a legjelentősebb [42]. A receptor működése többek között olyan jelátviteli utakat aktivál, melyeknek eredményeképpen a Stat1 transzkripciós faktor foszforilálódik, így növeli a p21 sejtciklus inhibitor expresszióját, emiatt a porcsejtek proliferációjának mértéke csökken és továbblépnek a hipertróf stádiumba [29,42].

Az FGFR3 gént érintő mutációk a receptor folyamatos aktivációjához vezetnek, ami emberben a végtagrövidülések különböző formáit okozza. Ezek közül a legismertebb az achondroplasia $[42,43]$.

A BMP-k (Bone Morphogenetic Proteins), melyek a TGF $\beta$ (transforming growth factor $\beta$ ) család tagjai, minden fejlődési folyamatnak fontos résztvevői. A BMP2, -4, -7 együttműködve szabályozza a mesenchyma sejtek kondenzációját és az ízületek kialakulását, illetve később a hosszúcsontokban többek között a BMP-k szabályozzák a porcsejtek érését és terminális differenciálódását. Hatásukra megnő a proliferáció mértéke, így a vázelemek mérete növekszik [44,45]. A BMP jelátviteli út több ponton antagonistaként hat az FGF jelátviteli utakra [46], az Ihh/PTHrP visszacsatolási hurkot pedig azáltal befolyásolja, hogy az Ihh expresszióját indukálja [47].

A mesenchyma sejtek kondenzációját szabályozó egyik fontos jelátviteli út a Wnt/ß-catenin út. A Wnt jelátviteli út aktivációjának hatására az addig foszforilált állapotban lévő $\beta$-catenin stabilizálódik és a sejtmagba transzportálódik, ahol gátolja a Sox9, a chondrogenezis fő regulátorának (ld. később) expresszióját, megakadályozva ezzel a porcfejlődést $[48,49]$. Ugyanennek az útnak a chondrogenezis későbbi szakaszaiban is fontos szerepe van, hiszen a porcsejtek proliferációját és hipertróffá alakulását szabályozza együttmüködve az Ihh jelátviteli úttal [50,51].

Az említetteken kívül számos más faktor is részt vesz a porcdifferenciálódás szabályozásában, melyek egymással kölcsönhatva alakítják ki a vázelemeket.

\subsection{A vázfejlődés morfogenetikus szabályozása}

A vázfejlődés során a szöveti differenciálódás a morfogenetikus szabályozás függvényében történik. A képződő vázelemek számának, méretének és 3-dimenziós alakjának meghatározása megelőzi a morfológiai megjelenésüket. A morfogenetikai szabályozás a végtagváz esetében a legismertebb. A gerincesek végtagjai a laterális lemez mezodermából alakulnak ki az embrióban. A szabályozási mechanizmusok, melyek a 
mesenchymális progenitor sejteket kifejlett végtag elemekké alakítják három tengely mentén hatnak: proximo-disztális (PD), a válltól az ujjak irányába; anterior-poszterior (AP), a hüvelykujjtól a kisujj irányába; dorzo-ventrális (DV), a kézfejtől a tenyér irányába. A végtagok három doménből állnak, melyek különböző struktúrákat tartalmaznak. A stylopodium tartalmazza a humerust, illetve a femurt, a zeugopodium a radiust és ulnát, illetve a tibiát és fibulát, az autopodium pedig a középcsontokat és az ujjakat [52].

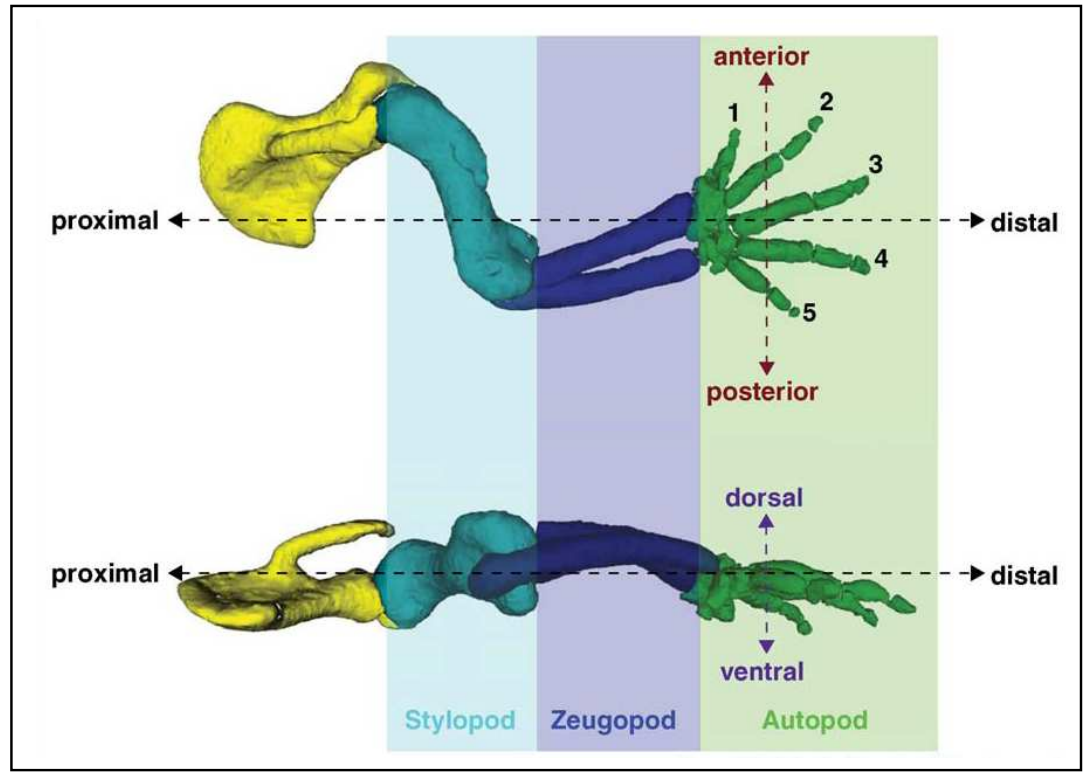

3. ábra A végtagfejlődés három tengely mentén történik. A proximo-disztális tengely a válltól az ujjakig, az antero-poszterior tengely a hüvelykujjtól a kisujjig, a dorzo-ventrális tengely a kézfejtől a tenyér irányába mutat. A végtagok három doménből állnak: a stylopodium tartalmazza a humerust, illetve a femurt, a zeugopodium a radiust és ulnát, illetve a tibiát és fibulát, az autopodium pedig a középcsontokat és az ujjakat [51].

A végtagfejlődést három fő szignalizációs központ szabályozza. Az apikális ektodermális gerinc (ㅁpical Ectodermal Ridge, AER) a végtagbimbó disztális részén az ektoderma magvastagodása, ahol proliferatív, differenciálatlan sejtek helyezkednek el, melyek a végtagbimbó PD irányú fejlődését biztosítják. Ennek a szignalizációs központnak a működését föként négy FGF szabályozza: FGF4, 8, 9, 17. Ezek mellett a BMP és wnt család több tagja is termelődik ebben a régióban. Egy újabb modell szerint a végtag mesenchyma sejtek elsődlegesen a proximális irányt meghatározó jelet kapnak a laterális mezodermából, ami valószínủleg a retinasav (RA), mely a Meis homeobox transzkripciós faktorok aktiválásán keresztül valósítja meg a proximális struktúrák (stylopodium) kialakítását [53]. Ezután az AER-ből érkező ellentétes FGF szignál hatására alakulnak ki a disztális struktúrák (autopodium). A zeugopodium struktúrái sejtkapcsolatok kialakulásával fejlődnek ki a proximális és disztális domének határán. 
A polarizációs zóna (Žone of Polarizing Acctivity, ZPA) a végtagbimbó disztális, poszterior részén lévő sejtek csoportja, mely a Sonic hedgehog (Shh) morfogént szekretálja, amely az AP tengely mentén történő fejlődés (az ujjak kialakulása) fő szabályozója. A ZPA-ban történő Shh expresszióhoz a Hoxb8 és az 5' HoxD gének (HoxD10-13) aktivációja szükséges [54]. Később az autopodium morfogenezise során e gének expressziója Shh függővé válik [55]. Az Shh úgy fejti ki hatását, hogy az AP tengely mentén grádienst képez. Azok a sejtek, melyek magas Shh koncentrációnak vannak kitéve poszterior struktúrákat alakítanak ki, míg az Shh forrástól távolabb lévő sejtekből anterior struktúrák lesznek. Az ujjak kialakulásában nem csak az Shh koncentrációjának van kritikus szerepe, de annak is, hogy a sejtek mennyi ideig vannak kitéve az Shh hatásának [56].

Az Shh és az FGF útvonalak között egy pozitív feedback loop alakul ki, melynek során az Shh hatására az FGF8 folyamatosan termelődik, ami indukálja és fenntartja az FGF4, 9 és 17 expressziót, míg az FGF jelátviteli út az Shh expressziójának fenntartásához szükséges [57].

Klasszikus embriológiai kísérletekkel azonosítottak egy szignalizációs központot a dorzális ektodermában, melynek a végtagbimbó DV tengelyének kialakításában van kulcsszerepe. Itt Wnt7a termelődik, mely a wnt útvonalon keresztül szabályozza az Lmx1b LIM homeobox gén expresszióját, melynek a dorzális struktúrák kialakításában van szerepe [58].

A dorzális ektoderma és a ZPA jelátviteli útjai között is van kapcsolat, mivel a Wnt7a szükséges a normál Shh expressziós szint fenntartásához [59].

\section{AZ EUKARIÓTA GÉNEK TRANSZKRIPCIÓS SZABÁLYOZÁSA}

\subsection{Az eukarióta génexpresszió szabályozásának lehetőségei}

A génexpresszió szabályozásának legmagasabb szintje a kromatin szintjén történő szabályozás. Eukariótákban a transzkripció templátja nem a szabad DNS, hanem a kromatin. Ennek ismétlődő egységei a nukleoszómák, melyekben 145-147 bp-nyi DNS tekeredik fel egy hiszton oktamerre, mely a core hisztonokból (H2A, H2B, H3, H4) kétkét molekulát tartalmaz. A nukleoszómák közötti linker DNS-hez a H1 hiszton kötődik.

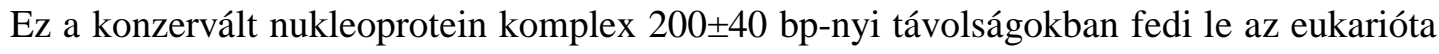


genomot [60,61]. Eukariótákban két mechanizmus van, ami a kromatint hozzáférhetővé teszi a transzkripciós faktorok és kofaktoraik számára. Kromatin módosító és kromatin remodeling komplexek. A kromatin módosítások a hisztonokon történő poszttranszlációs módosítások, melyek általában a hisztonok $\mathrm{N}$-terminális régióját érintik (acetiláció, metiláció, foszforiláció, ubiquitináció, sumoyláció, ADP-riboziláció) [62]. A módosításokat enzimkomplexek végzik, közülük legjobban jellemzettek a hiszton acetiltranszferázok (HAT). A folyamat reverzibilis, az acetil csoportok eltávolítását a hiszton deacetilázok (HDAC) végzik. A hiszton remodeling komplexek közös tulajdonsága, hogy a nukleoszómák elmozdításához ATP hidrolíziséből nyerik az energiát [63].

A génszabályozás második szintje a transzkripció szintjén történő szabályozás. Ez a nyitott kromatin régiókon megy végbe és lehetővé teszi az eukarióta gének szövetspecifikus és fejlődési stádiumspecifikus kifejeződését egy előre meghatározott program szerint. Ezt a programot különböző transzkripciós faktorok (transz faktorok) irányítják, amelyek a DNS specifikus szakaszaihoz (cisz elemek) kötődnek azon gének környezetében, melyeknek müködését szabályozzák. Együttmüködésük biztosítja, hogy a megfelelő gén promotere hozzáférhető legyen a transzkripciós apparátus számára.

Amikor a transzkripciós komplex összeszerelödik, az RNS polimeráz II (polII) Cterminális doménje foszforilálódik, elindul a transzkripció. Az elongációt a polII aktivitásának szabályozásával több faktor irányítja [64].

A kromatin- és transzkripció szintű szabályozás mellett lehetőség van még a génexpresszió szabályozására a splicing és a transzláció szintjén is.

\subsection{A transzkripciós szabályozásban résztvevő fontosabb fehérje komponensek}

Az általános transzkripciós faktorokon (TFIIA-J) és asszociált faktorokon (TAF) kívül a transzkripciós szabályozás fontos résztvevői a tulajdonképpeni transzkripciós faktorok. Ezek általában nagy affinitással, szekvencia-specifikusan kötődnek a DNS nagy árkába. A transzkripciós faktorok moduláris felépítésüek, többségük rendelkezik DNS-felismerő és kötő, dimerizácós és transzaktivációs doménnel is. A DNS-kötő domének lehetnek Znfinger, helix-loop-helix, Leu-zipper, vagy homeodomén motívumok. Ilyen tulajdonképpeni transzkripciós faktorok például az NFI, IL1 és Hox faktorok. Ezek általában kooperatívan kötődnek a szabályozó régiókhoz. Több fehérje-fehérje interakcióra van szükség ahhoz, hogy a szabályozó fehérjék a megfelelő affinitással kötődjenek a megfelelő DNS szakaszhoz. Az enhancereken kialakuló olyan nukleoprotein 
komplexeket, melyeket a transzkripciós faktorok, aktivátoraik és a szerkezeti fehérjék alkotnak, enhanceoszómáknak nevezzük.

Az említett faktorokon kívül a transzkripciós szabályozásban szerepet játszanak még a hisztonok és a nem-hiszton kromatin komponensek. Utóbbiak közül a HMG (High Mobility Group) szupercsalád kiemelkedő jelentőségű. Három fehérjecsalád tartozik ide: HMGA (HMG-AT hurok), HMGN (HMG-nukleoszóma-kötő) és HMGB (HMG-box). A különböző HMG családok tagjai a legtöbb eukarióta sejtben kifejeződnek, változatos funkciókat látnak el. Különböző struktúrájú, egyedi DNS-kötő motívumokat tartalmaznak. A HMGB családba tartozó összes fehérje rendelkezik DNS-kötő doménnel (HMG-box), de nincs transzaktivációs doménjük. Nem szekvencia-specifikusan a DNS kis árkába kötődnek, ezzel meghajlítva azt [75].

Vannak a HMG fehérjék és a tulajdonképpeni transzkripciós faktorok közötti átmeneti tulajdonságokkal rendelkező transzkripciós faktorok is. Ilyenek a Sox család tagjai, melyek HMG doménjükkel kis szekvencia-specifitással és kis affinitással kötődnek a DNS kis árkába. Egyes Sox fehérjék rendelkeznek transzaktivációs doménnel is, ilyen például a chondrogenezis fö regulátora, a Sox9 (ld. később).

Az RNS polimeráz II a számos alegységével és aktivitását szabályozó több faktorral az eukarióta transzkripció motorja [64].

\subsection{A transzkripciós szabályozásban résztvevő DNS elemek}

A core promoter a gének transzkripciós start helye (+1) körüli régió, amely egy, vagy több felismerő helyet tartalmaz a szabályozó fehérjék részére. E fehérjék kötődése szükséges a preiniciációs komplex (PIC) összerendeződéséhez. A legismertebb ilyen szekvencia a TATA-box, egy konszenzus AT gazdag régió, ami kötőhelyet biztosít a TBP (TATA-kötő fehérje) részére [65]. Ez a transzkripciós startpont előtt 25-30 bázispárral helyezkedik el, biztosítva, hogy a transzkripció pontosan a +1 pozícióban induljon el. A TBP a TAF-okkal (TBP asszociált faktorok) együtt alakítja ki a több alegységből álló iniciációs komplexet, a TFIID-t. A TFIID kötődése a TATA boxhoz az első lépése a stabil transzkripciós komplex kialakulásának. Más általános transzkripciós faktorok (TFIIA-J) és az RNS polimeráz II kötődésével alakul ki a PIC [66].

A TATA boxon kívül más DNS elemei is vannak a core promotereknek. Ilyenek az Inr (initiator element), DPE (downstream promoter element), BRE (TFIIB recognition elemet). Alacsonyabbrendüek core promoterében egyetlen transzkripciós starthely van, 
míg a magasabbrendü eukarióták core promotereire jellemzö, hogy több potenciális transzkripciós starthellyel rendelkeznek, melyek egy 50-100 bp-os szakaszon belül helyezkednek el $[67,68]$.

A TATA-boxtól 5' irányban - általában 40-110 bp távolságban - egyéb promoter elemek is találhatók, lehetnek általánosan előforduló aktivátorok felismerőhelyei. Ezek megléte nem jellemző minden génre, de ha jelen vannak, akkor a transzkripció intenzitását szabályozzák. Ilyenek például a CCAAT-box és a GC-box.

Vannak pozitív és negatív szabályozó elemek, melyek bizonyos távolságon belül, vagy pozíciójuktól függően aktiválják, vagy gátolják a promoter müködését.

Az enhancerek a transzkripciós starthelytől sokkal távolabb elhelyezkedő szabályozó régiók, amelyek a géntől mért távolságuktól és orientációjuktól függetlenül képesek nagyságrendekkel megnövelni a promoter aktivitását. Elhelyezkedhetnek exonban, intronban, az 5' és 3' nem transzlálódó régiókban. Egér és humán szövetspecifikus enhancerekre jellemző, hogy akár 100 kbp távolságra is elhelyezkedhetnek a génhatároktól [69]. Müködésükre jellemző, hogy bizonyos enhancerek a TATA boxot tartalmazó promotereket preferálják, mások viszont a DPE tartalmúakat [70].

Az enhancerek szekvenciája a halaktól az emlősökig rendkívül konzervált, jelentőségüket $\mathrm{az}$ is jelzi, hogy bizonyos betegségek kialakulásában az enhancer szekvenciákban bekövetkező deléciók, mutációk játszanak szerepet. Ilyen például a vázfejlődés szabályozásában kulcsfontosságú Shh gén regulátorában, a ZRS (ZPA regulatory sequence) végtagspecifikus enhancerben bekövetkezett pontmutáció, amely preaxiláris polydactiliát okoz $[71,72]$.

A silencerek az enhancerekkel ellentétes müködésü reguláló elemek, amelyek az adott gén kifejeződését távolságtól és iránytól függetlenül erőteljesen gátolják.

A silencer elemek rövid motívumok, melyek pozíciójuktól függetlenül, a hozzájuk kötődő represszor fehérjék által megakadályozzák a PIC összeszerelődését. Ezek általában a transzkripciós starthelytől 3'irányban helyezkednek el [66,73].

Az enhancerek és silencerek több gén működését is irányíthatják, de bizonyos esetekben ezek az interakciók nem kívánatosak. Kivédésükre alakultak ki az inzulátorok, melyek olyan cisz reguláló elemek, amik megakadályozzák, hogy a szabályozó régiók a szomszédos géneken is kifejtsék hatásukat. Az inzulátorok két módon müködhetnek. Ha az enhancer és a promoter között helyezkednek el, akkor direkt módon akadályozzák az enhancer-promoter komplex kialakulását. Ha az eu- és heterokromatin határokon 
helyezkednek el, akkor pedig akadályozzák a kromatin túlzott mértékủ átrendeződését [74].

\subsection{A transzgenikus állatmodellek szerepe az eukarióta génreguláció tanulmányozásában}

A transzgenikus technikák lehetőséget kínálnak többek között a génreguláció és a sejtdifferenciálódás tanulmányozására, szövet- és fejlődési állapotspecifikus szabályozó elemek in vivo azonosítására, valamint humán genetikai betegségek modellezésére emlős rendszerekben. A leggyakrabban használt modell állat az egér, mivel rövid a generációs ideje, viszonylag könnyen tartható, valamint a rendelkezésre álló transzgenikus technikák jelentős részét egérben írták le.

Transzgenikus állatok előállítása többféle módszerrel lehetséges.

A rekombináns DNS technikával előállított DNS vektorok mikroinjektálással való direkt bejuttatása megtermékenyített petesejtek hím előmagjába az egyik elsőként leírt [76], leginkább elterjedt és sikeres módja a transzgenikus állatok előállításának. Ez a rendszer lehetővé teszi a bejuttatott konstrukció hatásának tanulmányozását a normál embrionális fejlődés során. Az injektáláshoz linearizált DNS-t használnak, amit előzőleg baktériumokban szaporítanak fel. A rekombináns DNS-ből általában több kópia jut be, ezek legtöbbször együtt, fej-láb elrendeződésben integrálódnak a genomba. A kromoszómán az integrációs helyet a véletlenszerủen létrejövő kromoszómális törések szolgáltatják. A beépülés a kromoszómaszerkezetben átrendeződéseket, deléciókat, duplikációkat, inverziókat is okozhat, így az integrálódás helye módosíthatja a kifejeződési mintázatot. Hasonló hatású lehet, ha erős promoter/enhancer, illetve represszor környezetébe integrálódik a transzgén. Létfontosságú génbe való beépülés fenotípusváltozást okozhat, vagy inszerciós mutáció lehet a következménye, ami több biológiai funkciót is befolyásolhat, vagy embrióhalált okozhat [76]. A pozíció effektusok kiküszöbölésére a transzgén konstrukciókba célszerü inzulátor szekvenciákat építeni. A genomi környezetből adódó hatásokat pedig megfelelő számú alapító embrió, illetve az azokból létrehozott transzgenikus vonalakból származó állatok vizsgálatával detektálhatjuk.

Általában jellemző, hogy a transzgénben jelenlévő intronok növelik az expresszió szintjét [77], mivel ezek jelenléte lehetővé teszi a transzgén splicing-ját, ami stabilabb mRNS 
kialakulását és az RNS hatékonyabb transzportját eredményezi a sejtmagból a citoplazmába [130].

Korlátai ellenére a pronukleusz mikroinjektálás egyszerűbb és gyorsabb módja a reguláló régiók müködésének in vivo vizsgálatára, mint az ES sejtekben történő homológ rekombináción és blasztociszta injektáláson alapuló, költségesebb módszer.

\section{A PORCSPECIFIKUS GÉNEXPRESSZIÓ TRANSZKRIPCIÓS SZABÁLYOZÁSA}

\subsection{A Sox-trió}

A porcfejlődésben szerepet játszó transzkripciós faktorok közül a legfontosabbak a HMG (high mobility group) domént tartalmazó Sox (ㅁry-related HMG box ) család tagjai.

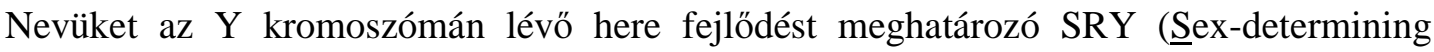
region on $\underline{Y}$ chromosome) fehérje után kapták. Azok a transzkripciós faktorok tartoznak ebbe a családba, amelyek HMGB doménje legalább 50\%-os homológiát mutat a SRY HMGB doménjével. Az ide tartozó transzkripciós faktorokat szekvencia homológia alapján emberben és egérben nyolc alcsoportba lehet osztani [78].

A tipikus transzkripciós faktorokkal ellentétben a Sox fehérjék a DNS kis árkába gyengén kötődve hajlítják meg azt. A kötődés kis szekvencia specificitású, konszenzus felismeröhelyük a következő: 5'-(A/T)(A/T)CAA(A/T)G-3' [78,79].

A chondrogenezis szempontjából kiemelkedően fontos Sox faktorok az ún. Sox trió tagjai: A Sox5/L-Sox5 és Sox6 a D csoportba tartoznak, nem rendelkeznek transzaktivációs doménnel, inkább a transzkripciós komplexek szerkezetének kialakításáért felelősek.

A Sox9 az E csoport tagjaként rendelkezik transzaktivációs doménnel, transzkripciós faktorként direkt szerepe van több porc mátrix fehérjét kódoló gén, többek között a matrilin-1 gén szabályozásában is [80].

A Sox-trió tagjai közül a Sox9 a porcképződés fő regulátora, de más szervek, szövetek (hím nemi szervek, szív, oligodendrociták) embrionális fejlődése során is jelentős a szerepe [81,82]. A porcfejlődés során már az elkötelezett osteochondroprogenitorokban expresszálódik és a mesenchyma sejtek kondenzációjától egészen a prehipertróf stádiumig aktív. Emberben a Sox9 gén haploid mutációja campomelic displasiat okoz, mely a hosszú csontok abnormális görbületével és egyéb fejlődési rendellenességekkel jár [83]. Egérben 
heterozigóta Sox9 mutánsok a campomelic displasiahoz hasonló vázfejlődési rendellenességeket mutatnak, a mesenchyma sejtek kondenzációja nem, vagy késve megy végbe, a hipertróf zóna kiterjedtebb, a porc idő előtt mineralizálódik [84,85]. További „loss-of-function” és „gain-of-function” mutánsok vizsgálata során bebizonyosodott, hogy a Sox9-nek nem csak az osteochondroprogenitorok elköteleződésében és a mesenchyma sejtek kondenzációjában van szerepe, hanem a porcsejtek osztódásában, érésében a hipertróf stádium eléréséig [82].

Annak ellenére, hogy a Sox9 a porcfejlődés fö regulátora, szabályozásának pontos mechanizmusa még nem ismert. Több kísérleti rendszerben azonban kimutatták, hogy a chondrogenezisben szerepet játszó bizonyos jelmolekulák a Sox9 szabályozói transzkripciós, illetve fehérje szinten is.

Mesenchyma és chondrocyta sejtekben több FGF ligand is jelentősen megnöveli a Sox9 kifejeződési szintjét a MAPK jelátviteli úton keresztül [86].

A Sox9 két konszenzus foszforilációs helyet tartalmaz a cAMP-függő protein kináz A (PKA) számára. A foszforiláció megnöveli a fehérje DNS-kötő kapacitását és transzkripciós aktivitását [87]. Mivel a PKA a PTHrP jelátviteli út egyik komponense, valószínü, hogy a Sox9 a PTHrP út egyik célmolekulája. Ezt támasztja alá az az eredmény is, hogy a H89, ami a PKA specifikus inhibitora, gátolja a Sox9 foszforilációját [87].

Az IL1 és a TNF $\alpha$ gátolják a Sox9 gén expresszióját. Ezt a hatásukat valószínủleg az NFkB úton keresztül érvényesítik [88], ahogy azt humán csigolyaközti porckorongokból izolált sejtek esetében tapasztalták in vitro kísérletekben [89].

Leírták továbbá, hogy a Sox9 a CBP/p300 (Creb-binding protein) komplexhez kapcsolódva kötődik a Col2al gén enhanceréhez, aktiválva ezzel a transzkripciót [90].

Ezek az adatok is azt támasztják alá, hogy a Sox9 a porcfejlődés szabályozásában nélkülözhetetlen.

A chondroblastok differenciálódásához és a növekedési korong zonális szerkezetének kialakulásához a Sox9-en kívül L-Sox5/Sox6-ra is szükség van. Hiányukban nem aktiválódik a matrilin-1 gén és csökken a többi porcfehérje gén ( $A g c$, Crtll) expressziós szintje is.

Az L-Sox5 (a Sox5 hosszabb izoformája) és Sox6 gén kifejeződési mintázata a porcfejlődés során nagymértékben átfed a Sox9 génével [91]. Ezen gének külön-külön kiütése kisebb vázrendszeri eltéréseket okoz, viszont mindkét gén együttes kiütése általános chondrodysplasiához vezet [92]. 


\subsection{A Sox-trió által szabályozott porc mátrix fehérjéket kódoló gének}

A Sox-trió több porc mátrix fehérjét kódoló gén szabályozásában fontos résztvevő. A Sox9 az N-terminális HMGB doménjein keresztül homodimerként, míg a Sox5, Sox6 az N-terminális coiled-coil doménjein keresztül homo-, illetve heterodimerként kapcsolódik a kötőhelyeihez [93,94].

A Col2a1 gén porcspecifikus szabályozó régiójának első intronjában azonosítottak egy 48 bp hosszúságú enhancer elemet, amelynek jelenléte elégséges feltétele a gén porcspecifikus expressziójának [95]. Ez az enhancer elem négy Sox kötőhelyet tartalmaz, melyen keresztül a Sox-trió más transzkripciós faktorokkal együttmüködve aktiválja a Col2al müködését [96].

A Col9a1 gén enhancer elemében négy Sox konszenzus motívumot azonosítottak, melyek kettesével rendeződnek párokba. Ezekhez két Sox9 dimer kötődése szükséges a transzkripció aktiválásához [97].

Hasonló HMGB domén kötőhelyeket találtak a Col11a2 gén promoterének 5' régiójában, melyekről szintén kiderült, hogy képesek Sox9-cel (és egyéb faktorokkal) transzkripciós komplexet létrehozni, mely porcspecifikus expressziót eredményez [98].

A legutóbb felfedezett kollagén, a Col27a1 gén enhancer elemében szintén találhatók Sox9 kötőhelyek, melyek aktív szerepet játszanak a gén transzkripciós szabályozásában [99].

A kollagéneken kívül más mátrix fehérjéket kódoló gének szabályozásában is részt vesznek a Sox-trió tagjai. Ilyen például az aggrekán gén, melynek a 4,5kb-os első intronja tartalmaz Sox9 kötőhelyeket [100]. A CD-RAP (cartilage-derived retionic acid-sensitive protein) gén promoterében szintén található Sox konszenzus motívum, melyhez a Sox9 kötődése aktiválja a transzkripciót [101].

Ezen gének Sox faktorok által történő szabályozásának közös vonása, hogy a Sox kötőhelyek minden esetben több kópiában, ellentétes orientációban helyezkednek el, hozzájuk a Sox9 mindig dimer formában kötődik. Számos kísérlet támasztja alá, hogy a Sox9 dimerizációjára csak a chondrogenezis szabályozásában van szükség, míg a nemi jelleg kialakításában szerepet játszó két ismert gén, az SF1 (Steroidogenic Factor 1) és az $A M H$ (anti-Müllerian hormon) esetében a Sox9 monomer formában kapcsolódik az egy kópiában jelen lévő kötőhelyéhez [102]. 


\subsection{A matrilin-1 gén szerkezete és transzkripciós szabályozása}

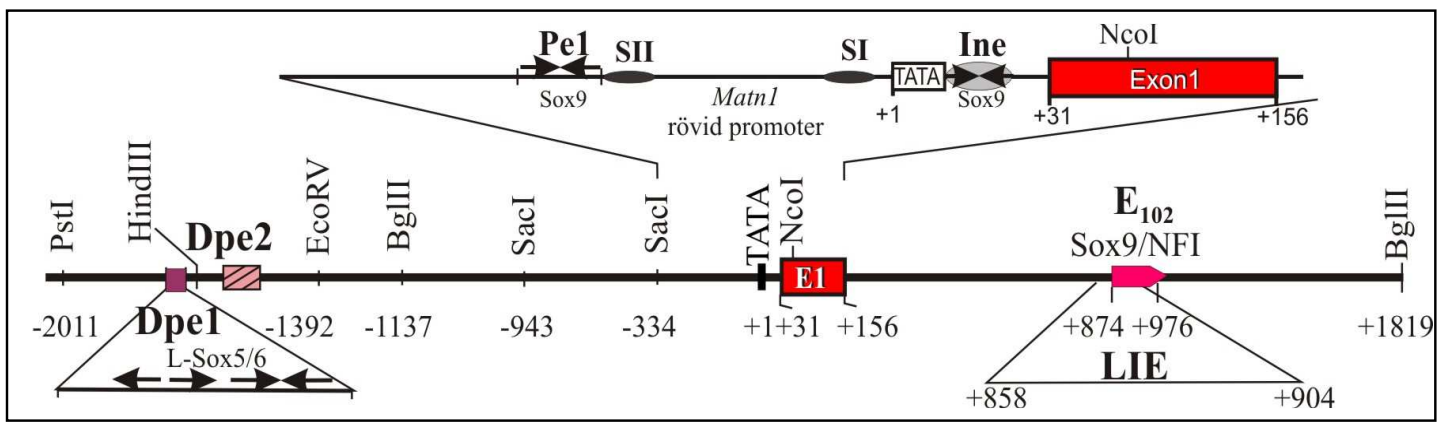

4. ábra A csirke matrilin-1 gén szabályozó elemei és a hozzájuk kötődő transzkripciós faktorok. Dpe1 és Dpe2, disztális promoter elemek; $\mathrm{E}_{102}, 102$ bp-os introni elem; Ine, iniciátor elem; LIE, introni elem; Pe1, proximális promoter elem; SI és SII, silencer elem I és II.

Csoportunk korábbi kísérletekben már felderítette a csirke matrilin-1 gén szerkezetét és fő szabályozó régióit. Ez a gén a csirke genomban egy kópiában található meg. 18 kb hosszúságú, nyolc exonból és hét intronból épül fel [103]. A génnek két transzkripciós startpontja van, amik egymástól nyolc bp távolságra helyezkednek el. A promoter régióban egy CAT- és egy TATA-szerủ szekvencia (TTAATA) található. A TATA-box és annak közvetlen környezete szövetspecifikusan müködik, tranziens expressziós kísérletekben CAT riporter gén elé építve minimálpromoterként funkcionál, mely fibroblasztokban is aktív [103].

Korábbi tranziens expressziós vizsgálatokból kiderült, hogy mind az első intron, mind pedig a hosszú promoter szakasz tartalmaz porcspecifikus szabályozó régiókat [104]. Mivel a gén minimál promotere viszonylag alacsony aktivitású, ezért valószínủnek látszott, hogy a transzkripció hatásfokának megnöveléséhez erős pozitív szabályozó elemek jelenléte szükséges. Ilyen porcspecifikus enhancer elemet azonosítottak az első intronban a +578 és +966 bázispárok között [104]. A matrilin-1 gén szabályozásában silencer elemek is közremüködnek. Ilyen régió található a gén promotere előtt 10.7 és 6.8 kb távolságban, amely chondrocyta-specifikusan müködik. A-334 és -15 helyzetü proximális promoter szakasz két negatív szabályozó elemet hordoz, melyek tranziens expressziós kísérletekben mind chondrocytákban, mind fibroblasztokban működnek és Nfi transzkripciós faktor kötőhelyeket tartalmaznak [105] (4. ábra).

Korábbi kísérletek azt mutatják, hogy a csirke gén transzgenikus egerekben is jellegzetes, szúkített porcspecifikus kifejeződést mutat és nem aktív a fiatal chondroblastokban [106]. A hosszú promoter egyedül, vagy az introni szakasszal együtt 
képes az endogén génre jellemző szövet- és fejlődési állapotspecifikus riportergén kifejeződést irányítani porcsejtekben. A legmagasabb szintű expresszió a növekedési korong proliferatív és prehipertróf zónáiban figyelhető meg. A rövid promoter az introni szakasszal együtt is képes hasonlóan szükített, porcspecifikus mintázatú, de sokkal kisebb aktivitású riportergén expressziót irányítani [107]. 


\section{CÉLKITÜZÉSEK}

A matrilin-1 gén egyedi tulajdonsága, hogy kifejeződése az endochondrális csontosodás során a növekedési korong proliferatív és prehipertróf zónáira korlátozódik. Ez olyan szabályozó mechanizmusokat feltételez, melyek hasonlóak, illetve különbözőek lehetnek más porc mátrix fehérjéket kódoló gének transzkripciós szabályozásától.

Kísérleteinkkel arra keressük a választ, hogy a gén korábban már azonosított szabályozó elemei közül melyik és milyen mértékben befolyásolja a szövet- és fejlődési állapotspecifikus kifejeződést, valamint hogy azonos, vagy különböző DNS szakaszok felelősek-e ezért a szabályozásért.

Ennek érdekében a következő kísérleti feladatok megvalósítását tüztük ki célul:

- A már korábban leírt szabályozó elemek különböző kombinációival riporter konstrukciók létrehozása. A konstrukciók aktivitásának meghatározása tranziens expressziós kísérletekben különböző sejtkultúrákban.

- Olyan konstrukciók kiválasztása, melyek hatással vannak a gén szövet- és fejlődési állapotspecifikus kifejeződésére.

- A szabályozásban részt vevő Sox faktorok kötődésének igazolása in vitro EMSA kísérletekben.

- A megfelelö DNS-elem kombinációkkal LacZ riporter konstrukciók készítése, melyekkel transzgenikus egereket hozunk létre, hogy hatásukat in vivo vizsgálhassuk.

- Az injektálásból származó alapító (F0), és a transzgenikus vonalakból származó embriókban a transzgén expresszió térbeli és időbeli vizsgálata hisztológiai módszerekkel.

- A fenti kísérletek alapján a különböző transzgének expressziós mintázatának összehasonlító vizsgálata és a mintázat kialakításáért felelős DNS elemek behatárolása.

- DNS elemekben pontmutációt hordozó LacZ konstrukciók létrehozása és a mutációk in vivo hatásának vizsgálata transzgenikus egerekben. 


\section{ANYAGOK ÉS MÓDSZEREK}

\section{Plazmid konstrukciók}

\subsection{Tranziens expressziós kísérletekhez használt plazmidok készítése}

A rövid (-334/+67), illetve a teljes hosszúságú (-2011/+67) matrilin-1 promoter által irányított luciferáz riporter gént tartalmazó konstrukciók (FO15Luc és AC8Luc) már rendelkezésünkre álltak [80].

A promoter rövidítési sorozathoz a matrilin-1 PstI-SacI (-2011/-948), PstIBglII(feltöltött) (-2011/-1134), PstI-EcoRI(feltöltött) (-2011/-1394), PstIHindIII(feltöltött) (-2011/-1741) promoter szakaszokat az FO15Luc vektor PstI-SacI, illetve PstI-SacI(feltöltött) helyeire a szokásos génsebészeti módszerekkel építettük be.

A Pe1M1, Pe1M4, IneM1, IneM2, IneM3 mutációkat tartalmazó rövid promoteres konstrukciók PCR-alapú mutagenezissel készültek (QuikChange, Stratagene), melynek templátja az FO15-Luc plazmid volt. A reakcióhoz a megfelelő pontmutációt hordozó oligonukleotidokat használtuk [80]. Az AC8Luc mutáns változatainak előállításához a megfelelő FO15-Luc konstrukciók rövid promoterét egészítettük ki a teljes hosszúságú promoterre [80].

A $8 x_{\text {Col2a1 }}$-FO15-Luc, $16 x E_{\text {Col2a1 }}$-FO15-Luc és a Dpe1 és Dpe2 elemeket különböző kombinációkban tartalmazó klónokat Dr. Kénesi Erzsébet készítette.

A $8 \mathrm{xE}_{\mathrm{Col2a1}}-8 \mathrm{xE}_{102}$-FO15-Luc konstrukcióhoz a $8 \mathrm{xE}_{\mathrm{Col2a1}}-\mathrm{FO} 15-\mathrm{Luc}$ plazmid SpeI(feltöltött)-SacI helyeire klónoztuk a 8xE $102-N A D 1$ vektorból SalI(feltöltött)-SacI enzimekkel kivágott $8 \mathrm{xE}_{102}$ fragmentumot.

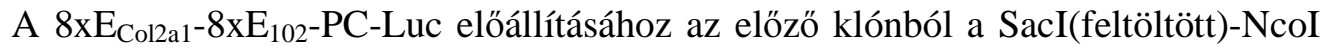
fragmentumot klónoztuk át az ApaI(feltöltött)-NcoI enzimekkel emésztett PC-Luc plazmidba, melyet úgy állítottunk elő, hogy az FO15-Luc plazmid NcoI-ApaI helyeire építettük a Col2al minimál promotert.

A $8 \mathrm{xE}_{\text {Col2a1 }}$-8xLIE KpnI-SmaI fragmentumot az ugyanígy emésztett FO15-be építve kaptuk meg a 8xE $\mathrm{Col2a1}_{1}$-8xLIE-FO15-Luc klónt.

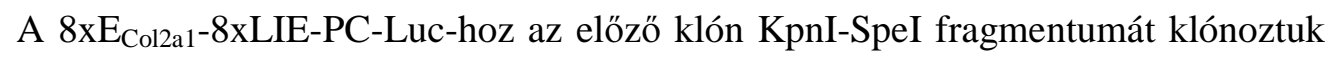
az ugyanígy emésztett $8 \mathrm{xE}_{\mathrm{Col} 2 \mathrm{a} 1}$-FO15-be.

Minden konstrukciót restrikciós emésztéssel és szekvencia analízissel ellenőriztünk. 


\subsection{Transzgenikus egerek előállításához használt plazmidok készítése}

A pozíciók a csirke matrilin-1 TATA motívumának első T nukleotidjától számítottak.

A NAD1 konstrukció előállításához a matrilin-1 gén -334/+67 rövid promoter szakaszát a pUC8CMP14nB/D szubklónból távolítottuk el KpnI(feltöltött)-NcoI emésztéssel, majd a pJB-AD vektor HindIII(feltöltött)-NcoI helyeire építettük. A pJB-AD vektort úgy készítettük, hogy a pJB-HRV vektor [107] NotI-NcoI helyeire ligáltuk a NotI, SalI, PstI, HindIII, BglII, NcoI polilinkert. A LacZ kazettát az SV40 nukleáris transzport szignál és az MP-1 poliadenilációs hely határolta.

A PS-NAD1 és PB-NAD1 vektorokat úgy készítettük, hogy a matrilin-1 -2011/948, illetve -2011/-1134 szakaszát a megfelelő luciferáz riporteres konstrukcióból SalI, illetve NotI-SalI emésztéssel klónoztuk át a megfelelően emésztett NAD1-be.

A $8 \mathrm{xE}_{\mathrm{Col2a} 1}-\mathrm{NAD} 1$ és $16 \mathrm{xE}_{\mathrm{Col2a} 1}-\mathrm{NAD} 1$ konstrukciókhoz a Col2al enhancer megfelelő számú kópiáit egy szubklónból vágtuk ki NotI-SalI emésztéssel és az ugyanígy emésztett NAD1 vektorba ligáltuk.

A $\Delta$ Pe1M4-TR70, $\Delta$ IneMI-TR70 és $\Delta$ IneM2-TR70 konstrukciókhoz a TR70 transzgén PstI-NcoI szakaszát cseréltük ki a megfelelő mutációt hordozó AC8-Luc konstrukciókból.

A 8xDpe1-NAD1 és a $\triangle$ Dpe2-NAD1 transzgéneket úgy állítottuk elő, hogy a luciferáz riportert tartalmazó konstrukciókból (8xDpe1-FO15Luc, illetve $\Delta \mathrm{Dpe} 2-\mathrm{FO} 15-$ Luc) KpnI(feltöltött)-PstI, illetve PstI-NcoI emésztéssel a megfelelő szakaszt kivágtuk és a NAD1 vektor SalI(feltöltött)-PstI, illetve PstI-NcoI helyeire építettük.

A PS-PC konstrukció előállításához a Col2a1 gén promoterét egy szubklónból távolítottuk el ApaI(feltöltött)-SmaI emésztéssel, majd a PS-NAD1 plazmid feltöltött PstINcoI helyeire építettük.

A 8xLIE-NAD1 készítéséhez a LIE elem négy kópiáját egy szubklónból ClaI(feltöltött)-XbaI emésztéssel eltávolítottuk és a SmaI-XbaI enzimekkel felnyitott 4xLIE-NAD1 vektorba klónoztuk.

A 4xE $102-N A D 1-h e z$ az enhancer elem négy kópiáját az azokat tartalmazó szubklónból SalI-SmaI emésztéssel vágtuk ki és a NAD1 SalI-PstI(feltöltött) helyeire építettük. 


\begin{abstract}
Minden konstrukciót restrikciós emésztéssel és szekvencia analízissel ellenőriztünk.
\end{abstract}

\title{
2. Transzgenikus egerek előállítása
}

A LacZ riporter gént tartalmazó konstrukciókat NotI-KpnI emésztéssel hasítottuk, a szabályozó régiókat és a LacZ gént tartalmazó fragmentumot elválasztottuk a vektortól. A tisztított fragmentumokat éjszakán át dializáltuk, majd mikroinjektálással juttattuk az egerek megtermékenyített petesejtjeinek hím előmagjába. Ehhez donorként 4-6 hetes, szuperovuláltatott (C57BL/6XCBA) F1 hibrid, illetve FVB nőstényeket használtunk (Charles River Laboratories, Magyarország). A túlélt zigótákat 2 hónaposnál idősebb, vazektomizált Swiss hímmel pároztatott, álvemhes CD-1 recipiens nőstényekbe ültettük (Charles River Laboratories, Magyarország). A pronukleusz mikroinjektálást Dr. Sinkó Ildikó és Dr. Molnár Annamária végezték.

Az embrionális fejlődés 15,5. napján (E15,5) a nőstényeket cervikális diszlokációval áldoztuk fel, az embriókat császármetszéssel nyertük ki.

\section{A transzgének jelenlétének igazolása}

\subsection{PCR}

A LacZ riporter gént hordozó egereket a LacZ szekvenciára tervezett primer párral azonosítottuk.

\section{LacZ-F 5'-CGCGTTTCATCTGTGGT-3'}

\section{LacZ-R 5'-CCGACATCGCAGGCTTC-3'}

A reakcióhoz farokból, vagy méhlepényből izolált DNS-t használtunk, melyhez a szöveteket éjszakán át emésztettük $0,5 \mathrm{mg} / \mathrm{ml}$ proteináz-K oldatban $55{ }^{\circ} \mathrm{C}$-on, majd a DNS-t fenol:kloroform:izo-amil-alkoholos kicsapással nyertük ki. Negatív kontrollként vad típusú egér DNS-ét használtuk. 


\subsection{Dot blot}

$20 \mu \mathrm{g}$ farokból izolált DNS-t 10 perces forralással denaturáltunk, majd 20xSSPEvel (3M NaCl, 200 mM NaH 2 PO4 pH7.4, 20 mM EDTA) összekeverve hidegen tartottuk. A Dot blot készülékre vízzel, majd 2xSSPE-vel megnedvesített Amersham nylon filtert és 20xSSPE-vel megnedvesített Watmann 3MM papírt helyeztünk. Minden mintából 2x120 $\mu l-t$ tettünk a lyukakba, majd vízlégszívóval vákuumot létesítve átszürtük azokat.

Ezután $3 \mathrm{M} \mathrm{NaCl}$ és $500 \mathrm{mM} \mathrm{NaOH}$ denaturáló keverékkel, majd 3M NaCl és $500 \mathrm{mM}$ Tris- $\mathrm{HCl}$ pH7.2 neutralizáló keverékkel itattuk át a filtert. Szárítás után UV fénnyel keresztkötöttük. (2 perc, $700 \mathrm{~kJ} / \mathrm{cm}^{2}$ ). A filtert két órán át, $65^{\circ} \mathrm{C}$-on, $5 x \mathrm{xSPE}$, 0,5xDenhards, 0,5\% SDS keverékében előhibridizáltuk. Ezután 2000000 cpm jelölt próbát adtunk hozzá és egy éjszakán át folytattuk a hibridizálást. Másnap a filtert $65^{\circ} \mathrm{C}$-on, 15 percig 1xSSC, 0,1\% SDS keverékében mostuk, majd ugyanígy 0,1xSSC, 0,1\% SDS keverékében.

A filtereket két napig exponáltuk, a radioaktív jeleket Typhoon 8600 (Molecular Dynamics) készülékkel jelenítettük meg. Kontrollként 2, 5, 10, 20 transzgén kópiának megfelelő plazmid DNS-t használtunk.

\section{A $\beta$-galaktozidáz aktivitás detektálása egész embrión és metszeten}

Az embriókat koruktól függően 10-30 percig tartottuk fixáló oldatban (100 mM nátrium-foszfát puffer ( $\mathrm{pH} 7,3), 0,2 \%$ glutáraldehid, $5 \mathrm{mM}$ EGTA, $2 \mathrm{mM} \mathrm{MgCl}$ ) szobahőmérsékleten, enyhén rázatva. Ezután a fixáló oldatot detergens oldatra cseréltük, majd 3x10-30 perc rázatás után $1 \mathrm{mg} / \mathrm{ml}$ X-gal (5-bromo-4-kloro-3-indol- $\beta$-Dgalaktopiranozid), $5 \mathrm{mM}$ kálium-ferricianid, 5mM kálium-ferrocianid, $20 \mathrm{mM}$ TRIS-HCl $(\mathrm{pH} 7,3), 2 \mathrm{mM} \mathrm{MgCl}, 0,01 \%$ nátrium-deoxikolát, 0,02\% NP-40 oldatban festettük éjszakán át, $37{ }^{\circ} \mathrm{C}$-on, sötétben. A festés utáni fixálást az előzőhöz hasonló, EGTA nélküli fixáló oldatban végeztük egy éjszakán át $4{ }^{\circ} \mathrm{C}$-on. Másnap az embriókat PBS-ben mostuk. A felvételeket DC300F kamerával felszerelt Leica MZFLIII sztereomikroszkóppal készítettuik.

A metszeten történő festéshez az embriókat az előzőekben leírtak szerint fixáltuk. Ezután a fixáló oldatot 20\% szacharózt tartalmazó 100 mM Na-foszfát pufferre $(\mathrm{pH}$ 7,3) cseréltük, és addig tartottuk benne az embriókat $4^{\circ} \mathrm{C}$-on, amíg azok lesüllyedtek az edény 
aljára. Ezt követően eltávolítottuk róluk a felesleges folyadékot és OCT Tissue Techbe ágyaztuk, szárazjégen lefagyasztottuk és metszésig $-70{ }^{\circ} \mathrm{C}$-on tároltuk őket. A blokkokból kriosztáttal $10 \mu \mathrm{m}$-es metszeteket készítettünk, melyeket 2 percig acetonban fixáltunk.

Detergens oldattal történő mosás után a metszetekre a fent leírt X-gal festéket tettünk és egy éjszakán át szobahőmérsékleten, sötétben, kevertetve festettük.

A metszeteket másnap detergenses mosóoldattal öblítettük le, majd $100 \mu 1,0,5 \%$-os, vízben oldott eozint cseppentettünk rájuk, 1 perc után vízzel lemostuk. Száradás után a metszeteket glicerin-zselatinnal lefedtük. A metszeteket Nikon Eclipse E600 mikroszkópra szerelt Spot RT Slider kamerával fotóztuk. Az ábrák elkészítéséhez Adobe Photoshop 8.0 és CorelDraw X4 programokat használtunk.

\section{Alkalmazott sejtkultúrák készítése}

\section{Csirke embrió fibroblaszt (CEF)}

Csirke primer fibroblaszt kultúrát 8-10 napos embriókból készítettünk [105]. Tripszines kezelés után a fibroblasztokat összegyüjtöttük és $10 \%$ szérummal kiegészített DMEM tápoldatban tartottuk. A másnap ismételt tripszinezés után $7 \times 10^{5}$ sejtet 24 lyukú lemezre tettünk ki.

\section{Csirke embrió porcsejt (CEC)}

A csirke primer chondrocyta kultúrához 14,5 napos csirke embriók porcos sternumát eltávolítottuk, majd 0,1 \%-os kollagenázzal emésztettük [105]. A sejteket 10\% szérummal kiegészített DMEM tápoldatban tartottuk. $7 \times 10^{5}$ sejtet 24 lyukú lemezre tettünk ki. Ez a kultúra főként késői proliferatív (I.b) stádiumú porcsejtekből áll.

\section{Nagy sejtsúrüségú mesenchyma (HDM)}

4,5 napos csirke embriók végtag kezdeményeiből tripszines emésztéssel chondroprogenitor sejteket preparáltunk, melyek nagy sürủségben tenyésztve porccá, míg kis sürűségben csonttá és kötőszövetté differenciálódnak. A chondrogenesis korai stádiumát képviselő HDM kultúrát úgy készítettük, hogy $5 \times 10^{6}$ sejtet lemezeltünk ki 35 mm átméröjü petri csészére, a sejteket 10\% szérummal kiegészített HAM (F-12):DMEM tápoldatok 6:4 arányú keverékében tenyésztettük. 


\section{Tranziens expresszió}

A CEC, CEF és HDM sejtkultúrákat transzfekció előtt 24 órával tripszineztük, majd $7 \times 10^{5}$, illetve $5 \times 10^{6}$ sejtsürüségben lemezeltük ki. A transzfekció a Ca-foszfát koprecipitációs módszerrel történt [105], melyhez a luciferáz riporter konstrukciókból 2, illetve $5 \mu \mathrm{g}$-ot használtunk. A transzfekció hatékonyságának ellenőrzésére pGL3 kontrol vektort (Promega) használtunk. A sejteket 48 (CEC, CEF), illetve 36 (HDM) órával a transzfekció után lecentrifugáltuk, $200 \mu$ lízis pufferben $(50$ mM Tris-HCl, 2 mM DTT, 0,5 mM EDTA, 0,5 mM EGTA, 1\% NP-40) feltártuk. A luciferáz aktivitást a felülúszóból mértük luciferin szubsztrát (Promega) hozzzáadásával Luminoscan Ascent (ThermoLabsystem 2.6) luminométeren.

Az eredmények 4-10 független mérés átlagai.

\section{Fehérje expresszió és tisztítás}

Az EMSA-hoz használt fehérjéket (GST-L-Sox5, GST-Ssox6, GST-SOX9) BL21 codon+RIL E. coli sejtekben termeltettük, amelyeket ampicilinnel kiegészített 2YT tápoldatban növesztettünk. A termelést $\mathrm{OD}_{600}=0,6$ értéknél 0,3 mM IPTG-vel indukáltuk, a sejteket $4 \mathrm{~h}$ múlva lecentrifugáltuk és lefagyasztottuk, majd $3 \mathrm{ml}$ lízis pufferben $(50 \mathrm{mM}$ Tris- $\mathrm{HCl} \mathrm{pH}$ 7,5, 150 mM NaCl, 1 mM DTT, 5 mM EDTA, 25 \% szukróz) szonikálással tártuk fel. Centrifugálás után a felülúszót glutation-szefaróz $4 \mathrm{~B}$ oszlopon $4{ }^{\circ} \mathrm{C}$-on 2 órán át forgattuk. Háromszor mostuk mosó I. (250 mM NaCl, 5 mM EDTA, 50 mM Tris-HCl pH 7,5), majd mosó II.(120 mM NaCl, 5 mM EDTA, 50 mM Tris-HCl pH 7,6) oldattal. Az oszlopról 10mM GSH hozzáadásával eluáltuk, protein tároló pufferrel (20 mM Tris-HCl pH7,9, $50 \mathrm{mM} \mathrm{KCl}, 4 \mathrm{mM} \mathrm{MgCl} 2,3 \mathrm{mM}$ DTT, 0,5 mM EDTA, 20\% glicerin) szemben 4 ${ }^{\circ} \mathrm{C}$-on éjszakán át dializáltuk. Az aliquotokat felhasználásig folyékony nitrogénben tároltuk.

\section{Sejtmagi kivonatok készítése EMSA és pull down kísérletekhez}

$10^{7}$ CEC, illetve CEF sejtet PBS-sel kétszer mostunk, majd $500 \mu \mathrm{l}$ A pufferben (10 HEPES pH7,9, $10 \mathrm{mM} \mathrm{KCl,} \mathrm{0,1} \mathrm{mM} \mathrm{EDTA)} 10$ percig szobahőn tartottuk. Centrifugálás után a csapadékot $1 \mathrm{ml} \mathrm{B}$ pufferben (20 mM HEPES pH 7,9, 400 mM NaCl, 1 mM EDTA, $10 \%$ glicerin) két órán át $4{ }^{\circ} \mathrm{C}$-on erősen rázattuk. Centrifugálás után a felülúszót kis 
mennyiségekre szétosztva folyékony nitrogénben tároltuk. Mindkét puffert a következő proteáz gátlókkal egészítettük ki: $1 \mathrm{mM}$ DTT, 0,5 mM PMSF, 0,001 $\mu \mathrm{g} / \mu \mathrm{l}$ aprotinin, leupeptin, pepsztatin A.

\section{EMSA}

30 fmol $\left[\gamma_{-}{ }^{32} \mathrm{P}\right]$ ATP végjelölt DNS próbát inkubáltunk $30^{\circ} \mathrm{C}$-on 30 percig tisztított, GST-fúziós SOX9, L-Sox5, Sox6 fehérjékkel 500 ng nem specifikus kompetítor [p(dGdC)] jelenlétében a következő pufferben: 100mM TrisHCl (pH7,9), $20 \mathrm{mM} \mathrm{MgCl}$, 0,5 mM EDTA, $11 \mathrm{mM}$ DTT, 0,25\% NP40, 8\% ficoll, $250 \mathrm{mg} / \mathrm{ml}$ BSA. Az elektroforézist elöfuttatott $(2 \mathrm{~h}, 200 \mathrm{~V}), 5 \%$-os poliakrilamid gélen $4{ }^{\circ} \mathrm{C}$-on $160 \mathrm{~V}$-tal végeztük $0,25 \%$ TBE pufferben. A gélt szárítás után két napig exponáltuk, a radioaktív jeleket Typhoon 8600 (Molecular Dynamics) készülékkel jelenítettük meg.

\section{Pull down}

A biotinilált oligonukleotidot (Pe1) a gyártó (Dynal magnetic beads, Invitrogen) utasítása szerint rögzítettük a mágneses gyöngyökhöz. A nem specifikus kötések kivédésére a sejtmagi kivonatokat üres gyöngyökkel inkubáltuk 20 percig szobahőn a következő pufferben: $20 \mathrm{mM}$ Tris pH7,4, $50 \mathrm{mM} \mathrm{KCl,} \mathrm{3,5} \mathrm{mM} \mathrm{DTT,} \mathrm{0,2} \mathrm{mM} \mathrm{EDTA,} 4$ $\mathrm{mM} \mathrm{MgCl}_{2}$. Ezután a kivonatot $100 \mu \mathrm{l}$ gyöngyhöz rögzített oligonukleotidhoz adtuk, ugyanebben a pufferben 40 percig, szobahőn, lassan mozgattuk. Elúciókor a gyöngyökhöz 2xLaemmli mintapuffert adtunk, 5 perc forralás után 10\%-os poliakrilamid gélen futtattuk. A gélből Coommassie G250 festés után kivágtuk a specifikus csíkokat, melyeket az SZBK Proteomikai laboratóriumában azonosítottak. Ehhez a diszulfid hidak DTT-vel való redukálása után tripszines emésztést alkalmaztak. A mintákat LC/MSMS készülékkel (Agilent) analizálták, a peptideket a MASCOT, illetve ProteinProspector adatbázisok segítségével azonosították. 


\section{ELŐZETES EREDMÉNYEK}

\section{A matrilin-1 gén szabályozásáról a csoportban korábban született eredmények}

Csoportunk tagjai korábban elsőként klónozták a csirke matrilin-1 gént [103], illetve térképezték annak fő szabályozó régióit [104,105]. Tranziens expressziós kísérletekből kiderült, hogy a -1137/+64 bp promoter fragment képes a szövet-és fejlődési állapotspecifikus kifejeződést irányítani két pozitív (PRI, PRII) és két negatív (SI, SII) szabályozó elem együttmüködése eredményeképpen. Az SI elemen Nfi kötőhelyeket azonosítottak [105].

Később transzgenikus egér kísérletekben is bebizonyosodott, hogy a TR70 transzgén, melyet a hosszú promoter (-2011/+67) önmagában irányít, elegendő információt hordoz ahhoz, hogy a transzgén expressziót a fejlődő végtag elemekbe, tengelyvázba és a chondrocraniumba irányítsa (5. ábra). A LacZ expresszió megfigyelhető volt még a csigolyatestekben, a notochordban és a szemben is [107].

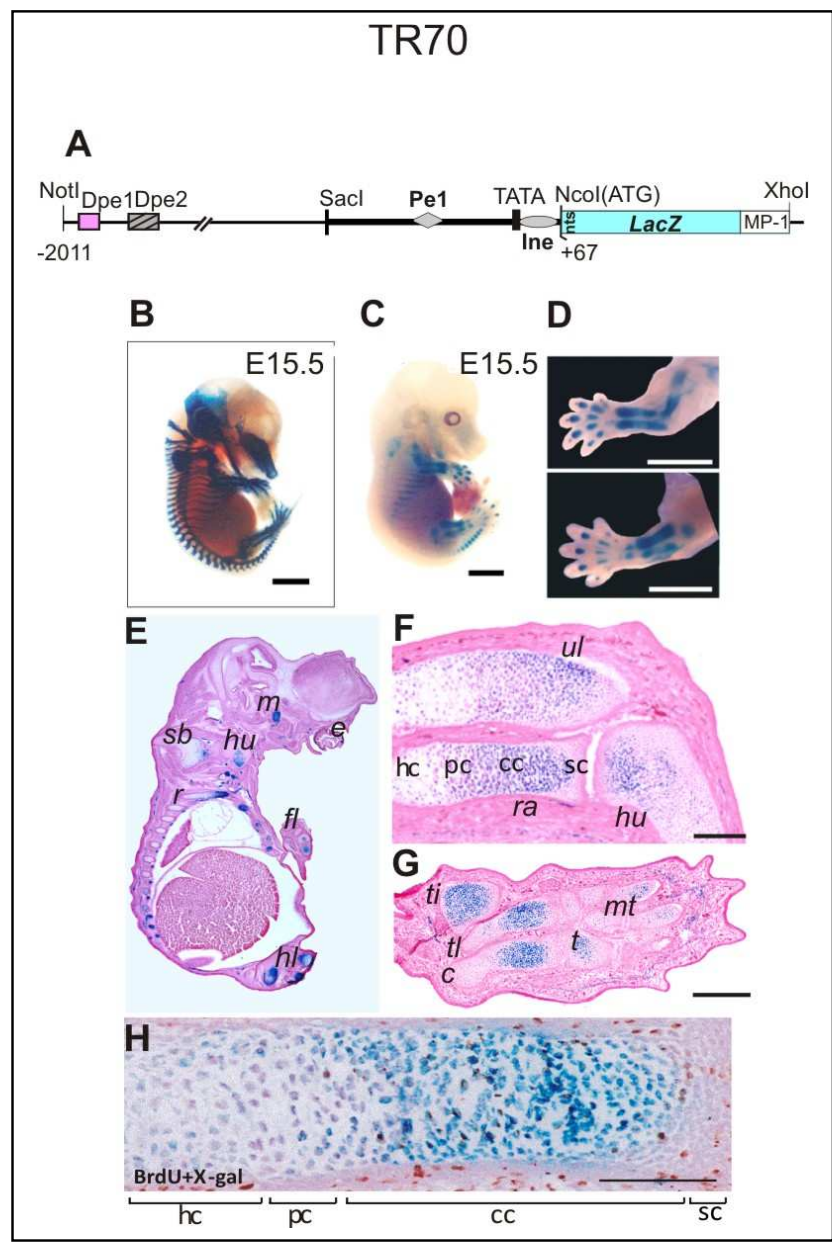

5. ábra A TR70 transzgén elegendő információt tartalmaz ahhoz, hogy magas szintü expressziót irányítson az összes fejlődő vázelembe. A transzgén (A) kifejeződési mintázata az alapító embrió tengely -és végtagvázában proximo-disztális irányítottságot mutat (C,D), összehasonlítva a minden porcos vázelemet megjelenítő alcián kék festéssel (B). Az expresszió a növekedési korong oszlopos proliferatív (cc) és prehipertróf (pc) zónáira korlátozódik $(\mathrm{F}, \mathrm{H})$ [107]. A BrdU festés a proliferatív sejteket jelöli. C, calcaneus; cc, oszlopos proliferatív porcsejtek; e, szem; fl, mellső végtag; hc, hipertróf porcsejtek; hl, hátsó végtag; hu, humerus; m, Meckel-féle porc; mt, lábközépcsont; pc, prehipertróf porcsejtek; r, borda; sb, lapocka; sc, forrás porcsejtek; ti, tibia; tl, talus. Méretvonal 2mm (B-D); $200 \mu \mathrm{m}$ (F,G); $100 \mu \mathrm{m}$ (H). 
A VAM2 transzgén, ami a rövid promotert és az introni szabályozó régiót tartalmazta $(-338 /+1819)$ szintén képes volt a transzgén kifejeződését a végtagváz, a tengelyváz és a chondrocranium porcos elemeibe irányítani, de a LacZ expresszió alacsonyabb szintủ volt és a vizsgált embriókban különböző mintázatú ektopikus expresszióval társult más szövetekben is, például középagy, trigeminális ideg, szaglóhám, bőr, tüdő. Mivel ez a mintázat nem egyezett meg az összes vizsgált alapító embrióban és a homozigóta vonalból származó egyedekben, valószínű, hogy a transzgénben jelenlévő porcspecifikus szabályozó elemek az integrálódási hely közelében lévő szabályozó elemekkel kölcsönhatva irányították az expressziót a porcszöveten kívül más struktúrákba is. Ezt támasztja alá az is, hogy a VAM1 transzgén esetében, mely a hosszú promotert és az introni szabályozó régiót tartalmazza (-2011/+1819), ez az ektopikus kifejeződés nem volt megfigyelhető. Ez arra utal, hogy az ektopikus kifejeződést irányító elemek valószínűleg a -2011/-338 régióban találhatók. Mindhárom transzgén kifejeződésére jellemző volt, hogy a növekedési korongok proliferatív és prehipertróf zónáira korlátozódott (5. ábra), illletve, hogy a disztális struktúrákban a kifejeződés mértéke magasabb volt, mint a proximális elemekben. E transzgenikus egér adatok arra utaltak, hogy a matrilin-1 gén porcspecifikus szabályozó elemei elszórtan helyezkednek el a szabályozó régióban, illetve, hogy a génmüködést a távoli promoteren és az introni régióban modulárisan elhelyezkedő enhancer és silencer elemek együttműködve irányítják [107]. Mivel a magas aktivitású konstrukciók mindegyike tartalmazta a rövid promotert (334/+67), valószínủnek látszott, hogy ez a szakasz tartalmazza azokat a fő szabályozó elemeket, melyek a gén szövet- és fejlődési állapotspecifikus expresszióját irányítják, illetve a távoli elemek hatását közvetítik. Ezek azonosítására munkatársaim in silico analízist végeztek, melynek során a rövid promoteren belül több, amniotákban különbözö mértékben konzervált szekvenciát találtak [80]. Ezek közül a legnagyobb mértékü konzerváltságot egy proximális promoter elem (Pe1) mutatta, amely egy pár, egymással ellentétes irányban elhelyezkedő motívumot tartalmaz, mely jelentős mértékủ homológiát mutat a Sox9 transzkripciós faktor preferált kötőhelyével. A Pe1 elemről in vitro DNSfehérje kötési kísérletekben kiderült, hogy képes SOX9, L-Sox5 és Sox6 transzkripciós faktorokkal, illetve egy eddig azonosítatlan faktorral is komplexet képezni. A Sox motívumok pontmutációi gátolták az elemen a komplexképződést, illetve jelentős mértékben csökkentették a matrilin-1 gén szövetspecifikus müködését tranziens expressziós kísérletekben. További in vivo footprint adatok megerősítették, hogy a Pe1 elem Sox motívumaihoz porcspecifikus transzkripciós faktorok kötődnek [80]. 
A rövid promoter iniciációs eleme (Ine) emlösökben szintén konzervált, de amniotákban már kevésbé. Ezen az elemen két pár invertált Sox motívum található, melyek in vitro kísérletekben szintén komplexet képeztek tisztított Sox9 fehérjével. Csirke chondrocyta sejtmagi kivonattal inkubálva ezen az elemen három nukleoprotein komplex alakult ki, melyek közül kettőt Sox9, L-Sox5 és Sox6 ellenanyagok felismertek, jelezve azt, hogy az Ine elemnek is meghatározó szerepe van a matrilin-1 gén szövetspecifikus szabályozásában.

A csirke matrilin-1 gén rövid promoterében a TATA boxtól 5' irányban egy Nfi kötőhelyet is azonosítottak, melynek szintén lehet szerepe a génexpresszió szabályozásában.

A rövid promoter konzervált elemein kívül két távoli promoter elem (Dpe1 és Dpe2) mutatott kisebb fokú szekvencia homológiát a csirke és emlős gének között. A Dpe1 elemen az L-Sox5/Sox6 transzkripciós faktorok preferált kötőhelyével közel azonos szekvencia található [80].

A matrilin-1 gén első intronjában korábban azonosított 102 bp-os enhancer elem $\left(\mathrm{E}_{102}\right)$, és az azon belül található LIE elem [104] valószínüleg szintén szerepet játszanak a gén kifejeződésének szabályozásában. In vitro kísérletekben kiderült, hogy ezekhez az elemekhez Sox9 és Nfi faktorok kötődnek [108]. 


\section{EREDMÉNYEK}

\section{A rövid promoter szerepe a matrilin-1 gén expressziójának szabályozásában}

\subsection{A rövid promoter aktivitása alacsony transzgenikus egerekben}

Az előbbiekben említett TR70, VAM1 és VAM2 transzgének szövetspecifikus expressziót mutattak, amely a növekedési korong meghatározott zónáira korlátozódott. Mindhárom konstrukció közös eleme a rövid promoter volt, ezért először ennek szerepét kívántuk tisztázni a gén térbeli és időbeli kifejeződésének szabályozásában in vivo. Ebből a célból olyan plazmidot hoztunk létre, ami a LacZ riporter gént a matrilin-1 rövid promoter (-334/+67) irányítása alatt tartalmazta (NAD1) (6. ábra A). A konstrukcióval pronucleus mikroinjektálással hoztunk létre transzgenikus egereket. Összesen 12 alapító embriót izoláltunk, melyek a NAD1 transzgént detektálható mértékben expresszálták (6. ábra B).

A 15,5 napos embriókon végzett hisztológiai vizsgálat arra utalt, hogy a transzgén minden fejlődő vázelemben kifejeződik (6. ábra C-T). Az expresszió mértéke sokkal alacsonyabb volt, mint a VAM2 transzgén esetében, amely a rövid promoter mellett introni elemet is tartalmazott. Az alig detektálható $L a c Z$ expresszióban bizonyos mértékủ zonális különbségek voltak megfigyelhetők, így például a fejlődő hosszú csontokban (pl. femur, humerus) (6. ábra E,F,G,L), a csigolyatestekben (6. ábra I,J,O-Q) a transzgén aktivitása legnagyobb volt a növekedési korong proliferatív és prehipertróf zónáiban, míg az epifízeális, a forrás és a hipertróf porcsejtek zónáiban nem detektáltunk expressziót. További eltérés a már említett transzgénekhez képest, hogy a NAD1 transzgén esetében a kifejeződés mértéke nem tért el a proximális és disztális vázelemekben (pl. nyaki és farki csigolyák) (6. ábra I,J,O-Q). Néhány vizsgált embrió esetében tapasztaltunk különböző mértékű ektopikus kifejeződést például a szaglóhámban (6. ábra T), a belső fül félkörös ívjárataiban (6. ábra $S$ ), a vázizmokban (6. ábra $M, N$ ), vagy a tüdőben. Mivel ezek mintázata nem minden embrió esetében egyezett meg, valószínü, hogy az ektopikus kifejeződést a transzgén integrációs helye befolyásolta.

Ezekből az adatokból arra következtettünk, hogy a rövid promoter képes ugyan bizonyos szintű szövet- és fejlődési állapotspecifikus génkifejeződést irányítani, de az aktivitása önmagában alig detektálható, és nem mutat proximo-disztális különbségeket 
sem. Tehát a rövid promoter önmagában nem felelős a gén szűkített, porcspecifikus kifejeződését irányítani, ehhez a távoli DNS elemek szükségesek.

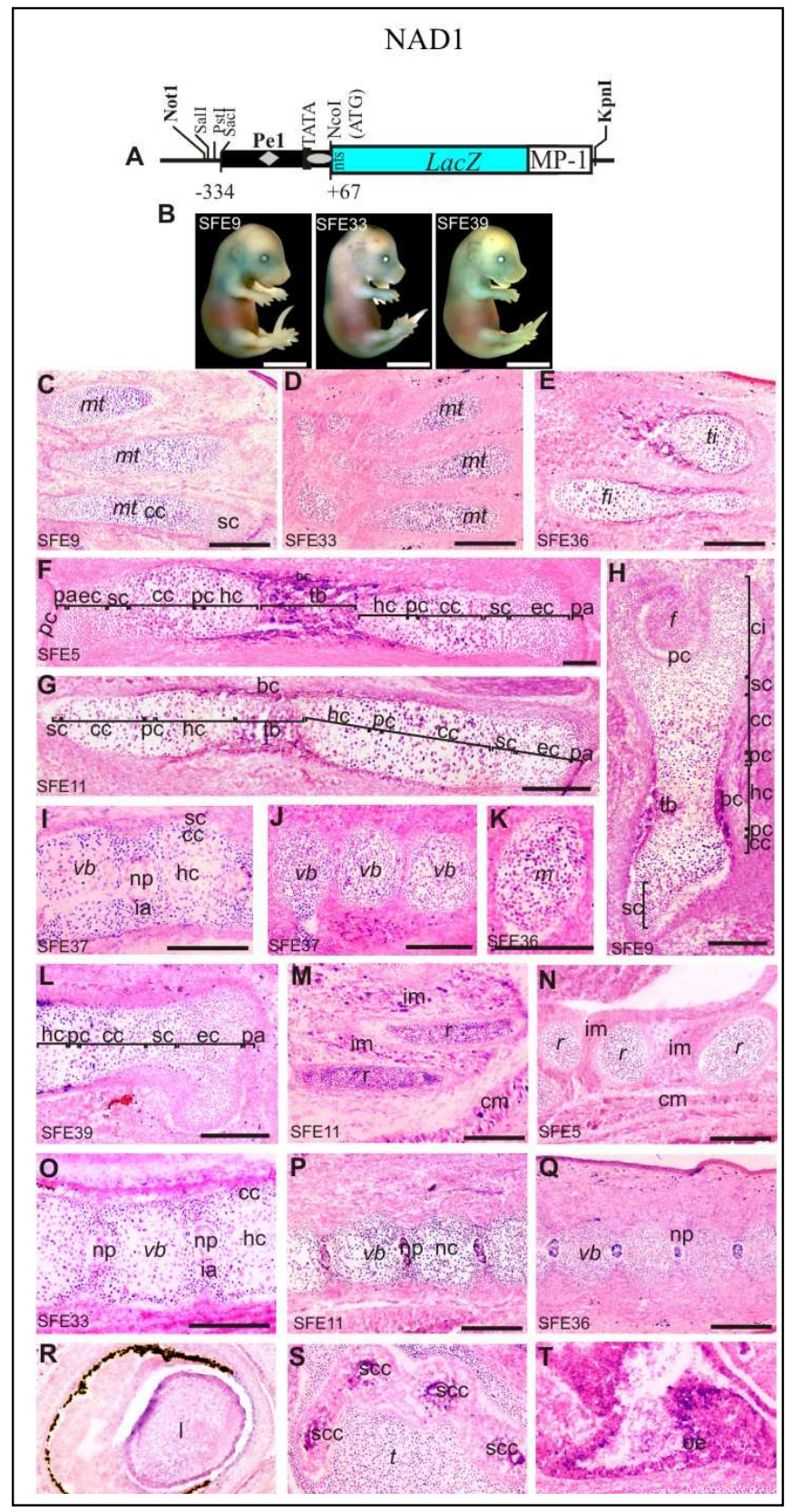

6. ábra A rövid promoter önmagában alacsony expressziós szintet biztosít. A NAD1 transzgén térképe (A) és a 15,5 napos (E15,5) embriók vázelemeiben detektálható kismértékủ LacZ expresszió (B). A transzgén minden porcos vázelemben alacsony szinten fejeződik ki (C-T). Az expresszió a fejlődő hosszú csontok növekedési korongjának proliferatív és prehipertróf zónáira korlátozódik, míg az epifízeális (epi) és forrás chondroblastokban, valamint a hipertróf zónában nem megfigyelhető (F,G,H,L). Az expresszió mértéke összehasonlítható a craniális (cran) (I), lumbális (lumb) (O) és caudális (caud) (J,P,Q) csigolyatestekben (vb). Gyenge festödés figyelhető meg a Meckel porcban (m) (K), a falcsont kezdeményében (t) (S) és az orrporcban $(\mathrm{nb})(\mathrm{T})$, valamint a bordákban $(\mathrm{M}, \mathrm{N})$ és a szemben (R). Ektopikus expresszió detektálható nem porcos szövetekben is: a szaglóhámban (oe) (T), a belső fül félkörös ívjáratainak epitheliális sejtjeiben (scc) $(\mathrm{S})$, a bordaközti (im) és bör alatti izmokban $(\mathrm{cm})(\mathrm{M}, \mathrm{N})$. További rövidítések: ib, medencecsont; mc, kézközépcsont; f, femur; l, szemlencse, np, nucleus pulposus; pa, periartikuláris porcsejtek; pl, retina pigment rétege. Egyéb rövidítések: ld. 5. ábra. Méretvonal 2 mm (B) $200 \mu \mathrm{m}$ (A-J, H-T), 100 m (K). 


\subsection{Távoli homológ promoter régiók növelik a rövid promoter aktivitását}

Mivel a rövid promoter önmagában alacsony aktivitást mutatott, feltételeztük, hogy távolabbi elemek müködésére is szükség van a megfelelő mértékủ expresszióhoz.

A továbbiakban arra kerestünk választ, hogy a disztális promoter régiók, melyek több, különböző mértékben konzervált szabályozó elemet, illetve transzkripciós faktor kötőhelyet tartalmaznak, milyen módon járulnak hozzá az endogén génre jellemző kifejeződési mintázathoz. Ehhez először tranziens expressziós kísérletekben vizsgáltunk meg olyan konstrukciókat, melyek a matrilin-1 gén promoterének különböző hosszúságú szakaszait tartalmazzák (7. ábra).

A konstrukciók aktivitását három különböző sejtkultúrán vizsgáltuk. A nagy sürüségű mesenchyma (HDM) kultúra a porcfejlődés korai stádiumát reprezentálja, kizárólag korai proliferatív (Ia. stádiumú) porcsejtekből áll $[13,14]$. Ezzel szemben a csirke chondrocyta (CEC) kultúra késői proliferatív (Ib. stádiumú) porcsejtekben gazdag. A csirke embrionális fibroblaszt (CEF) kultúra pedig a matrilin-1 gént nem expresszáló sejttípus.

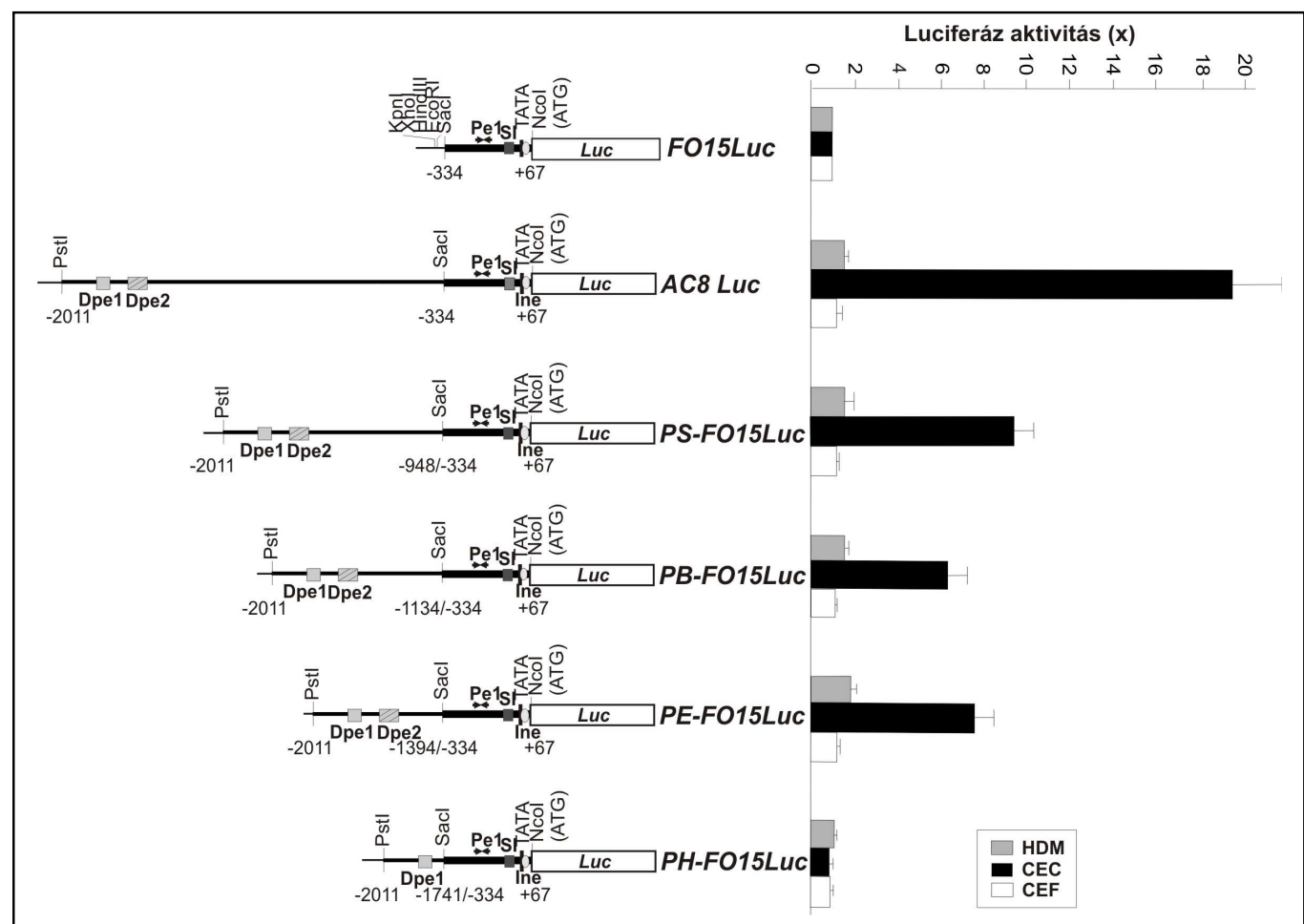

7. ábra A teljes hosszúságú és a rövidített távoli promoter régiók által meghajtott luciferáz riporter konstrukciók szerkezete és szövetspecifikus aktivitása tranziens expressziós kísérletben. A diagram az egyes konstrukciók FO15-Luc-hoz viszonyított relatív aktivitását mutatja nagy sűrűségü mesenchyma (HDM) kultúrában, mely a porcfejlődés korai stádiumát reprezentálja, a matrilin-1-et expresszáló csirke chondrocyta (CEC) és az azt nem expresszáló csirke fibroblaszt (CEF) sejtkultúrákban. 
Azt tapasztaltuk, hogy a promoter hosszának növelésével a késői proliferatív porcsejtekben mért aktivitás is nő, míg a másik két sejttípusban az expresszió mértéke nem változott lényegesen (7. ábra). Tehát a szövet- és differenciálódási állapot specifikus, magas szintủ génexpresszió irányításában valamely távoli promoter elem is szerepet játszik.

Hogy ezen elemek in vivo szerepére is fényt derítsünk, elkészítettük a szabályozó elemek LacZ riporter génnel fuzionált változatait, melyek közül azzal a kettővel hoztunk létre transzgenikus egereket, melyek a legmagasabb aktivitást mutatták a tranziens expressziós kísérletekben. A PS-NAD1 transzgén a matrilin-1 promoter -2011/-948 bp szakaszát tartalmazta a rövid promoter elé építve (8. ábra A), míg a PB-NAD1 transzgén a -2011/-1134 bp szakaszt (9. ábra A).

A konstrukciókat expresszáló 15,5 napos embriók hisztológiai vizsgálata azt mutatta, hogy a -2011/-1134 régió kisebb mértékben növelte a rövid promoter aktivitását, mint a -2011/-948 régió, viszont az expresszió proximo-disztális irányú növekedése, illetve a zonális mintázat mindkét esetben megmaradt. A PS-NAD1 és PB-NAD1 transzgéneket hordozó egerek vizsgálatakor azt tapasztaltuk, hogy a konstrukciók minden fejlődő vázelemben aktívak (8. ábra B,C, 9. ábra B,C). A $L a c Z$ expresszió mértéke mindkét esetben meghaladta ugyan a NAD1 transzgénét, viszont alacsonyabb volt, mint a TR70 esetében, mely a teljes hosszúságú promotert tartalmazza. Az expresszió a fejlődő hosszú csontok növekedési korongjának proliferatív és prehipertróf zónáira korlátozódott (8. ábra D,G,H,N, 9. ábra E,I), viszont a PS-NAD1 esetében érdekes módon az adott zónán belül nem minden sejt festődött azonos mértékben (8. ábra D,G,H,N).

Adataink megerősítették azt, hogy a magasabb szintü szövet- és fejlődési állapotspecifikus expresszióhoz szükség van a távoli promoter elemek jelenlétére. Ez alapján arra következtetünk, hogy a matrilin-1 promoter -2011/-334 szakasza a gén aktivitását a DNS szakasz hosszával párhuzamosan növeli, de a térben és időben szükített porcspecifitást nem befolyásolja. 


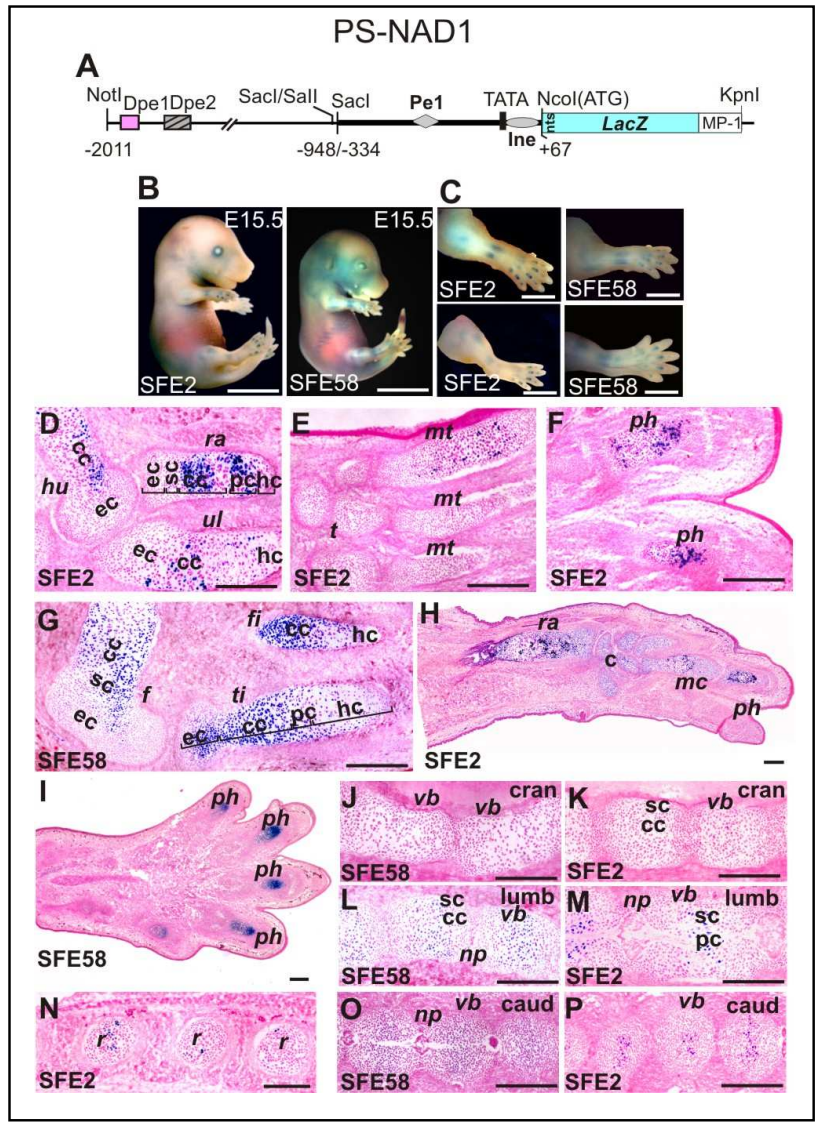

8. ábra A távoli promoter elemek növelik a Matn-1 rövid promoter aktivitását in vivo. A PS-NAD1 transzgén térképe (A) és kifejeződési mintázata a transzgenikus embriókban (B) és azok fejlődő végtagvázában (C). Az eozinnal festett fagyasztott metszeteken látható, hogy a mellső $(\mathrm{D}, \mathrm{H}, \mathrm{N})$ és hátsó végtag $(\mathrm{G})$ fejlődő hosszú csontjaiban az expresszió az oszlopos proliferatív és prehipertróf porcsejtek zónáira korlátozódik (D,G,H,N). Az adott zónán belül a $L a c Z$ expresszió csak a sejtek bizonyos csoportjaiban magasabb. A festődés intenzitása nagyobb a caudális $(\mathrm{O}, \mathrm{P})$ és lumbális $(\mathrm{L}, \mathrm{M})$ csigolyákban, míg a craniális csigolyákban $(\mathrm{J}, \mathrm{K})$ nem detektálható. Méretvonal 2 mm (B,C), $200 \mu \mathrm{m}$ (D-P). Egyéb jelölések: ph, ujjak; további jelöléseket ld. 5. ábra.

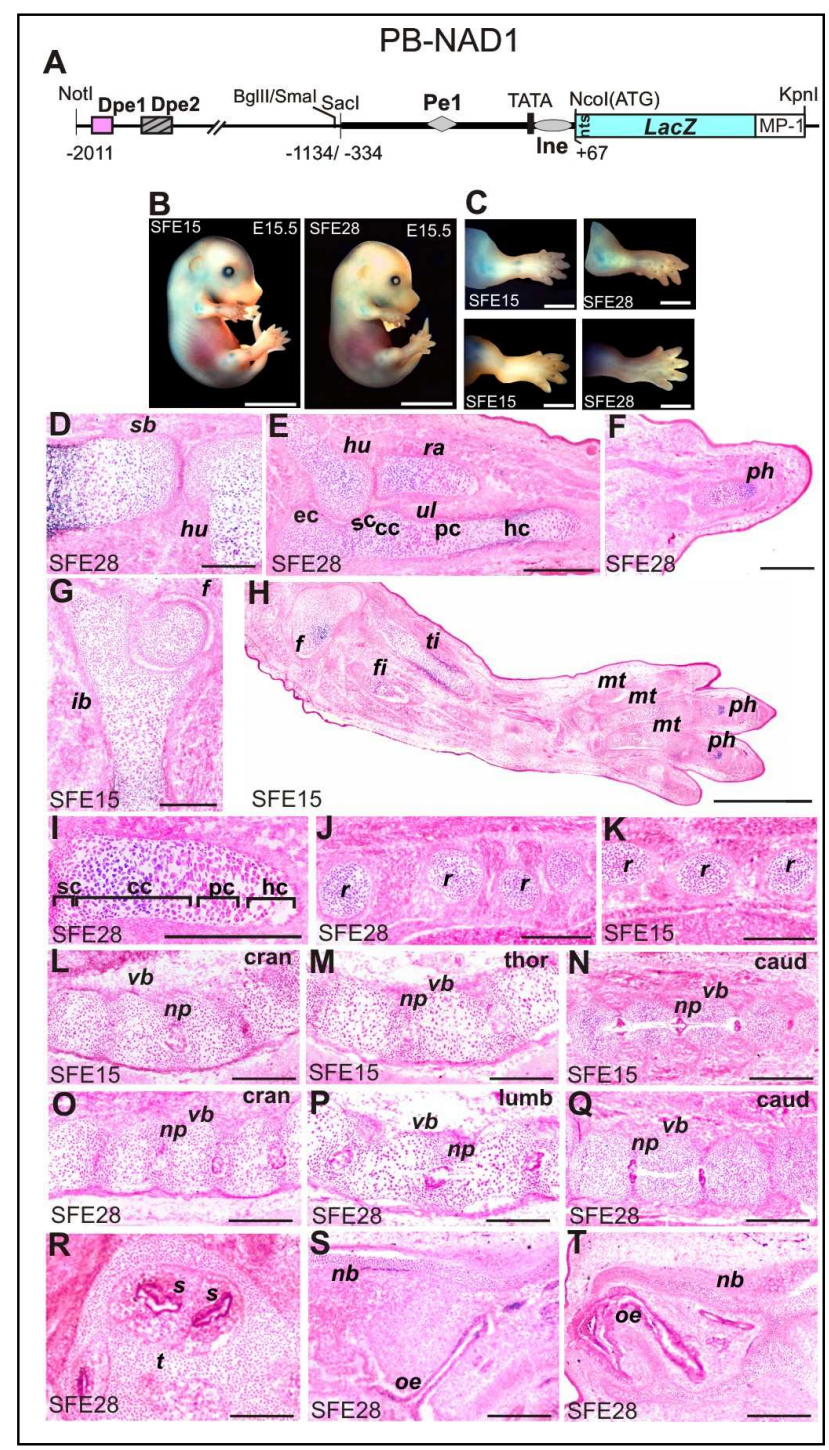

9. ábra A PB-NAD1 transzgén expressziós mintázata. A transzgén térképe (A). Az X-gal festett alapító embriók tengely- (B) és végtagvázában (C) figyelhetô meg a hosszabb távoli promoter szakaszt tartalmazó transzgénénél alacsonyabb szintủ expresszió. A fagyasztott metszetek hisztológiai analíziséből (D-T) kiderül, hogy a transzgén kifejeződés erősebb a farki $(\mathrm{N}, \mathrm{Q})$, mint a nyaki $(\mathrm{L}, \mathrm{O})$ és ágyéki $(\mathrm{M}, \mathrm{P})$ csigolyákban. A LacZ expresszió a disztális struktúrák irányába erősödést mutat, így az ujjakban intenzívebb festődést tapasztalunk $(\mathrm{F}, \mathrm{H})$. A transzgén expresszió a fejlődő hosszú csontok növekedési korongjának oszlopos proliferatív és prehipertróf zónáira korlátozódik (E,H,I). Látható még festődés a bordákban $(\mathrm{J}, \mathrm{K})$, valamint a fejlödő chondrocranium elemeiben: a falcsontban $(\mathrm{R})$ és az orrporcban (S,T). Méretvonal $2 \mathrm{~mm}$ (B,C), $200 \mu \mathrm{m}$ (D-T). További jelölések: sb, lapocka; ld. 5,7. ábrák. 


\subsection{A matrilin-1 rövid promoter felülírja az erős heterológ porcspecifikus enhancer elem hatását}

Következő lépésként megvizsgáltuk, hogy a Col2al génben korábban azonosított, 48 bp-os, porcspecifikus minimál enhancer elem [109] milyen hatással van a rövid promoter aktivitására. Irodalmi adatokból ismert, hogy ez az enhancer elem több kópiában, a teljes Col2a1 enhancerhez hasonlóan, fejlődési állapottól függetlenül, minden porcsejtben magas aktivitással müködik és heterológ promotert is hasonlóan aktivál. Először tranziens expressziós kísérletekhez készítettünk olyan klónokat, melyekben a luciferáz riporter gént a Matnl rövid promoter együtt irányítja a Col2al enhancer elem több kópiájával, különböző orientációkban (10. ábra).

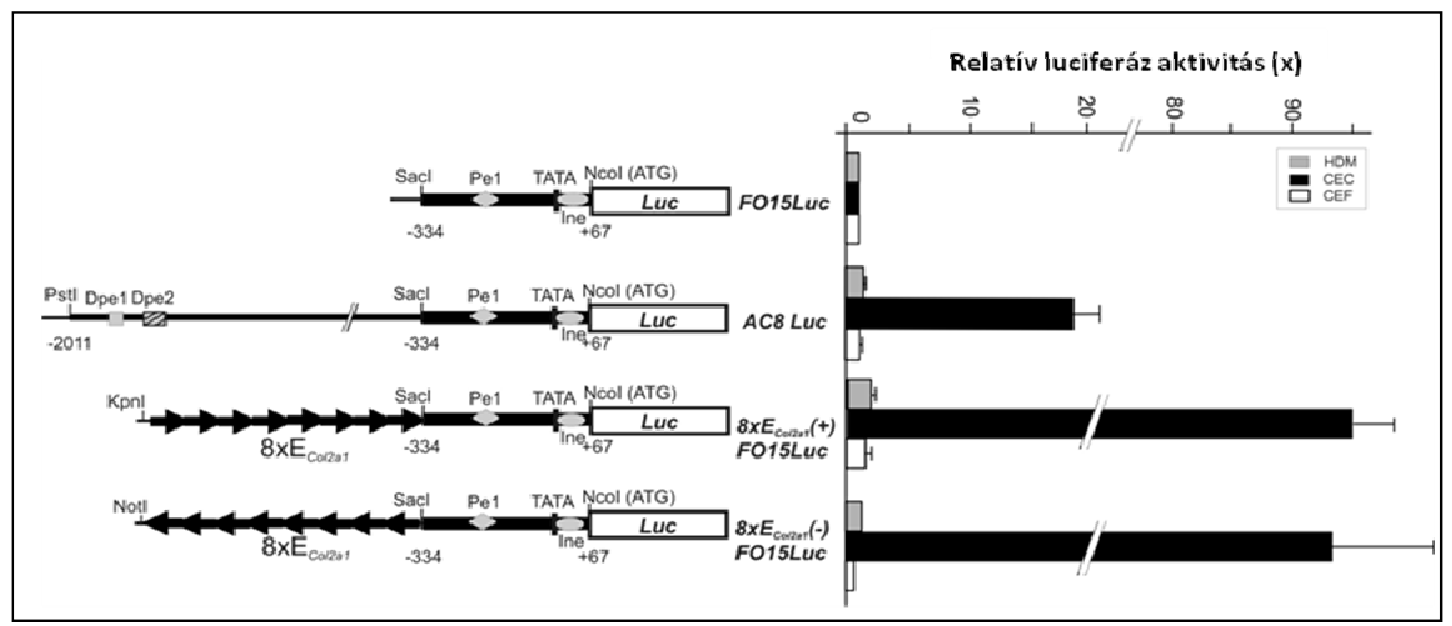

10. ábraA Col2a1 enhancer elem nyolc kópiája orientációtól függetlenül nagymértékben növeli a rövid promoter aktivitását tranziens expressziós kísérletekben. A diagram az egyes konstrukciók FO15-Luchoz viszonyított relatív aktivitását mutatja HDM, CEC és CEF kultúrákban.

A tranziens expressziós kísérletekben azt tapasztaltuk, hogy a Col2al enhancer elem nyolc kópiája orientációtól függetlenül drámaian (>90x) növeli a rövid promoter aktivitását. Mivel ez a növekedés csak a késői proliferatív chondroblastokban gazdag CEC kultúrában volt megfigyelhető, elmondható, hogy az enhancer elem a várt magas aktivitással, de szövet- és fejlődési állapot specifikusan működik (10. ábra).

A Col2al enhancer elemmel végzett transzgenikus egér kísérletekhez kontrollként a p3000i3020Col2a1 transzgént használtuk, melyben a $\beta$-galaktozidázneomicyn fúziós fehérje ( $\beta$-geo) expresszióját a Col2al gén hosszú promotere és introni enhancere irányítja (11. ábra A). Ezt a plazmidot B. de Crombrugghe bocsátotta rendelkezésünkre. 
Az irodalmi adatok alapján a transzgéntől azt vártuk, hogy minden porcos elemben egyformán magas aktivitással fog kifejeződni, függetlenül azok fejlődési stádiumától. Ennek megfelelően a 15,5 napos F0 embriók X-gal festésekor nagyon erős és hasonló intenzitású expressziót figyeltünk meg a végtagváz, a tengelyváz és a koponya valamennyi fejlődő porcos vázelemében (11. ábra B,C). A fagyasztott metszetek hisztológiai vizsgálata igazolta a magas szintü $L a c Z$ expressziót minden fejlődő porcos vázelem valamennyi porcsejtjében (11. ábra $\mathrm{C}-\mathrm{O}$ ). A transzgén kifejeződött minden fejlődési stádiumú porcsejtben és a növekedési korongok minden zónájában, beleértve a perichondriumot, a prechondrocytákat, az ízületi és epifízis porcot, a forrás, proliferatív és prehipertróf zónát. Csak a hipertróf zóna sejtjeiben mutatta a várt, jelentős csökkenést (11. ábra D-G,J,K,N). Az ízületi porcban és más porcsejtekben megfigyelt magas szintü génexpresszió alkalmassá teszi a p3000i3020Col2a1 plazmidot arra, hogy általános porcspecifikus vektorként használjuk.

Azt terveztük, hogy a Col2al enhancert a Matn1 rövid promoter elé építve magas riportergén expressziót érhetünk el transzgenikus egerekben, így azok alkalmazott kutatási feladatokra (gyógyszertesztelés) is felhasználhatók. Ezért a Col2al enhancer elemet 4, 8 és 16 példányban beépítettük a NAD1 vektorba, így a Matn1 rövid promoterrel együtt irányították a LacZ gén expresszióját.

$\mathrm{Az} \mathbf{E}_{\text {Col2a1 }}$ elemet négy példányban a $L a c Z$ riportergén elé építve (12. ábra $\mathrm{A}$ ) minden fejlődő vázelemben jelentős mértékben megnövelte a transzgén expressziót (12. ábra B), de érdekes módon kifejeződési mintázata jobban hasonlított a TR70, mint a p3000i3020Col2a1 transzgénére (11. ábra). Bizonyos mértékủ proximo-disztális és zonális különbségeket is mutatott (12. ábra C-J).

Hogy az enhancernek a rövid promoter müködésére gyakorolt hatását tovább vizsgáljuk, transzgenikus egerek előállításához olyan konstrukciót hoztunk létre, melyben a LacZ riporter gén kifejeződését a Col2a1 enhancer nyolc kópiája és a matrilin-1 rövid promoter irányítja egymással megegyező orientációban (13. ábra A). Az injektálás után két olyan alapító embriót izoláltunk, melyek minden fejlődő porcos vázelemben magas szinten expresszálták a transzgént (13. ábra B). Részletes hisztokémiai vizsgálat alapján kiderítettük, hogy meglepő módon az expresszió egyáltalán nem a Col2al génre jellemző, általános porcspecifitást mutatja, hanem a matrilin-1 génre jellemző, de még annál is kifejezettebb proximo-disztális irányítottságot. Ez jól megfigyelhető, ha összehasonlítjuk a festődés intenzitását a craniális, lumbális és caudális csigolyatestekben (13. ábra M-R). 
Ugyanez a tendencia látható, ha a végtagok hosszú csontjaiban és az ujjakban vetjük össze a festődés mértékét (13. ábra C-J).

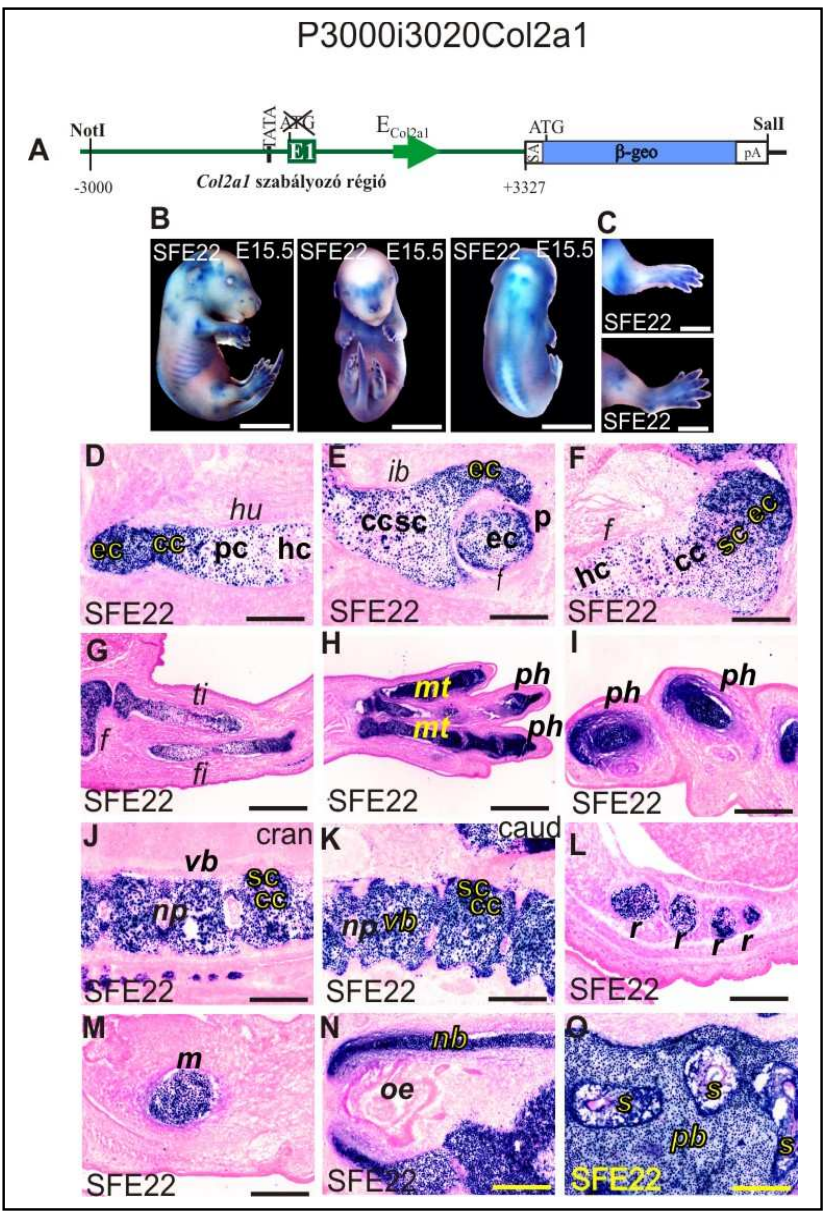

11. ábra A p3000i3020Col2a1 általános porcspecifkus vektor. A vektor térképe (A). Az alapító embriók chondrocraniumában és összes fejlődő vázelemében nagy intenzitású festődés figyelhető meg (B,C). A fagyasztott metszetek hisztológiai vizsgálatából is kiderül, hogy a végtagok fejlődő hosszú csontjainak minden porcsejtje festődik (D-G), hasonlóan a végtagok függesztő öveinek elemeihez (E,F) és az ujjakhoz (H,I). A gerinc nyaki (J) és farki (K) régiójában és a bordákban (L) is egyforma intenzitású a festődés. Ez látható még a Meckel-féle porcban (M), az orrporcban (N) és a falcsontban $(\mathrm{O})$ is. Az expresszió szintje minden porcsejtben magas, függetlenül azok fejlödési stádiumától (D-F, J,K), sőt a perichondrium és a kondenzálódó mesenchyma sejtek is festődnek (D-F,J,K). Méretvonal $2 \mathrm{~mm}$ (B,C), $200 \mu \mathrm{m}$ (D-O). További jelölések: ld. 5,7. ábrák.

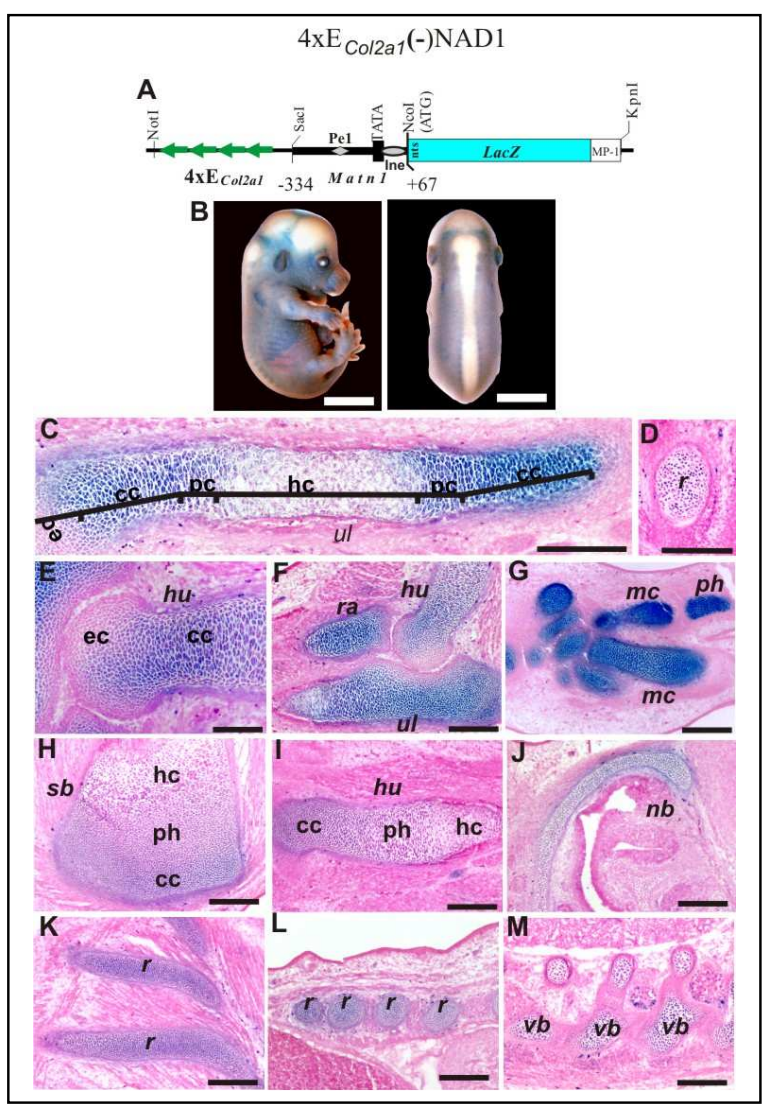

12. ábra $A z E_{C o l 2 a 1}$ elem négy példánya jelentősen megnöveli a rövid promoter aktivitását. A transzgén térképe (A) és expressziós mintázata az alapító embrió vázelemeiben (B). Az X-gal festődés intenzitása proximo-disztális irányban nő a lapockától (H) és humerustól (E,F) a radius és ulna felé (C,F,I). A legmagasabb szintű expresszió a kézközépcsontokban és az ujjakban figyelhető meg (G). A legintenzívebb festődés a hosszú csontok növekedési korongjának oszlopos proliferatív és prehipertróf zónáiban figyelhető meg (C,H,I). Gyengébb expresszió figyelhető meg a bordákban $(\mathrm{D}, \mathrm{K}, \mathrm{L})$, az orrporcban $(\mathrm{J})$ és a csigolyatestekben $(\mathrm{M})$. Méretvonal $2 \mathrm{~mm}$ (B), $200 \mu \mathrm{m}$ C-M). További jelölések: ld. 5,7. ábrák. 


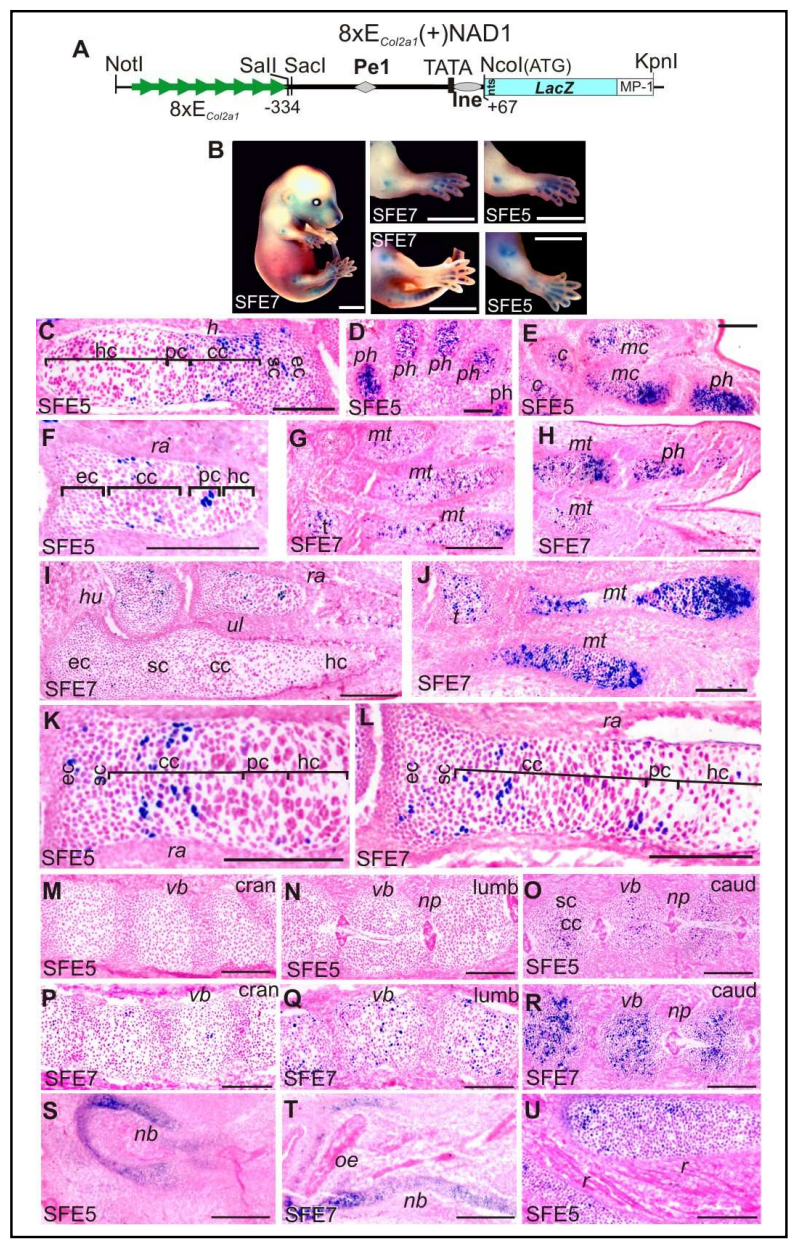

13. ábra $\mathrm{Az} \mathbf{E}_{\text {Col2a1 }}$ elem nyolc kópiája nagymértékben növeli a rövid promoter aktivitását. A transzgén térképe (A) és intenzív X-gal festődés a tengelyváz és végtagváz struktúráiban (B). A metszetek hisztológiai vizsgálata (C-U) alátámasztja, hogy a transzgén expresszió a fejlődő hosszú csontok növekedési korongjában az oszlopos proliferatív és prehipertróf zónákban a legmagasabb szintü (C,F,I,K,L). Festődés nem, vagy csak alacsony szinten figyelhető meg a forrás porcsejtek zónájában, illetve az epifízeális porcban (C,F,I,K,L). Magasabb szintű expresszió detektálható az ujjakban (D,E,H,J), mint a kar fejlődő hosszú csontjaiban $(\mathrm{C}, \mathrm{F}, \mathrm{I}, \mathrm{K}, \mathrm{L})$. A gerinc farki régiójában $(\mathrm{O}, \mathrm{R})$ intenzívebb festődést tapasztalunk, mint a deréktáji $(\mathrm{N}, \mathrm{Q})$ és nyaki (M,P) csigolyákban. Látható még transzgén kifejeződés a fejlödő bordákban $(\mathrm{U})$, az orrporcban $(\mathrm{S}, \mathrm{T})$. Méretvonal 2 mm (B), $200 \mu \mathrm{m}$ (C-U). További jelölések: ld. 5,7. ábrák.

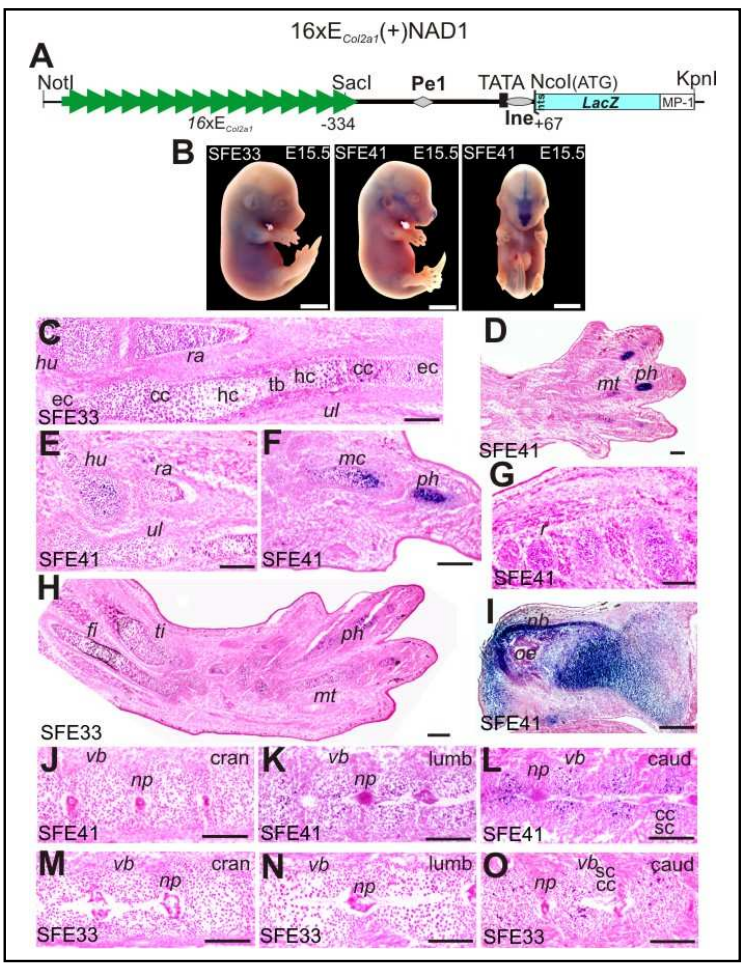

14. ábra A Col2a1 enhancer 16 kópiája és a matrilin-1 rövid promoter által irányított transzgénre is a matrilin-1 kifejeződési mintázata jellemző. A $16 \mathrm{xE}_{\mathrm{Col2a1}} \mathrm{NAD} 1$ transzgén térképe (A) és expressziós mintázata (B). A hisztológiai vizsgálat során kiderült, hogy a transzgén aktivitás az ujjakban a legerősebb (D,F), és gyengébb a humerusban, radiusban, ulnában (C,E), illetve tibiában és fibulában (H). Nem detektálható expresszió a nyaki csigolyatestekben (J,M), míg a deréktáji csigolyák tartalmaznak néhány festődő sejtet $(\mathrm{K}, \mathrm{N})$. A legerősebb festődés a farki csigolyákban észlelhető $(\mathrm{L}, \mathrm{O})$. Nagyon intenzív expresszió figyelhetô meg az orrporcban és a környező szövetekben (I), illetve gyengébb festődés látható még a bordákban $(\mathrm{G})$. Méretvonal $2 \mathrm{~mm}$ (B), $200 \mu \mathrm{m}$ (C-O). További jelölések: ld. 5,7. ábrák. 
A növekedési korongon belül szintén a matrilin-1 génre jellemző zonális expressziós mintázat figyelhető meg, tehát a festődő sejtek a fejlődő hosszú csontok proliferatív és prehipertróf zónáiban vannak, míg a kondenzálódott mesenchyma, a forrás, a hipertróf, az epifízeális porcsejtek, valamint a perichondrium sejtjei egyáltalán nem festődnek (13. ábra $\mathrm{C}, \mathrm{F}, \mathrm{I}, \mathrm{K}, \mathrm{L}, \mathrm{O}, \mathrm{R})$.

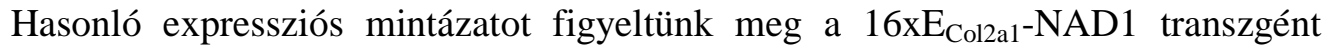
hordozó embriók vizsgálata során is, mivel az enhancer még 16 kópiában sem volt képes a Col2al génre jellemző expressziós mintázat kialakítására (14. ábra).

Ezen adatok alapján arra következtetünk, hogy bár a matrilin-1 gén rövid promotere önmagában alacsony aktivitású, müködéséhez homológ, vagy heterológ pozitív DNS elemek szükségesek. A rövid promoter jelenléte azonban mégis képes felülírni egy heterológ, rendkívül erős, általános porcspecifikus enhancer működését. A matrilin-1 rövid promoter gátolja a Col2al enhancer müködését a proximális struktúrákban, és aktivitását a növekedési korong meghatározott zónáiba irányítja. Tehát a rövid promoteren lévő konzervált DNS elemeknek meghatározó szerepük van a matrilin-1 gén szövettípusra, fejlődési állapotra és disztális vázelemekre specifikus expressziójának irányításában.

\section{A rövid promoter szabályozó elemeit érintő mutációk hatása a matrilin-1 génexpresszióra}

\subsection{A Pe1 elem Sox kötőhelyeinek mutációja megszünteti a hosszú promoter aktivitását porcsejtekben}

A továbbiakban azt kívántuk megvizsgálni, hogy a rövid promoteren korábban azonosított, különböző mértékben konzervált DNS elemek milyen módon járulnak hozzá a matrilin-1 gén szövet- és fejlődési állapotspecifikus működésének szabályozásához in vivo.

Ennek érdekében először az amniota fajokban legnagyobb homológiát mutató Pe1 elemet [80] kezdtük vizsgálni. A Pe1 elem a TATA boxtól 100-200 bp távolságra, 5' irányban helyezkedik el. Az elem két, egymással szemben álló motívumot tartalmaz, melyek nagyfokú homológiát mutatnak a Sox9 kötőhellyel [110]. Ezeket a motívumokat két nukleotid választja el egymástól. 
A Pe1 elem szerepét először tranziens expressziós kísérletekben vizsgáltuk, melyekhez olyan konstrukciókat hoztunk létre, amik a Sox9 kötőhelyekben, illetve az azokat elválasztó nukleotidokban hordoztak pontmutációkat (15. ábra D). Korábbi adatok rendelkezésre álltak e mutációk rövid promoterre gyakorolt hatásáról. A Pe1M1 mutáció a páros Sox9 motívumot zavarja meg, ami a rövid promoter aktivitását felére csökkentette, míg a Pe1M4 mutáció a két ismétlődő Sox9 motívum közötti spacer régiót érinti, ami szintén aktivitáscsökkenést okozott chondrocytákban [126]. CEF és HDM kultúrákban nem volt jelentős változás, ami arra utal, hogy a Pe1 elemnek szerepe van a matrilin-1 gén szövet- és fejlődési állapotspecifikus aktivitásában.

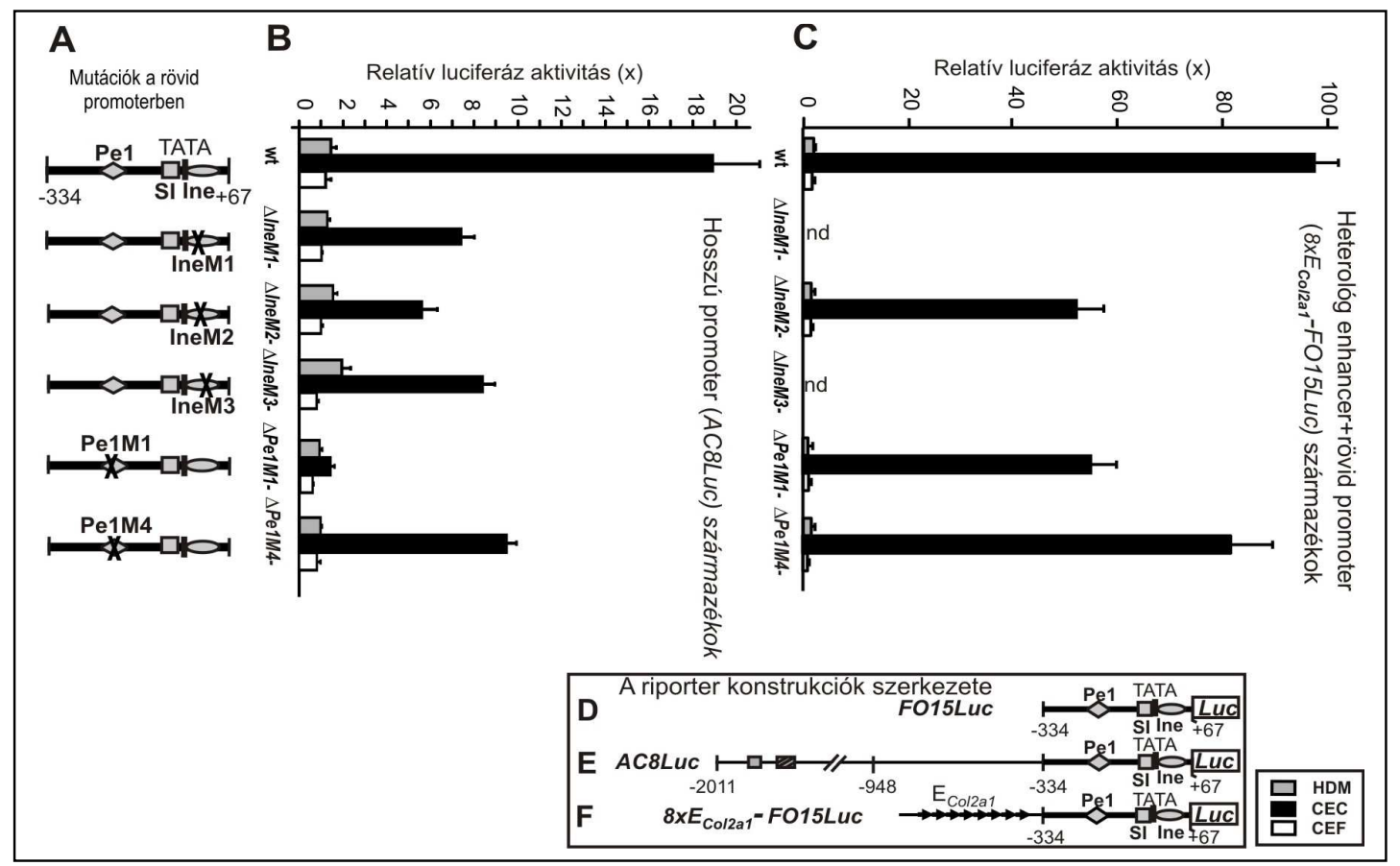

15. ábra Az Ine és Pe1 elemek mutációinak hatása a matrilin-1 hosszú promoter, illetve a 8xE $\mathrm{Col2a1}_{\text {és a }}$ rövid promoter által irányított konstrukciók aktivitására tranziens expressziós kísérletben. A mutációk helyzete a rövid promoterben (A), hatásuk a hosszú promoter (AC8-Luc) aktivitására (B), illetve a heterológ enhancert és a rövid promotert tartalmazó konstrukciók (8xE $\mathrm{Col2a1}_{\mathrm{a}}$-FO15-Luc) aktivitására (C) HDM, CEC és CEF sejtkultúrákban. A Pe1 elem és mutáns változatainak szekvenciája (D). A riporter konstrukciók teljes térképe (E,F). A diagramok a konstrukciók AC8-Luc-hoz és 8xE $\mathrm{Col2a}_{1}$-FO15-Luc-hoz viszonyított relatív aktivitását mutatják.

Ezeknek a pontmutációknak a hatását megvizsgáltuk a hosszú promoter (15. ábra B), illetve a nyolckópiás Col2al enhancer elem és a rövid promoter által hajtott konstrukciók tranziens expressziós aktivitására is (15. ábra C). Mindkét esetben drámai aktivitáscsökkenést tapasztaltunk. A Pe1M1 mutáció a hosszú promoter aktivitását kevesebb, mint tizedére csökkentette, a Col2al enhancer és a rövid promoter által irányított konstrukcióét pedig közel felére. A Pe1M4 mutáció a hosszú promoter 
aktivitását felére csökkentette, a heterológ enhanceres konstrukció működésére kevésbé volt hatással (15. ábra B,C).

A tranziens expressziós adatok alapján az a következtetés vonható le, hogy a Sox motívumok mutációja a távoli elemek jelenlétében is gátolja a promoter aktivitását, csökkenti a távoli elemek aktiváló hatását. Tehát a Pe1 elemhez kötődő Sox9-nek kulcsszerepe van a matrilin-1 gén müködésének szövetspecifikus szabályozásában. Az említett aktivitásváltozások a másik két sejtkultúrában nem voltak megfigyelhetők.

A tranziens expresszió adatok alapján úgy gondoltuk, hogy a Pe1M1 mutáció in vivo is rendkívül nagymértékü aktivitáscsökkenést okozhat, ami transzgenikus egerekben nem detektálható. Ezért transzgenikus egerek készítéséhez azt a konstrukciót használtuk, amelyben a hosszú promoter a Pe1M4 mutációt hordozza, tehát a páros Sox kötőhely egyik motívumát rontja el (16. ábra A), mert valószínűnek tartottuk, hogy ennek aktivitását hisztológiai módszerekkel detektálni tudjuk.

Az injektálás után izolált embriók hisztológiai vizsgálata során kiderült, hogy a Pe1 elem spacer régióját érintő mutáció nem befolyásolta jelentősen a transzgén expressziós szintjét, mivel a három vizsgált embrió tengely- és végtagvázának minden elemében magas szinten kifejeződött (16. ábra B-Z). A mutáció a zonális kifejeződési mintázatra sem volt hatással, mivel a növekedési korong oszlopos proliferatív és prehipertróf zónáira korlátozódott (16. ábra D,E,G-J). Ugyanakkor a fejlődő végtagváz proximális struktúrái (pl. humerus, radius, ulna) (16. ábra C,F,K,L) ebben az esetben nem mutattak gyengébb festődést, mint a disztális vázelemek (pl. ujjak) (16. ábra E,G,H,J). Ez azt bizonyítja, hogy a mutáció megszüntette, vagy jelentősen csökkentette a transzgén müködés gátlását a proximális vázelemekben. Ugyanakkor a tengelyvázban a proximo-disztális különbségek megmaradtak (16. ábra M-X), bár a különbség a craniális és caudális elemek között csökkent, tehát más DNS elemek felelősek a tengelyváz és a végtagváz proximális elemeiben a génexpresszió gátlásáért.

Ezekből az adatokból arra következtetünk, hogy a Pe1 elem spacer régiójához kötődő, eddig azonosítatlan, valószínüleg egy Sox partnerfaktor felelős a matrilin-1 gén proximo-disztális irányítottságú kifejeződéséért a végtagvázban. Valószínűleg ehhez az elemhez kötődő faktornak van szerepe az expresszió gátlásában a proximális vázelemekben. 


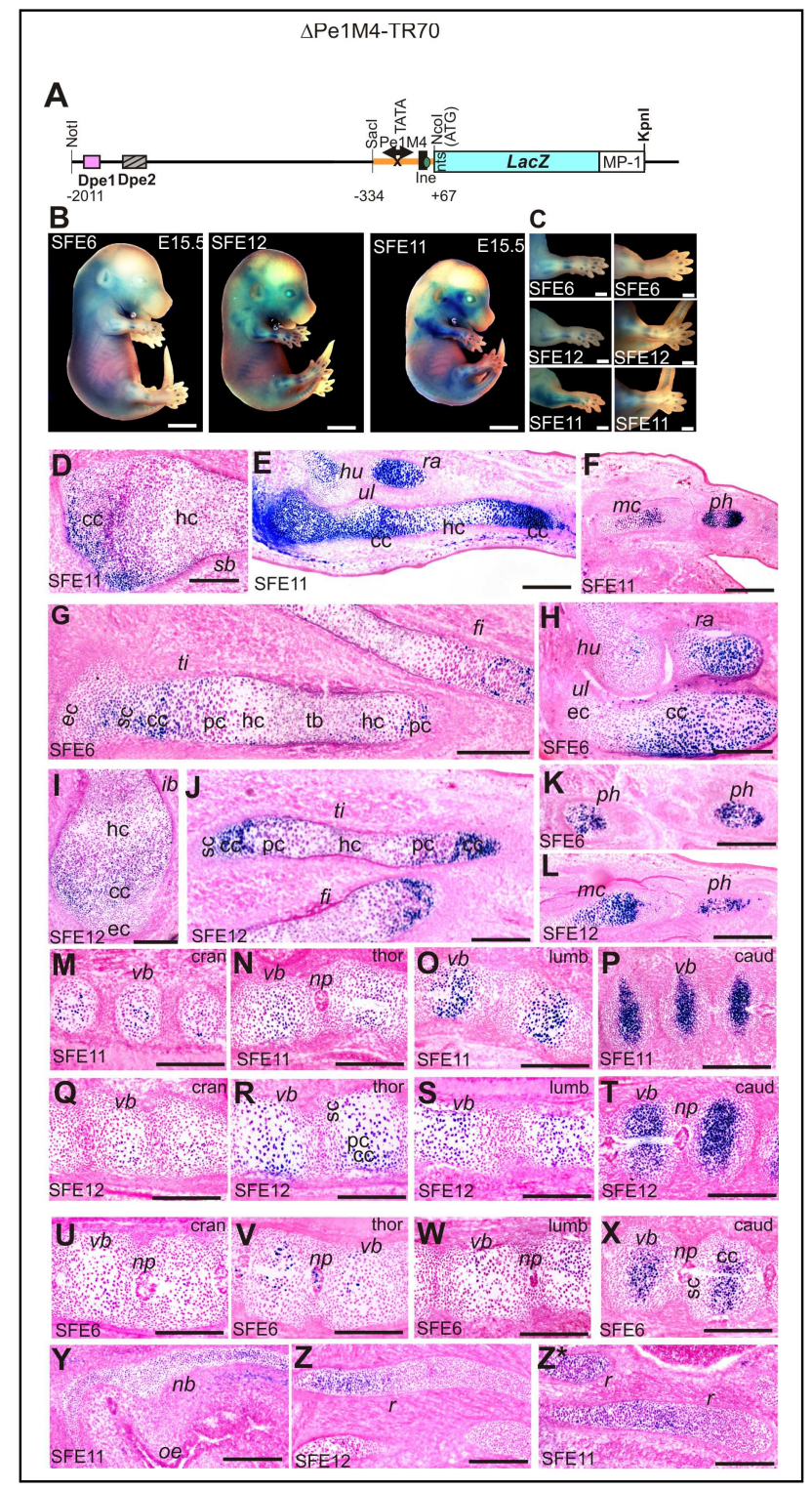

16. ábra A $\Delta$ Pe1M4 mutáció nem befolyásolja a transzgén zonális aktivitását, viszont a végtagváz elemeiben megszünteti a proximo-disztális irányultságot. A $\Delta$ Pe1M4-TR70 transzgén térképe (A) és kifejeződési mintázata az X-Gal festett alapító embriók vázelemeiben (B,C). A fagyasztott metszetek hisztológiai analízise alátámasztotta az egyformán magas szintű LacZ expressziót a fejlődő végtagváz függesztő öveiben (D,I) és hosszú csontjaiban (E,G,H,J), valamint az ujjakban (F,K,L). A növekedési korongokban az expresszió az oszlopos proliferatív és prehipertróf zónákra korlátozódik. A tengelyváz elemeiben viszont megmaradt a proximo-disztális irányultság, mivel a craniális (M,Q,U), thorakális (thor) $(\mathrm{N}, \mathrm{R}, \mathrm{V})$ és lumbális $(\mathrm{O}, \mathrm{S}, \mathrm{W})$ csigolyatestekben a festődés kisebb mértékü, mint a caudális $(\mathrm{P}, \mathrm{T}, \mathrm{X})$ csigolyák sejtjeiben. Látható még transzgén expresszió az orrporcban (Y) és a bordákban (Z,Z*). Méretvonal $2 \mathrm{~mm}$ (B,C), $200 \mu \mathrm{m}$ (D-Z*). További jelölések: ld. 5,7. ábrák. 
Mivel szerettük volna azt a faktort meghatározni, ami a Sox9-en kívül a Pe1 elemhez kötődik, „pull down” kísérleteket végeztünk. Ehhez biotinilált Pe1 oligonukleotidokat rögzítettünk mágneses gyöngyökhöz, melyeket chondrocyta sejtkivonattal inkubáltunk. A kivonatból a Pe1 elemhez kötődött fehérjék közül MALDI tömegspektrometriával sikerült azonosítani az aggrekán promoterkötő fehérjét (APBP), melynek felismeröhelyét in silico analízis során több példányban is megtaláltuk a matrilin1 szabályozó régióban. Adatainkból arra következtetünk, hogy a Sox9 faktoron kívül APBP és más, a proximo-disztális szabályozásban szerepet játszó, feltehetően morfogén hatású transzkripciós faktorok is részt vesznek a matrilin-1 gén szükített porcspecifikus kifejeződésének szabályozásában.

\subsection{Az Ine elem Sox kötőhelyeinek szerepe}

Amnioták matrilin-1 génjein végzett korábbi in silico analízis során a rövid promoteren a Pe1-nél egy kevésbé konzervált szabályozó elem jelenlétére is fény derült [80]. A csirke génben ez a szekvencia kevésbé konzervált, viszont tartalmaz két, egymással ellentétes irányban elhelyezkedő Sox kötőhelyet. Az Ine elem tartalmazza a csirke matrilin-1 gén első transzkripciós startpontját is (17. ábra A). Korábbi in vitro EMSA kísérletek igazolták, hogy chondrocyta sejtmagi fehérjékkel az Ine elem három komplexet képez (I-III.), melyek közül kettő (I., II.) Sox9, L-Sox5 és Sox6 antitestekkel supershift-et mutat, illetve Sox9, HMG és $E_{\text {Col2a1 }}$ próbákkal kompetálható [111]. Ezek a komplexek valószínüleg tartalmazzák a Sox trió tagjait, míg a harmadik komplex (III.) nem porcspecifikus, nem tartalmaz Sox faktorokat.

Az Ine elem Sox motívumainak pontosabb behatárolására további EMSA kísérleteket végeztünk tisztított Sox faktorok kötődésének igazolása végett. Ehhez az elem különböző mutáns, illetve rövidített változatait állítottuk elő (17. ábra A). GST fúziós SOX9, L-Sox5 és Sox6 fehérjék kötődését vizsgáltuk ezekhez az oligonukleotidokhoz. Négy különböző pontmutációt hordozó konstrukció már korábban rendelkezésünkre állt [111]. Az IneM1 és IneM3 oligonukleotidok a Sox kötőhelyek egyikében tartalmaztak pontmutációkat, míg az IneM2 és IneM5 mindkét Sox kötőhelyet elrontotta. Ezekkel az elemekkel végzett EMSA kísérletekben azt tapasztaltuk, hogy az IneM2 és IneM5 mutációk gátolják a komplexképződést a SOX9 fehérjével, illetve nagymértékben csökkentik az L-Sox5 esetében (17. ábra). Az IneM1 és IneM3 mutációk sokkal kisebb hatást gyakoroltak a komplexképződésre (17. ábra), az IneM1 mutáció inkább a Sox9, az 
IneM3 mutáció inkább az L-Sox5 kötődését csökkentette. Annak igazolására, hogy mindegyik Sox motívum részt vesz a kötésben, az elem rövidített változatain (Ine5'h1, Ine5'h2, Ine3'h1) is megvizsgáltuk a komplexképződést. Azt tapasztaltuk, hogy különböző intenzitással, de az elem 5' és 3' végén lévő Sox motívumok is képeznek komplexet a Sox trió tagjaival (17. ábra).

Ezekből az adatokból arra következtetünk, hogy az Ine elemen lévő mindkét Sox kötőhely funkcionális és kooperatívan kötik a Sox faktorokat, azaz a megfelelö génmüködéshez ezek együttmüködésére van szükség.

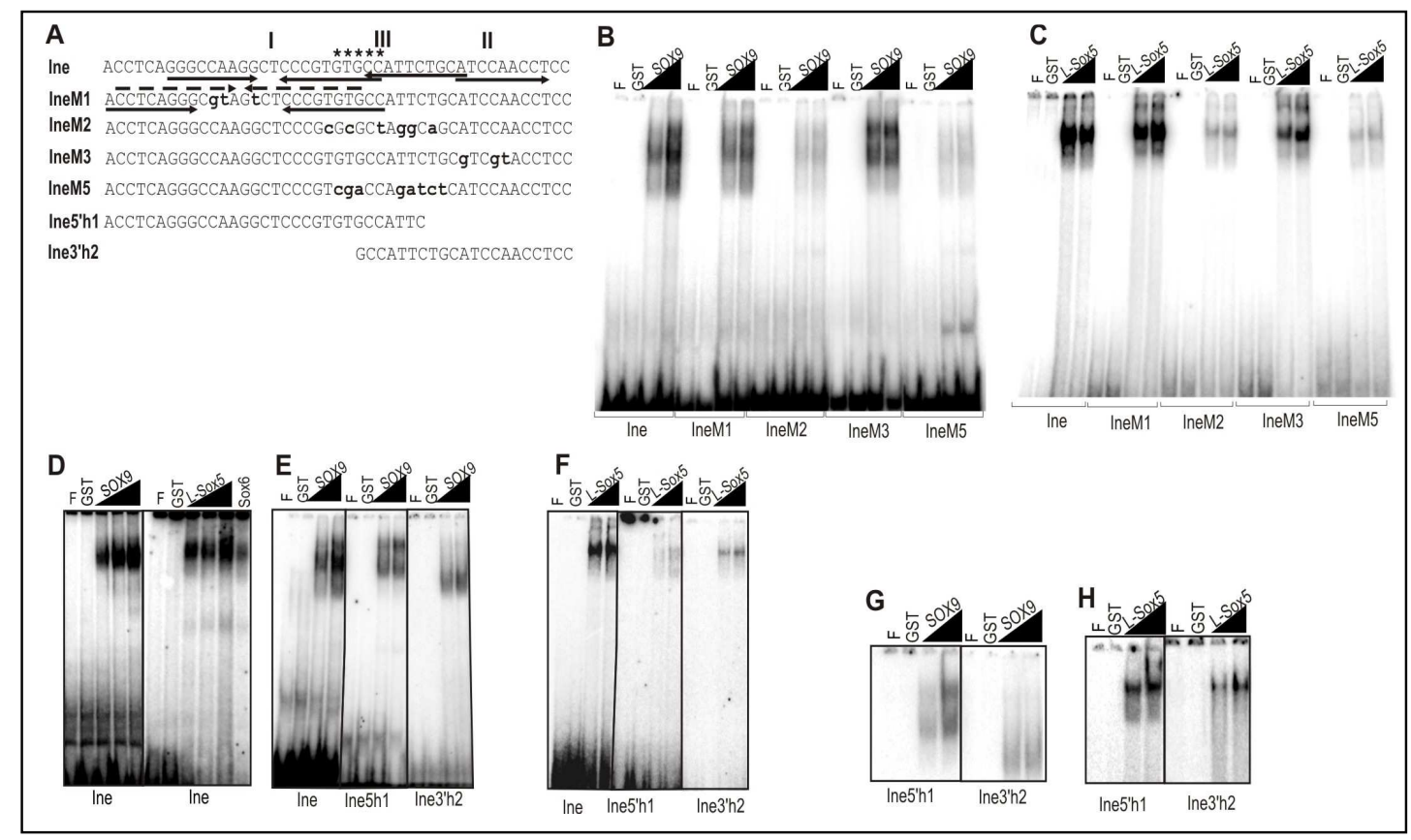

17. ábra Tisztított Sox fehérjék kötődése az Ine elemhez in vitro. Az Ine elem és mutáns, illetve rövidített változatainak szekvenciái (A). Tisztított GST-fúziós Sox fehérjék nukleoprotein komplexeket képeznek az Ine elemmel, annak mutáns és rövidített változataival EMSA kísérletekben. Az M2 és M5 mutációk, amik mindkét Sox kötőhelyet érintik megakadályozták a komplexképződét, míg az M1 és M3 mutációk, amik csak az egyik Sox motívumot rontják el, kevésbé voltak hatással a komplexképződésre (B,C). Az 5' végi Sox motívum a Sox9-et preferálta (E), míg a 3' végi motívumhoz inkább az L-Sox5/Sox6 kötődött.

Az Ine elem mutáns változatainak (IneM1, IneM2, IneM3) hatását tranziens expressziós kísérletekben is megvizsgáltuk. Ehhez olyan konstrukciókat hoztunk létre, melyekben a luciferáz riporter gént a teljes hosszúságú matrilin-1 promoter, illetve a nyolckópiás Col2al enhancer elem a rövid promoterrel együtt irányítja (15. ábra). Mindhárom mutáció legalább a felére csökkentette a porcsejtekben mért aktivitást a hosszú promoter, illetve a heterológ enhancer-rövid promoter konstrukciók esetében is. 
Ezek az adatok is azt támasztják alá, hogy a Sox faktorok kötődése az Ine elem konzervált helyeihez szintén nélkülözhetetlen a promoter teljes aktivitásához.

Ezen adatok alapján két Ine mutáns konstrukciónak készítettük el a transzgenikus egerek előállításához alkalmas változatát. A $\Delta$ IneM1-TR70 transzgént (18. ábra A) hordozó egerekből készült fagyasztott metszetek hisztológiai vizsgálata arra utalt, hogy az Ine elem 5' Sox motívumát megzavaró mutáció nagymértékben lecsökkentette a transzgén expressziót a fejlődő vázelemekben, de még mindig megfigyelhető volt bizonyos, a TR70 transzgénéhez hasonló proximo-disztális eltérés (18. ábra M-U). Továbbá a növekedési korongon belül a festődés még mindig a proliferatív és prehipertróf zónákra korlátozódott (18. ábra G,H,J). Ebböl arra következtetünk, hogy az Ine elem 5' Sox kötőhelye nélkülözhetetlen szerepet játszik a promoter megfelelő aktivitásában in vivo.

Az előzővel ellentétben a $\Delta$ IneM2-TR70 transzgént (19. ábra A) hordozó egerekben a hisztológiai vizsgálat során a várthoz képest magasabb szintű transzgén expressziót detektáltunk a tengely- és végtagváz összes elemében (19. ábra B). Amellett, hogy ebben az esetben is lecsökkent a génkifejeződés proximo-disztális irányítottsága a végtagvázban (19. ábra C,D-I,K-M), de megmaradt a tengelyvázban (19. ábra P-U). Érdekes módon a vizsgált három embrió közül kettőben az expresszió posztero-anterior irányban megnőtt. Ez jól látszik, ha összehasonlítjuk a festődés intenzitását a radiusban és az ulnában (19. ábra B-G), valamint a hüvelyk- és kisujjban (19. ábra B,C,J). Ez arra utal, hogy az anterior struktúrákban megszűnhetett egy gátló mechanizmus, ami addig akadályozta a magas szintü expressziót. Ebből arra következtetünk, hogy a mutáció az Ine Sox motívumokon kívül még egy morfogén hatású gátló faktor kötődését is megakadályozhatta az Ine elemen. Viszont nem zárhatjuk ki, hogy az integrációs hely eredményezte a poszterior elemekben a gátlás feloldását. 


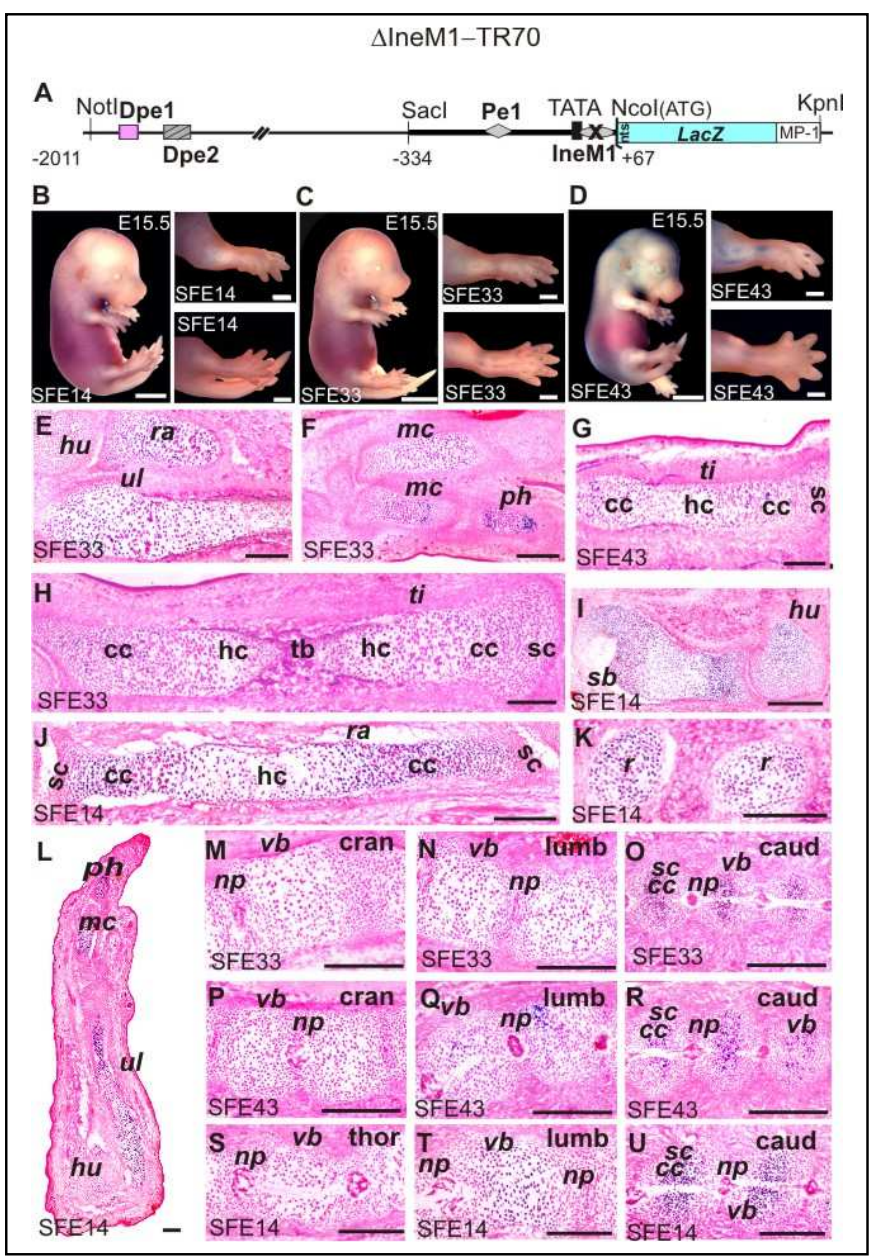

18. ábra A $\Delta$ IneM1-TR70 transzgén alacsony zonális aktivitást mutat. A transzgén térképe (A) és expressziós mintázata az alapító embriók vázelemeiben (B-D). Alacsony szintű X-Gal festődés figyelhető meg a fejlődő lapockában (I) és a végtagok hosszú csontjaiban (E,G,H,J,L), amely az ujjak $(\mathrm{F}, \mathrm{L})$ irányába kismértékben erősödik. A proximo-disztális különbségek jobban láthatók a tengelyváz esetében, mivel a caudális $(\mathrm{O}, \mathrm{R}, \mathrm{U})$ csigolyatestekben a LacZ expresszió mértéke sokkal nagyobb, mint a craniális $(\mathrm{M}, \mathrm{P}, \mathrm{S})$ és lumbális $(\mathrm{N}, \mathrm{O}, \mathrm{T})$ csigolyatestekben. Erősebb festődés figyelhető meg a növekedési korongok oszlopos proliferatív és prehipertróf zónáiban $(\mathrm{G}, \mathrm{H}, \mathrm{J})$. Alacsony szintű expresszió detektálható még a bordákban (K). Méretvonal 2 mm (B-D), $200 \mu \mathrm{m}$ (EU). További jelölések: ld. 5,7. ábrák.

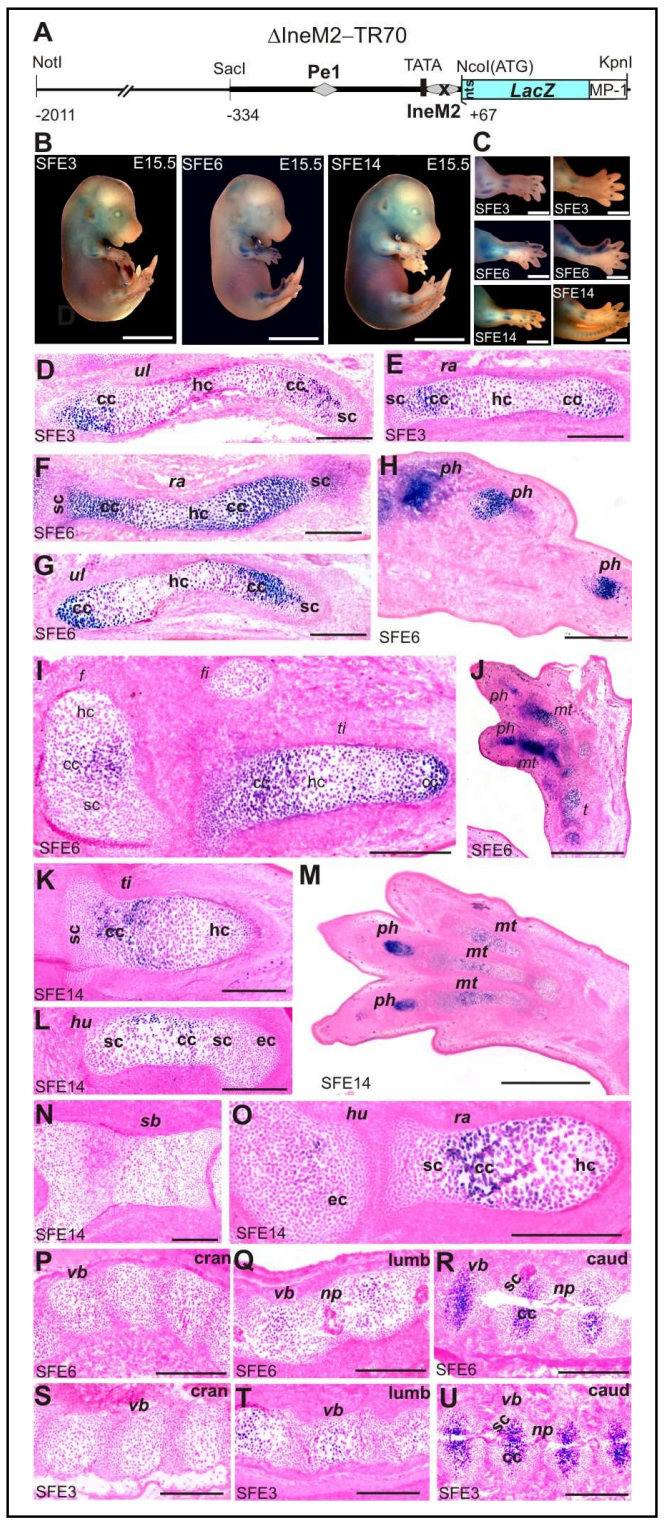

19. ábra Az IneM2 mutáció csökkenti a génkifejeződés proximo-disztális irányítottságát a végtagvázban. A $\Delta$ IneM2-TR70 transzgén térképe (A) és a vártnál magasabb expressziós szintje az alapító embriókban (B,C). A hisztológiai vizsgálat azt mutatta, hogy a végtagváz elemeiben csökkent a kifejeződés proximo-disztális irányultsága, mivel a mellső (D-G,L,O) és hátsó végtagok $(\mathrm{I}, \mathrm{K})$ hosszú csontjai és az ujjak $(\mathrm{H}, \mathrm{J}, \mathrm{M})$ hasonló mértékben festődnek. A tengelyváz esetében viszont megmaradt a proximo-disztális irányítottság, mivel a nyaki $(\mathrm{P}, \mathrm{S})$ és a deréktáji $(\mathrm{Q}, \mathrm{T})$ csigolyákban az expresszió szintje sokkal alacsonyabb, mint a farki (R,U) csigolyatestekben. Érdekes módon a három embrió közül kettőben az expresszió posztero-anterior irányban megnőtt. Ez jól látszik, ha összehasonlítjuk a festődés intenzitását a radiusban és az ulnában (D-G), valamint a hüvelyk- és kisujjban (J). Méretvonal 2 mm (B,C), $200 \mu \mathrm{m}$ (D-U). További jelölések: ld. 5,7. 


\section{Távoli homológ reguláló elemek szerepe a matrilin-1 gén exprssziójának szabályozásában}

\subsection{Disztális elemek hatása a rövid promoter aktivitására}

A konzervált Dpe1 és Dpe2 elemeket hordozó -2011/-1394 fragmentum a rövid promoter aktivitását viszonylag jelentősen növelte, de a rövidített fragmentum (-2011/1741) már nem aktivált tranziens expressziós kísérletekben (7. ábra). Ezek alapján valószínűnek látszott, hogy a Dpe1 és Dpe2 szerepet játszhat a promoter aktivitásában.

A távoli elemek szerepének igazolására olyan konstrukciókat hoztunk létre tranziens expressziós kísérletekhez, melyekben a Dpe1 elem 1,2, 3, 4, illetve 8 kópiában szerepelt a luciferáz riporter gén előtt (20. ábra). Az elemek számának növelésével a CEC kultúrában mért expressziós szint a rövid promoter aktivitásához képest drámaian megnövekedett, a 8 kópia hatására annak közel 30-szorosára. A másik két vizsgált sejttípusban az aktivitás nem mutatott jelentős változást. Mindez az elem specifikus müködését bizonyította a késői proliferatív chondroblastokban gazdag kultúrában.

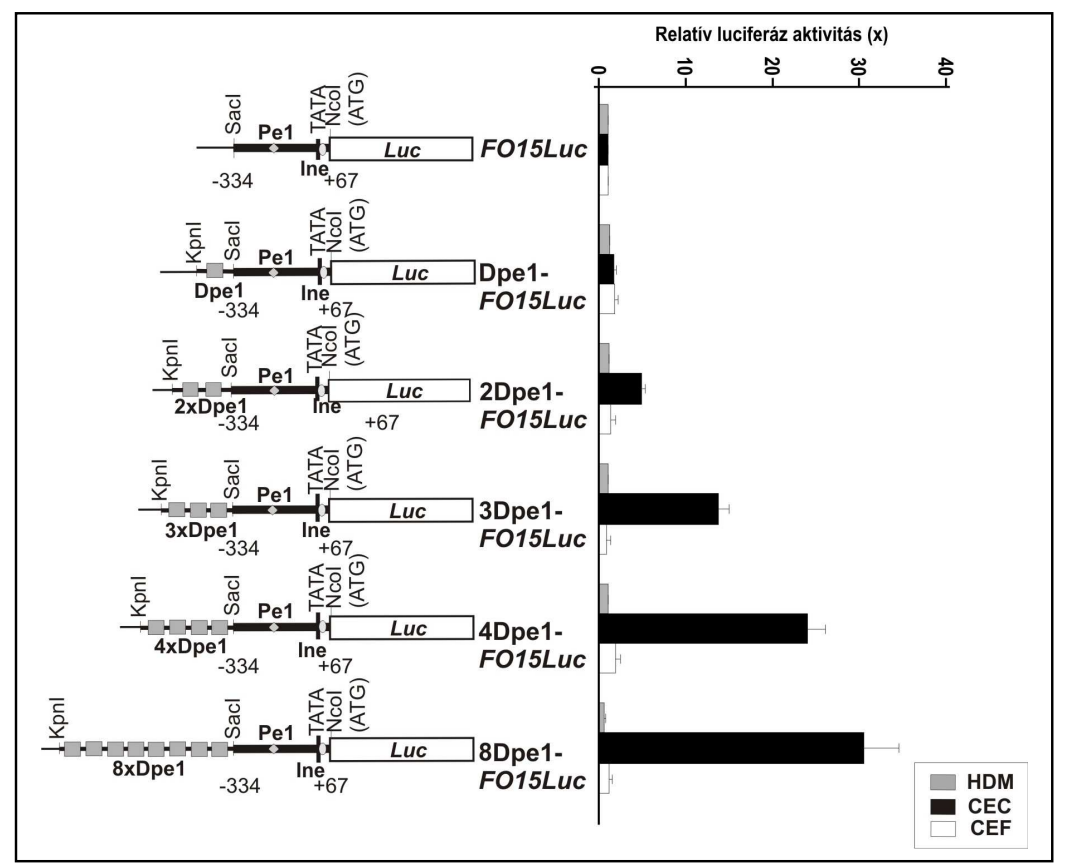

20. ábra A matrilin-1 távoli elemének (Dpe1) különböző számú kópiáinak hatása a rövid promoter aktivitására tranziens expressziós kísérletben. A diagram az egyes konstrukciók FO15-Luc-hoz viszonyított relatív aktivitását mutatja HDM, CEC és CEF kultúrákban. 
A Dpe2 elemmel létrehozott hasonló konstrukciók vizsgálata során viszont azt tapasztaltuk, hogy ez az elem a rövid promoter aktivitását több kópiában sem növeli számottevően (21. ábra). Amikor a magas aktivitást biztosító nyolckópiás Dpe1 elemet tartalmazó konstrukciót a Dpe2 elem különböző számú kópiáival egészítettük ki, chondrocyta kultúrában jelentős aktivitáscsökkenést tapasztaltunk, ami a Dpe2 elemek számának növelésével egyre kifejezettebb volt. A gátlás még kifejezettebb volt, amikor a konstrukció kevesebb számú Dpe1 elemet tartalmazott. Ebből arra következtettünk, hogy a Dpe elemek egymással és a rövid promoterrel együttmüködve szerepet játszanak a matrilin-1 gén szövet- és differenciálódási stádium specifikus kifejeződésének irányításában.

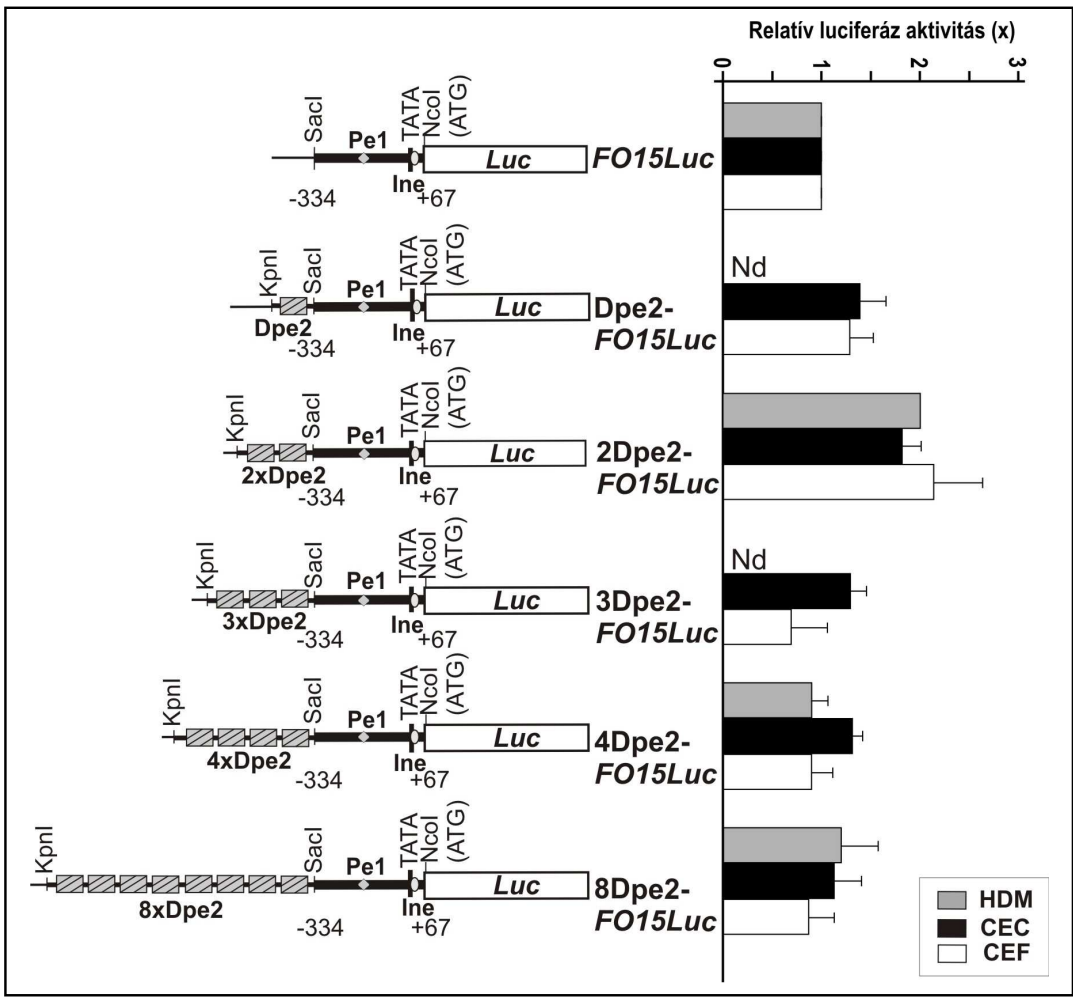

21. ábra A matrilin-1 távoli elemének (Dpe2) különböző számú kópiáinak hatása a rövid promoter aktivitására tranziens expressziós kísérletben. A diagram az egyes konstrukciók FO15-Luc-hoz viszonyított relatív aktivitását mutatja HDM, CEC és CEF kultúrákban.

Hogy a Dpe elemek hatását in vivo is megvizsgáljuk, először a 8xDpe1-FO15-Luc konstrukciónak készítettük el a LacZ riporter gént tartalmazó verzióját (22. ábra A), mivel a tranziens expressziós kísérletekben ez mutatta a legmagasabb porcspecifikus aktivitást. Az öt megvizsgált transzgenikus embrióban rendkívül magas expressziós szintet figyeltünk meg az összes endochondrális csontosodással kialakuló vázelemben (22. ábra 
B). Mindez a TR70-nél is kifejezettebb proximo-disztális irányítottsággal párosult. Nem csak a gerinc és a végtagváz esetében (22. ábra C-I, M-S), hanem a végtagváz egyes elemein belül is jól megfigyelhető volt. Így például a hosszú csontok és az ujjpercek disztális végein az expresszió sokkal nagyobb mértékủ volt, mint a proximális végeken (22. ábra C-J,M). A transzgén kifejeződési mintázatára jellemző még, hogy az erőteljes proximo-disztális irányítottság a disztális epifízisekben a zonális kifejeződési mintázatot is módosította, így az ujjpercek disztális végein a proliferatív és prehipertróf zónák mellett a forrás zóna és a perichondrium sejtjei is igen erősen festődtek (22. ábra D,G,I-M). Egyetlen embrió esetében tapasztaltunk ektopikus kifejeződést az intramembrán úton kialakuló koponyatetőcsontban (22. ábra B). Ez arra utal, hogy a transzgén expressziós mintázatát az integrálódási hely genomi környezete nem befolyásolja lényegesen.

A tranziens expressziós és transzgenikus egér kísérletek eredményei alapján elmondható, hogy a Dpe1 elem meghatározó szereppel bír a matrilin-1 gén szövet- és fejlődési állapotspecifikus aktivitásának, illetve proximo-disztális irányítottságának kialakításában, ezáltal alkalmas lehet arra, hogy egyéb fuzionált gének kifejeződését az ízületi betegségek (rheumatoid arthritis) által legérintettebb disztális struktúrákba (ujjak) irányítsa. Ezért ezzel a konstrukcióval transzgenikus egérvonalat hoztunk létre, ami alkalmas arra, hogy indukált arthritisben nyomon kövessük a génexpresszió csökkenését, illetve a gyógyszerjelölt vegyületekkel való kezelés utáni regenerációt. A 8xDpe1-NAD1 vektorra és alkalmazására transzgenikus egerekben szabadalmat nyújtottunk be.

Ezután arra voltunk kíváncsiak, hogy a Dpe2 elem deléciója a hosszú promoterből hogy befolyásolja annak aktivitását in vivo. Ebből a célból eltávolítottuk a -1740/-1642 DNS szakaszt a promoter fragmentumból és így építettük a $L a c Z$ riportergén elé. A $\Delta$ Dpe2-TR70 transzgént (23. ábra $\mathrm{A})$ expresszáló embriók vizsgálata során azt tapasztaltuk, hogy a festődés intenzitása összehasonlítható a TR70 transzgénével, sőt megmaradt a zónaspecifikus aktivitás is, hiszen a növekedési korongok proliferatív és prehipertróf zónáira korlátozódott az expresszió, ahogy az a végtagok hosszú csontjaiban megfigyelhető (23. ábra C,D,F,H,I,L). Lényeges különbség viszont a TR70 transzgénhez képest, hogy míg a tengelyváz esetében megmaradt a proximo-disztális irányítottság (azaz a nyaki régiótól a farki régió felé haladva a fejlődő csigolyatestekben nagymértékben nőtt az expresszió szintje) (23. ábra O-T), addig ez a fejlődő végtagváz elemeiben megszünt. Ezt támasztja alá, hogy hasonló mértékủ $L a c Z$ expressziót figyeltünk meg mind a mellső (humerus, radius, ulna) (23. ábra C,D,F), mind a hátsó végtag fejlődő hosszú csontjaiban (femur, tibia, fibula) (23. ábra H,I,L), valamint az ujjakban (23. ábra E,G,I,M). A 
végtagváz proximális struktúráiban jelentős mértékben megnövekedett transzgén expresszió arra utal, hogy a Dpe2 elem deléciója egy represszáló hatást szüntetett meg ezekben a struktúrákban. Ez alapján feltételezhető, hogy a Dpe2 elemhez olyan transzkripciós faktorok, vagy morfogének kötődnek, melyeknek negatív szabályozó szerepük van a matrilin-1 gén kifejeződésének szabályozásában a végtagok proximodisztális tengelye mentén.

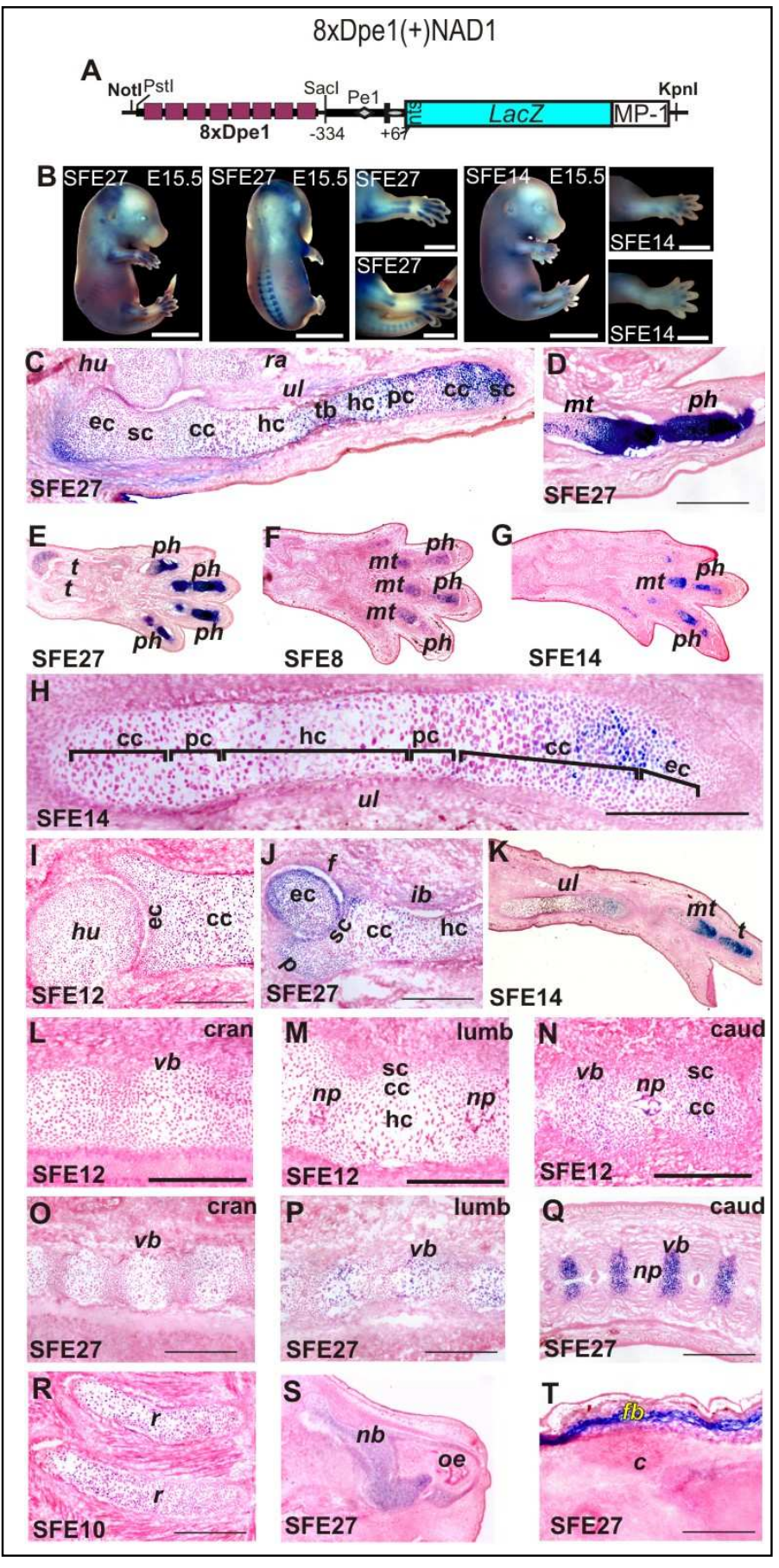

22. ábra A Dpe1 elem nyolc kópiája nagymértékben növeli a rövid promoter aktivitását és az expressziót a disztális struktúrákba irányítja. A 8xDpe1-NAD1 transzgén térképe (A). Az X-gal festett alapító embriók chondrocraniumában, tengely- és végtagvázában figyelhető meg különbözö intenzitású festődés, mely a váz disztális struktúráiban a legerősebb (B). A metszetek hisztokémiai vizsgálata erős festődést mutat a fejlődő ulna (C,J), humerus (E) és radius $(F)$ oszlopos proliferatív és prehipertróf porcsejtjeiben. Az ujjakban megfigyelhetö festődés (D,G-I,M) intenzívebb, mint a végtagok hosszú csontjaiban (C,E,F,J,M), illetve a mellső és hátsó végtagok függesztő öveinek fejlődő elemeiben (K,L). A hosszú csöves csontok és az ujjak disztális végein a festődés sokkal erősebb, mint a proximális végeken $(\mathrm{C}-\mathrm{J}, \mathrm{M}) . \quad \mathrm{Az}$ expresszió proximo-disztális erősödése a tengelyváz esetében is látható. A fejlődő farki csigolyák porcsejtjei $(\mathrm{P}, \mathrm{S})$ sokkal intenzívebben festődnek, mint az ágyéki $(\mathrm{O}, \mathrm{R})$ és a nyaki csigolyák (N,Q) sejtjei. Megfigyelhető még transzgén expresszió a bordákban $(\mathrm{T}, \mathrm{V})$ és az orrporcban (U). Méretvonal $2 \mathrm{~mm}$ (B), $200 \mu \mathrm{m}$ (C-V). További jelölések: ld. 5,7. ábrák. 


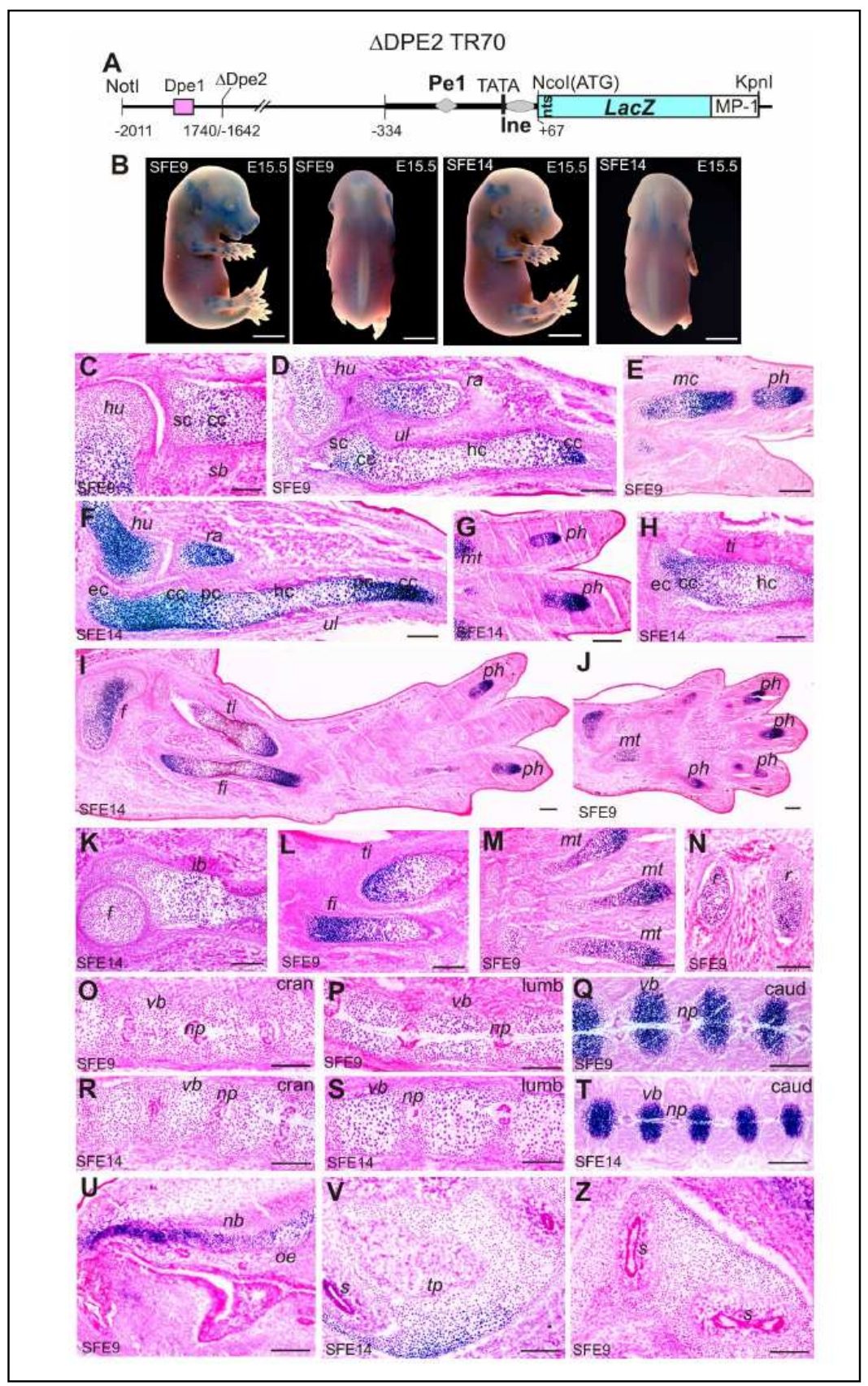

23. ábra A Dpe2 elem deléciója nem befolyásolja a zóna-specifikus expressziót, de a hosszú csontokban megszünteti a proximo-disztális irányítottságot. A $\triangle \mathrm{Dpe} 2-\mathrm{TR} 70$ transzgén térképe (A) és kifejeződési mintázata az alapító embriók fejlődő vázelemeiben (B). A fagyasztott metszetek hisztológiai vizsgálata során kiderült, hogy a transzgén expresszió a fejlödő hosszú csontok növekedési korongjának oszlopos proliferatív és prehipertróf zónáira korlátozódik (C,D,F,H). Egyforma mértékü X-gal festődés figyelhető meg a lapocka (C), humerus $(\mathrm{C}, \mathrm{D}, \mathrm{F})$, radius $(\mathrm{D}, \mathrm{F})$, ulna $(\mathrm{D}, \mathrm{F})$, kézközépcsontok $(\mathrm{E})$ és az ujjak $(\mathrm{E})$, illetve a medencecsont $(\mathrm{K})$, femur $(\mathrm{I}, \mathrm{K})$, tibia $(\mathrm{H}, \mathrm{I}, \mathrm{L})$, fibula $(\mathrm{I}, \mathrm{L})$, lábközépcsontok $(\mathrm{G}, \mathrm{J}, \mathrm{M})$ és lábujjak (G,I,J) esetében. LacZ expresszió detektálható még az orrporcban (U) és a falcsont kezdeményében (V). Méretvonal 2 mm (B), 200 m (C-Z). További jelölések: ld. 5,7. ábrák. 


\subsection{Disztális elemek hatása heterológ promoter aktivitására}

A továbbiakban megvizsgáltuk, hogy a távoli promoter régió is képes-e egy önmagában inaktív, heterológ promoter müködését úgy irányítani, hogy a matrilin-1 génhez hasonló expressziós mintázatot kapjunk. Ehhez olyan transzgént állítottunk elő, melyben a matrilin-1 gén -2011/-946 fragmentuma a Col2al minimál promoter elé építve, azzal együtt irányítja a $L a c Z$ riporter gént (24. ábra A). A PS-PC transzgént hordozó embriók a PS-NAD1 egerekkel összehasonlítható mértékben festődtek (24. ábra B). A transzgenikus állatok hisztológiai vizsgálata arra utalt, hogy a távoli promoter régió képes az inaktív Col2al promotert aktiválni és az expressziót a fejlődő vázelemekbe irányítani. Érdekes módon az expresszió magas volt a fejlődő végtagokban és chondrocraniumban (24. ábra C-F,I,R), de alacsony a tengelyvázban, a gerincben alig detektálható (24. ábra G,H,J-O). A LacZ aktivitás szintén az oszlopos proliferatív és prehipertróf zónákra korlátozódott, tehát a zonalitás a távoli promoter elemekre is jellemző. Hasonlóan a VAM2 transzgénhez, egyéb struktúrákban is megfigyelhető volt kifejeződés, pl. az orrban (24. ábra Q,R,T,U), a metszőfog kezdeményében (24. ábra S), a gerincvelöben (24. ábra P). Viszont ellentétben a PS-NAD1 transzgénre jellemző mintázattal, itt nem figyeltük meg az arra jellemző proximo-disztális irányítottságot, sem az azonos zónában lévő sejtek különböző mértékű festődését.

Ebből arra következtetünk, hogy a matrilin-1 génre jellemző zónafüggő, porcspecifikus expresszió irányítására a távoli elemek is képesek, de a disztális struktúrákban erősebb aktivitás a rövid promoteren lévő konzervált szabályozó elemek és a távoli promoter elemek együttmüködésének eredménye. 


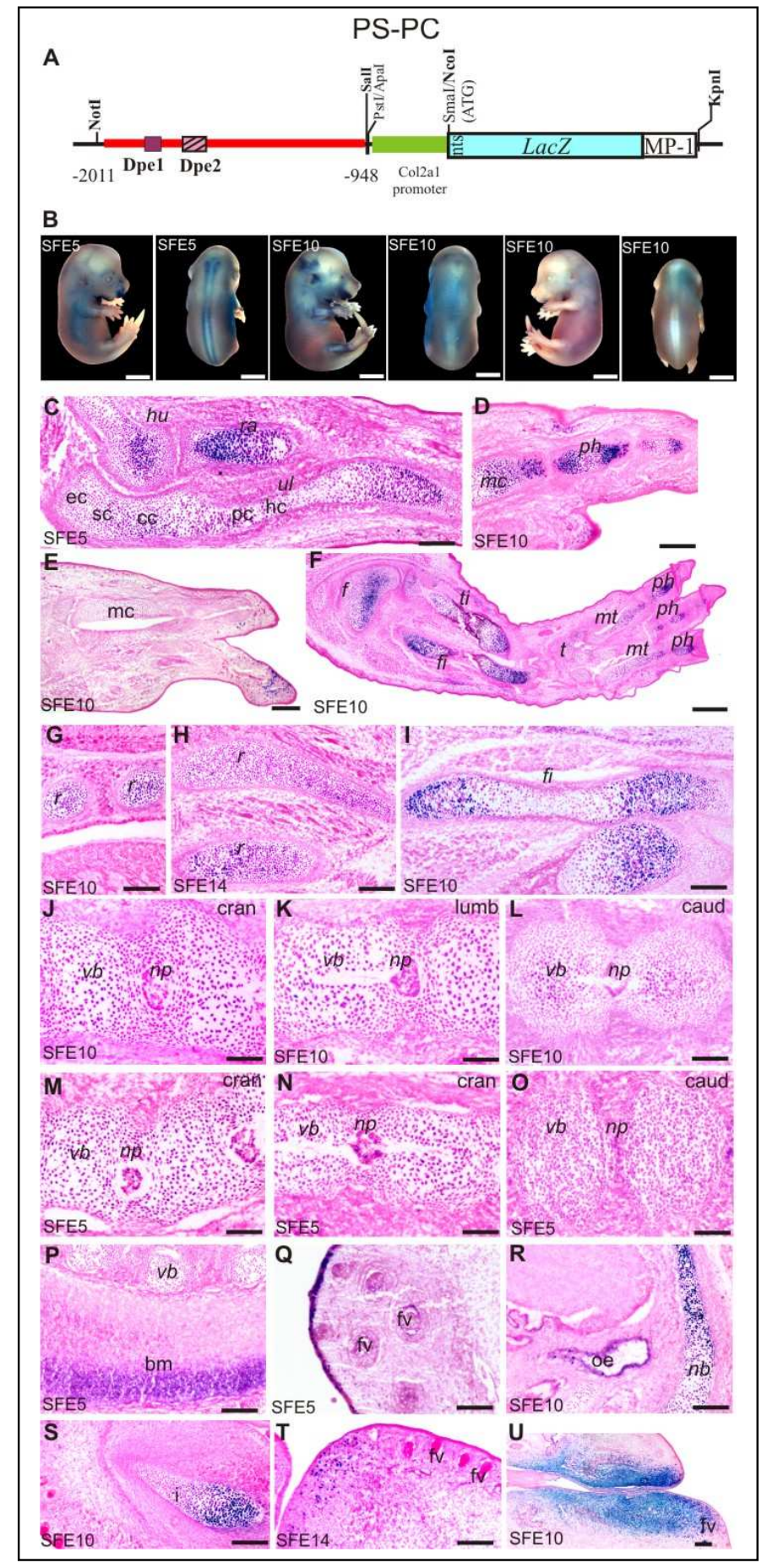

24. ábra A matrilin-1 távoli promoter régió képes az inaktív Col2a1 promotert aktiválni. A PS-PC transzgén térképe (A) és expressziós mintázata az alapító embriókban (B). A metszetek hisztológiai vizsgálatakor detektáltunk expressziót az összes fejlődő vázelemben (C-U). A LacZ kifejeződés szintje magas volt a fejlődő mellső (C-E) és hátsó végtagokban (F,I) és a chondrocraniumban (R), de alacsony a tengelyvázban $(\mathrm{G}, \mathrm{H})$, a gerincben pedig alig detektálható (J-O). A fejlődő hosszú csontok növekedési korongjaiban $L a c Z$ aktivitás az oszlopos proliferatív és prehipertróf zónákra korlátozódott (C). Megfigyelhető még transzgén kifejeződés az orrban (Q,R,T,U), a metszőfog kezdeményében (i) (S), és a gerincvelöben (bm) (P). fv, vibrissák follikulusai. Méretvonal $2 \mathrm{~mm}(\mathrm{~B}), 200 \mu \mathrm{m}$ (C-U). További jelölések: ld. 5,7. ábrák. 


\subsection{Homológ introni elemek hatása a rövid promoter aktivitására}

A matrilin-1 gén intronjában korábban azonosított 102 bp-os elem $\left(\mathrm{E}_{102}\right)$, illetve azon belül a LIE elem szabályozásban betöltött szerepét is vizsgáltuk tranziens expressziós és transzgenikus egér kísérletekben. Ezek az elemek azért keltették fel érdeklődésünket, mert korábbi kísérletekből kiderült, hogy Sox9 és Nfi kötőhelyeket tartalmaznak [108], melyek a rövid promoteren is megtalálhatók.

Megvizsgáltuk, hogy az $\mathrm{E}_{102}$ és LIE beépítése a Col2al enhancer elemek és a rövid promoter közé milyen hatást gyakorol ennek a konstrukciónak az aktivitására HDM, CEC és CEF kultúrákban tranziens expressziós kísérletben (25. ábra). A 8xE $\mathrm{Col}_{2 \mathrm{a} 1}-8 \mathrm{xLIE1-}$ FO15-Luc konstrukció viselkedése mindhárom típusú sejtkultúrában lényegében azonos volt a kiindulási, 8xE $\mathrm{Col2a1}_{1}$-FO15-Luc konstrukcióéval, vagyis ebben a környezetben a LIE elem hatása nem érvényesült. A $8 \mathrm{xE}_{\mathrm{Col} 2 \mathrm{a} 1}-8 \mathrm{xE}_{102}$-FO15-Luc konstrukció azonban HDM, CEC és CEF kultúrában is $\sim 70 \%$ relatív aktivitáscsökkenést okozott, ami szintén a transzkripciós szabályozásban betöltött negatív szerepére utal.

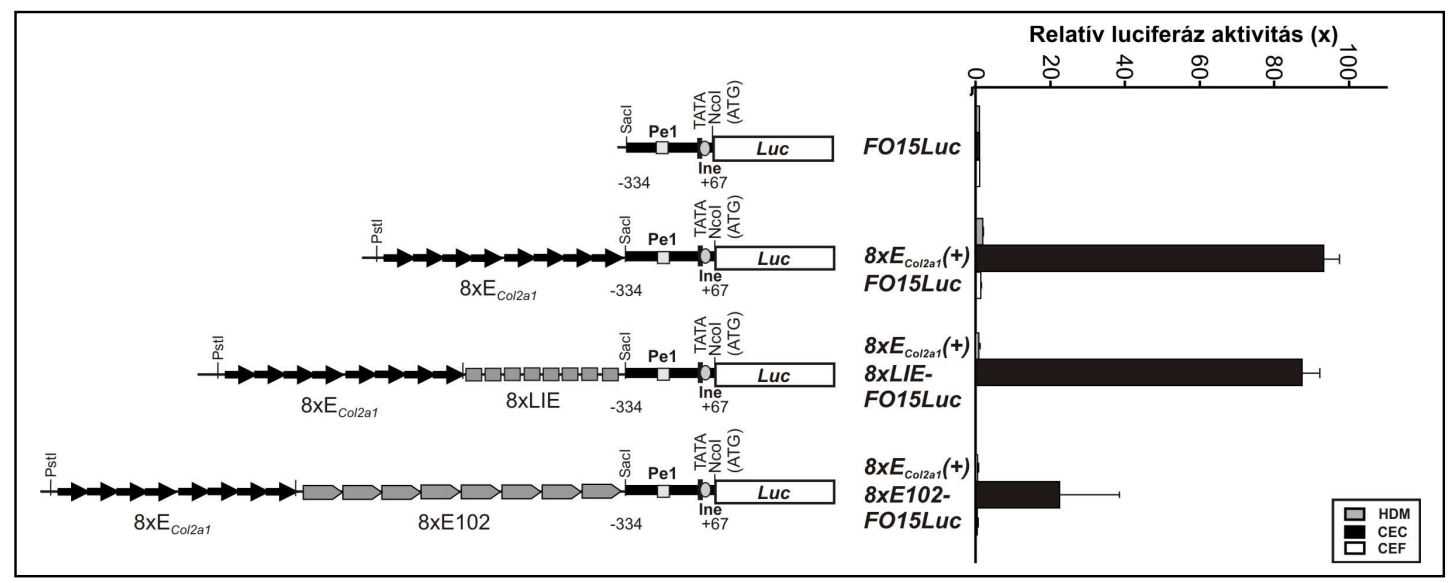

25. ábra A Col2a1 enhancer elem és a matrilin-1 introni elemek nyolc kópiájának hatása a rövid promoter aktivitására tranziens expressziós kísérletben. A diagram az egyes konstrukciók FO15-Luchoz viszonyított relatív aktivitását mutatja HDM, CEC és CEF kultúrákban.

Az Col2al enhancer elemet és az $E_{102}$, illetve a LIE elemet 8 kópiában az irodalmi adatok alapján inaktív Col2al rövid promoter által meghajtott luciferáz gén (PC-Luc) elé is beépítettük. A kontrollként használt $8 \mathrm{xE}_{\mathrm{Col} 2 \mathrm{a} 1} \mathrm{PC}$-Luc porcspecifikus aktivitása a PCLuc-hoz képest 23x-ra nőtt. A 102 bp-os elemek jelenléte mindhárom kultúrában jelentősen csökkentette a luciferáz aktivitást a $8 \mathrm{xE}_{\mathrm{Col2a1}}$-PC-Luc konstrukcióhoz képest. A LIE elemek jelenléte pedig mindhárom kultúrában 30\%-os aktivitáscsökkenéssel járt (26. 
ábra). Adataink alapján úgy tűnik, hogy a 102 bp-os elem általános transzkripciót gátló hatással bír, míg a LIE elem gátló hatása késői proliferatív porsejtekben a legkifejezettebb.

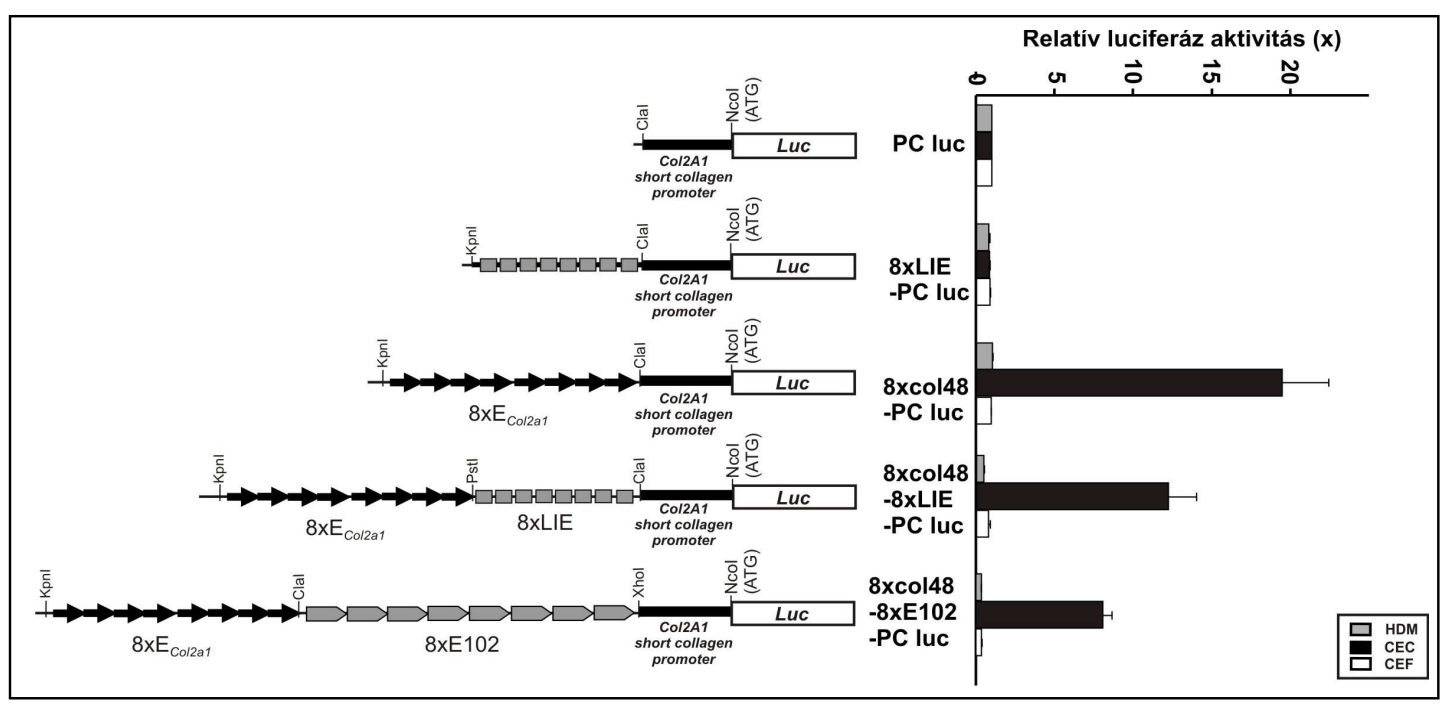

26. ábra A matrilin-1 introni elemek nyolc kópiájának hatása heterológ promoter aktivitására tranziens expressziós kísérletekben. A diagram az egyes konstrukciók PC-Luc-hoz viszonyított relatív aktivitását mutatja HDM, CEC és CEF kultúrákban.

Az $E_{102}$ elem in vivo hatásának vizsgálatához olyan konstrukciót készítettünk és állítottunk elő vele transzgenikus egereket, ami a rövid promoter előtt 4 kópiában tartalmazza ezt az elemet (27. ábra A). A 4xE $102-\mathrm{NAD} 1$ transzgenikus alapító embriók vázelemeiben nagyon alacsony szintủ expressziót figyeltünk meg, ami a NAD1 expressziós szintjét nem, vagy alig haladta meg és nem mutatott proximo-disztális irányítottságot (27. ábra B). Ezt támasztja alá, hogy a nyaki és farki gerinc régiókból származó csigolyatestek összehasonlítható mértékben festődtek (27. ábra D,E). A növekedési korongok proliferatív és prehipertróf zónáiban detektáltunk gyengén festődő sejteket, ahogy az a fejlődő hosszú csontok esetében látható (27. ábra C). 


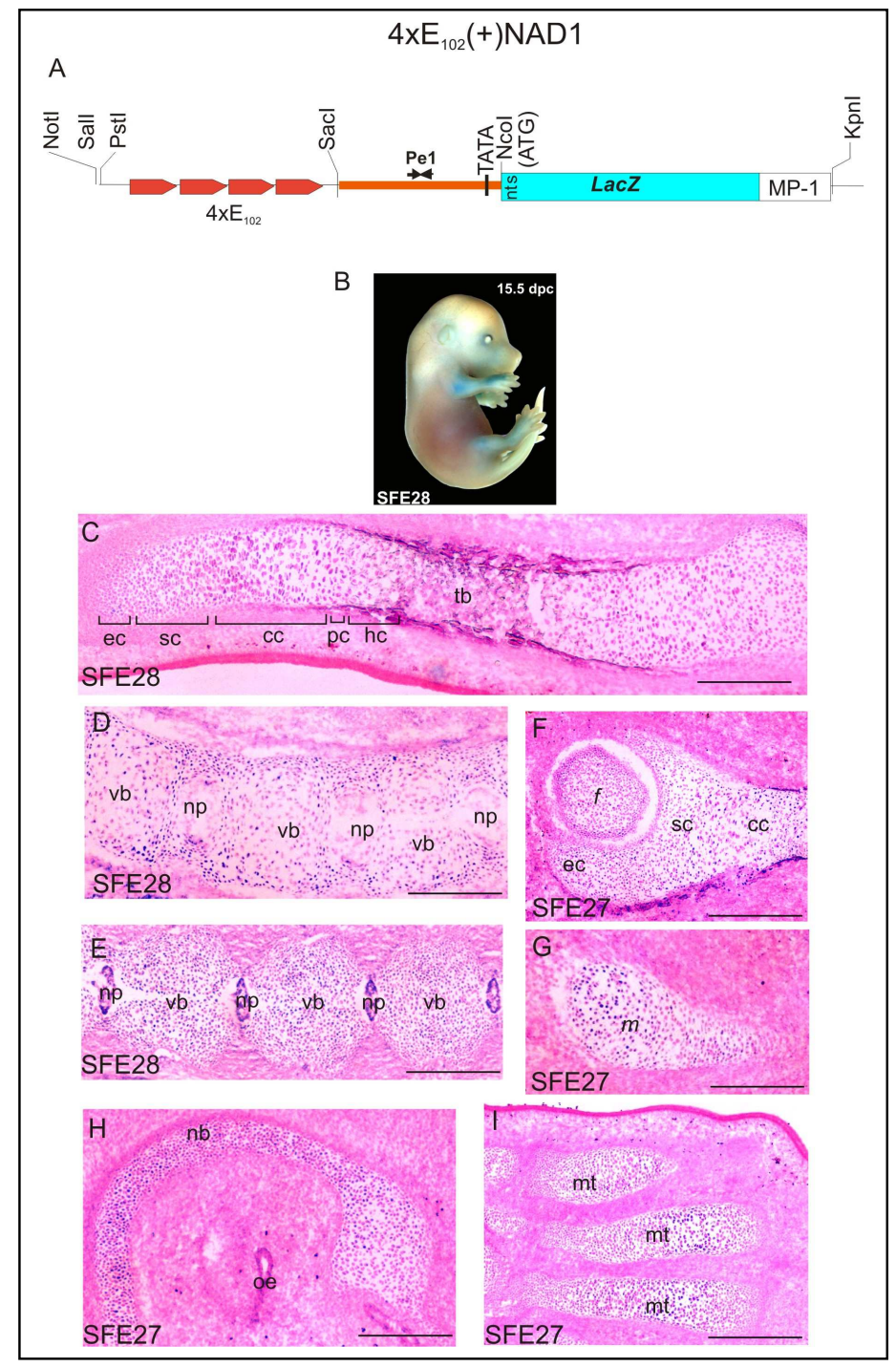

27. ábra $\mathrm{Az} \mathbf{E}_{102}$ elem négy kópiája nem növeli a rövid promoter aktivitását in vivo. A $4 \mathrm{xE}_{102}-\mathrm{NAD} 1$ transzgén térképe (A) és kifejeződési mintázata a transzgenikus alapító embrióban (B). A vázelemekben nagyon alacsony szintü expresszió figyelhető meg, ami nem mutat proximo-disztális irányítottságot, mivel a nyaki (D) és farki (E) gerinc régiók csigolyatestjei összehasonlítható mértékben festődnek. A növekedési korongok oszlopos proliferatív és prehipertróf zónáiban detektáltunk gyengén festődő sejteket (C). Szintén alacsony szintü expresszió figyelhető meg a medencecsontban (F), a Meckel-féle porcban $(\mathrm{G})$ és az orrporcban $(\mathrm{H})$. Méretvonal 2 $\mathrm{mm}$ (B), $200 \mu \mathrm{m}$ (C-I). További jelölések: 5,7. ábrák.

A 8xLIE-NAD1 transzgént (28. ábra A) hordozó állatok szintén alacsony expressziós szintet mutattak (28. ábra B), ami a NAD1 expressziós szintjét csak a fej és a bordák fejlődő porcos vázelemeiben haladta meg kissé (28. ábra B-G,J,K). Érdekes módon azonban a transzgén a fejben, az orr körüli struktúrákban nagyon magas ektopikus kifejeződést mutatott (28. ábra B-G). A proximo-disztális irányítottság itt sem érvényesült, mivel a nyaki és farki csigolyák ebben az esetben is hasonló mértékủ festődést mutattak (28. ábra H,I).

A transzgenikus egér adatok tehát összhangban vannak a tranziens expressziós és az introni elemekre vonatkozó korábbi adatokkal, melyek szerint ezek az introni elemek 
nem, vagy csak kismértékben aktiválják a rövid promotert a fejben és a tengelyvázban, és nem kifejezetten porcspecifikusak.

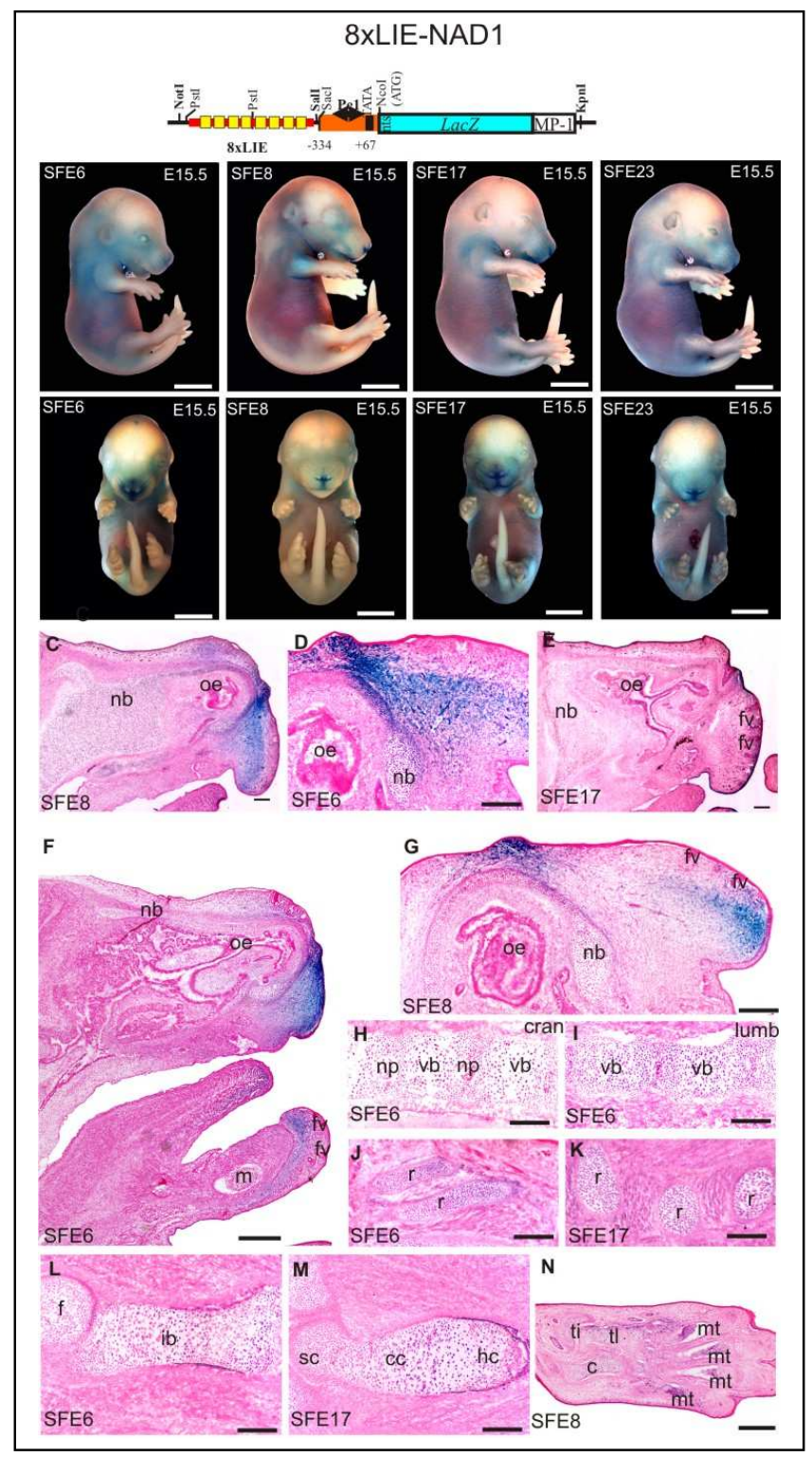

28. ábra Az introni elem nyolc kópiája nem emeli a rövid promoter aktivitását transzgenikus egerekben. A 8xLIE-NAD1 transzgén térképe (A) és expressziós mintázata az E15,5 alapító embriókban (B). A metszetek hisztológiai vizsgálata igazolta az alacsony expressziós szintet (C-N), ami csak a fej és a bordák fejlődő porcos vázelemeiben kifejezettebb kissé (C-G,J,K). A transzgén a fejben, az orr körüli struktúrákban nagyon magas ektopikus kifejeződést mutatott (C-G). A proximodisztális irányítottság nem érvényesült, mivel a nyaki $(\mathrm{H})$ és farki (I) csigolyák is hasonló mértékü festődést mutattak. Méretvonal $2 \mathrm{~mm}$ (B), $200 \mu \mathrm{m}$ (C-N). További jelölések: 5,7. ábrák. 


\section{AZ EREDMÉNYEK ÖSSZEFOGLALÁSA}

1. Transzgenikus egerekben kimutattuk, hogy a Matnl rövid promoter alacsony aktivitású a proliferatív és a prehipertróf porcsejtekben. Aktivitását távoli homológ promoter és heterológ porcspecifikus enhancer elemek nagymértékben növelik. Az önmagában alacsony aktivitása ellenére a rövid promoter domináns szerepet játszik a gén porcspecifikus, térben és időben szűkített kifejeződésének szabályozásában, sőt még erős, általános porcspecifikus enhancer aktivitását is képes térben és időben szükíteni.

2. Kimutattuk, hogy a rövid promoter müködésében kulcsszerepe van a konzervált Pe1 elem páros Sox kötőhelyének és az Ine elem Sox motívumainak.

EMSA kísérletekben igazoltuk, hogy az Ine elem két páros Sox motívuma képes tisztított Sox faktorokat kötni. Az 5' Sox kötőhely inkább Sox9-cel, míg a 3' végi Sox kötőhely inkább L-Sox5/Sox6-tal lép kölcsönhatásba.

Mutációk hatását vizsgálva a hosszú promoter aktivitására transzgenikus egerekben megállapítottuk, hogy a Pe1 elem Sox motívumait elválasztó spacer régió mutációja és az IneM2 mutáció feloldja a rövid promoter által irányított gátlást a fejlődő végtagváz proximális elemeiben, de a növekedési korongban a zonális expressziót nem változtatja meg.

3. Behatároltuk a gén távoli promoter elemeit és igazoltuk a Sox motívumokat tartalmazó Dpe1 elem fontos szerepét a rövid promoter aktiválásában.

Transzgenikus egerekben igazoltuk, hogy az elem nyolc kópiája a rövid promoter elé építve magas szintű zonális expressziót alakít ki a növekedési korongokban rendkívül erős proximo-disztális irányítottsággal a fejlődő porcos vázelemekben.

A Dpe2 elem deléciója a hosszú promoterből megszünteti a transzgén expresszió gátlását a végtagváz proximális elemeiben, de a gerinc caudális részén nem, és a zónaspecificitás is megmarad.

A Dpe1 és Dpe2 elemeket tartalmazó távoli DNS szakasz heterológ promoter elé építve is zonális kifejeződést irányít a fejlődő végtagváz elemeinek növekedési korongjaiban és a fejben. Tehát a távoli elemekre is jellemző a zónaspecificitás, de a proximo-disztális különbségek kialakításához a rövid promoter elemeire is szükség van. Más DNS elemek vesznek részt a végtagváz proximo-disztális és a gerinc cranio-caudális irányban erősödő Matnl expresszió szabályozásában. Mindettől független a zonális, azaz a fejlődési állapotspecifikus szabályozás. 
4. Vizsgáltuk a Sox és Nfi kötőhelyeket tartalmazó introni DNS elemek szerepét is a gén transzkripciós szabályozásában. Ezek a DNS elemek nem, vagy csak kis mértékben növelték a rövid promoter aktivitását például a fejben és a bordákban, és a fejben erős ektopikus kifejeződést irányítottak. A vizsgált introni elemek szerepe tehát kisebb a matrilin-1 gén szabályozásában. 


\section{DISZKUSSZIÓ}

A matrilin-1 gén egyedi tulajdonsága, hogy szemben más porcfehérjéket kódoló génekkel, melyek már a korai proliferatív porcsejtekben kifejeződnek, csak a késői proliferatív stádiumú chondrocytákban kapcsol be. In vivo a növekedési korong proliferatív és prehipertróf zónáira korlátozódik az expressziója, így e zónák markergénjének tekinthető. Mivel ezek a zónák igen fontos szerepet töltenek be a porc -és csontfejlődés során, nagy jelentősége van azon szabályozó mechanizmusok felderítésének, melyek a génexpressziót ezekbe a régiókba irányítják. A porcfehérje gének szabályozó mechanizmusaiban bekövetkező olyan hibák, amik a zonális expressziót akadályozzák, súlyos fejlődési rendellenességeket okoznak $[83,84]$. E mechanizmusok pontos felderítése hozzájárulhatna ahhoz, hogy a porcszövetet érintő betegségek és fejlődési rendellenességek korai stádiumban, még a tünetek megjelenése előtt, genetikai markerek segítségével azonosíthatóak legyenek, illetve elősegítené a megelőzés és a kezelés megfelelő stratégiáinak kidolgozását.

Munkánk során arra kerestük a választ, hogy a csirke matrilin-1 gén korábban azonosított, konzervált szabályozó elemei milyen mértékben járulnak hozzá a gén expressziójának szabályozásához, és hogy a chondrogenezist szabályozó fő transzkripciós faktorok hogyan játszanak szerepet ebben a folyamatban. Kísérleteinkkel in vivo rendszerben bizonyítottuk, hogy a matrilin-1 gén rövid promoterén lévő szabályozó elemek kulcsszerepet játszanak a génre jellemző kifejeződési mintázat kialakításában. Igazoltuk, hogy a Pe1 és Ine elemek képesek kötni a chondrogenezis fő transzkripciós faktorait, a Sox trió tagjait. További in vivo és in vitro kísérletek eredményeivel pedig alátámasztottuk, hogy a rövid promoter ezen elemei a proximális promoter szabályozó elemeivel kommunikálva müködnek.

A szabályozás egyik jellemzője, hogy a matrilin-1 szabályozó régió több, amniota fajokban különböző mértékủ homológiát mutató szekvencia elemet tartalmaz, melyeknek szerepe lehet a gén szövet -és fejlődési állapotspecifikus szabályozásában [80]. Ezek a konzervált elemek a gén rövid promoterén (-334/+67), illetve a távoli promoter régiókban helyezkednek el. Hasonló evolúciós konzerváltság figyelhető meg például a Sox2 enhancerek esetében [112], melyek a matrilin-1 szabályozó elemekhez hasonlóan elszórtan helyezkednek el hosszabb génszakaszon. A konzervált blokkok gerinces fajonként mutatnak eltéréseket, melyek a génexpresszió tér- és időbeli különbségeit tükrözik [113]. Tehát a matrilin-1 esetében is igaz lehet, hogy a szabályozó elemek 
evolúciós konzerváltsága az elemek funkcionális jelentőségét tükrözi. Ezt a következtetést eredményeink megerősítik.

A dolgozatban leírt transzgenikus egér kísérletek egyértelműen azt bizonyítják, hogy a matrilin-1 gén térben és időben szükített kifejeződésének szabályozásában kulcsszerepet tölt be a gén rövid promotere [107]. Utóbbinak az aktivitása önmagában tranziens expressziós és transzgenikus egér (NAD1) kísérletekben igen alacsony, viszont képes a rendkívül erős, általános porcspecifikus, heterológ Col2al enhancer elem [109] több kópiájának jelenléte ellenére is a matrilin-1 génre jellemzö, zonális és proximodisztális irányultságú expressziós mintázat kialakítására [114]. Ez a mechanizmus eltér a Col2a1 gén szabályozásától, mivel annak promotere önmagában inaktív, enhancerére pedig jellemző a magas szintű aktivitás minden porcsejtben, fejlődési stádiumtól függetlenül, beleértve a perichondrium, az előporc és a proliferatív zóna sejtjeit, de nem jellemző rá az a térben és időben való szűkítettség, ami a matrilin-1 gén szabályozásának sajátossága.

Szövetspecifikus szabályozó elemeket más eukarióta gének promoterében is azonosítottak, például máj- és osteoblast-specifikus gének esetében [115,116], de nem porcspecifikus génekben, melyeknek fő szabályozó elemei intronokban, vagy távoli 5' végen helyezkednek el.

Az endogén matrilin-1 génre jellemző expressziós szint kialakításában részt vesznek távoli promoter elemek is [107], hasonlóan az emlős anti-Müllerian hormon génhez, melynek TATA-boxától 100 bp távolságra azonosítottak egy konzervált DNS elemet, amit a SOX9 és partner transzkripciós faktora, az SF-1 ismer fel [117]. Ehhez hasonló mechanizmus feltételezhető a matrilin-1 gén esetében is, mivel a távoli promoter régió hosszának növelésével a porcsejtekben mért aktivitás jelentősen megnövekedett, illetve transzgenikus egerekben is a $L a c Z$ expresszió növekedését tapasztaltuk a távoli elemek jelenlétében (PB-NAD1, PS-NAD1) [114].

A matrilin-1 génre jellemző újszerü és igen hatékony, a proliferatív stádiumhoz kapcsolódó szabályozó mechanizmust más gén esetében nem írtak le. Erre a szabályozásra jellemzö, hogy a rövid promoter evolúciósan konzervált szabályozó elemei játsszák a föszerepet, melyek a porcfejlődést irányító legfontosabb transzkripciós faktorok, a Sox trió kötőhelyeit tartalmazzák [80,110].

A porcdifferenciálódást irányító fö transzkripciós faktor a Sox9, mely minden chondroprogenitor sejtben kifejeződik, hiányában a porcos elemek nem fejlődnek ki [81,82,85]. A porcszövet extracelluláris mátrixát felépítő fehérjéket kódoló gének közül a 
Col9a1, Col9a2, Coll1a2, CD-Rap és az Agc1 expresszióját is irányítja a Sox9 [91,95,97$101]$.

Eredményeink összhangban korábbi irodalmi adatokkal [80,107] és a csoportban párhuzamosan végzett EMSA, in vivo footprint és tranziens expressziós kísérletek eredményeivel együtt igazolják, hogy bár a matrilin-1 gén transzkripciós szabályozásában részt vesznek Sox faktorok, a szabályozás mégis eltér más porcfehérje génekétől.

A rövid promoteren lévő Pe1 elem Sox motívumairól in vitro EMSA és in vivo footprint kísérletekben bebizonyosodott, hogy valóban képesek a Sox trió tagjainak kötésére, melyek közül a Sox9-et preferálják, így valószínüleg a matrilin-1 gén expressziójának szabályozásában hasonló mechanizmusok is szerepet játszhatnak, mint az említett gének esetében.

A Pe1 elem esetében a Sox-kötő motívum mutációja (Pe1M1) kevesebb, mint tizedére csökkentette a hosszú promoter, és felére a Col2a1 enhancer és a rövid promoter által irányított konstrukció aktivitását tranziens expressziós kísérletekben. A két Sox motívumot elválasztó spacer régiót érintő mutáció (Pe1M4) pedig 40\%-os aktivitáscsökkenést okozott. Ez a csökkenés minden esetben csak a chondrocyta kultúrában volt megfigyelhető, míg a porcfejlődés korai stádiumát reprezentáló HDM és a matrilin-1-et nem expresszáló CEF kultúrákban nem. Tehát a Pe1 elemhez kötődő Sox faktorok döntő szerepet játszanak a gén szövetspecifikus expressziójához. Mivel a Pe1M4 mutációt hordozó transzgenikus egerek $(\Delta \mathrm{Pe} 1 \mathrm{M} 4-\mathrm{TR} 70)$ hisztokémiai analízise során azt tapasztaltuk, hogy az expresszió minden fejlődő vázelemben magas szintủ és az intakt hosszú promotert tartalmazó transzgénhez (TR70) hasonlóan zonális [107], viszont a végtagváz elemeiben elvesztette proximo-disztális irányultságát, valószínủ, hogy a Pe1 elemhez kötődő másik faktor lehet felelős a végtagváz proximális struktúráiban az expresszió gátlásáért. Ez lehet egy morfogén, vagy egy transzkripciós faktor, ami a Sox faktorokkal kölcsönhatva vesz részt a szabályozásban.

Mivel az eukarióta gének szabályozására általánosan jellemző, hogy különböző aktiváló és gátló faktorok együttműködésére van szükség a megfelelő térbeli és időbeli kifejeződéshez, a matrilin-1 gén esetében is hasonló mechanizmust feltételezünk. Valószínü, hogy a rövid promoter és a távoli promoter régiók szabályozó elemeihez kötődő Sox faktorok egymással és más fehérjékkel együttmüködve szabályozzák a gén expresszióját. Ez azért is valószínű, mert a fehérjék HMGB domént tartalmazó csoportjába tartozó Sox trió tagjai is úgy fejtik ki szabályozó szerepüket, hogy a DNS-hez kötődve meghajlítják azt, lehetőséget biztosítva ezzel partnerfaktoraiknak a kötődéshez [79]. A 
Sox9-nek számos partner faktora ismert, ilyen például az LcMaf, a PGC1 $\alpha$, illetve a Scleraxis, melyekkel együtt a Col2a1 gén szabályozásában vesz részt [118-120].

A különböző faktorok együttműködését alátámasztó másik tény, hogy a matrilin-1 rövid promoterén található SI és SII elemek funkcionális Nfi kötőhelyeket is tartalmaznak, melyek szintén tagjai a promoteren összeszerelődő PIC-nek [105,114]. A csoportban végzett újabb kísérletek ezek szerepét igazolják a Sox9 aktiváló hatásának közvetítésében.

A komplexnek része lehet még az aggrekán promoter-kötő fehérje (APBP), mely chondrocytákban in vitro kötődik a Pe1 elemhez. Hasonlóan az aggrekán promoterhez, ahol az APBP felismeröhelye több példányban, elszórtan helyezkedik el a szekvencián [121], a matrilin-1 szekvenciában is számos APBP kötőhely található a Pe1 elemen kívül is. Mivel az APBP kötődése az aggrekán promoterhez gátolja a gén transzkripcióját [121], feltételezhető, hogy a matrilin-1 szabályozásában is hasonló módon vehet részt.

Ismert az is, hogy a Col2al és Coll1a2 gének porcspecifikus enhancerében is találhatók invertált Sox motívumok, de a Pe1-hez hasonló konzervált blokk jelenléte, illetve a konszenzus Sox motívummal ilyen mértékben való megegyezés egyik génre sem jellemző $[122,123]$.

Úgy gondoljuk, hogy a Pe1 elem nem enhancerként müködve irányítja a magas szintü porcspecifikus expressziót, hiszen az intakt Pe1 elemet tartalmazó rövid promoter által irányított konstrukció meglehetősen alacsony aktivitást mutatott, illetve a Pe1 elem több példányának jelenlétében sem nőtt a minimál promoter aktivitása [80]. Sokkal inkább a távoli promoter és introni elemek hatását közvetíti azáltal, hogy velük és a hozzájuk kötődő transzkripciós faktorokkal multiprotein komplexet képez.

A rövid promoter másik, kevésbé konzervált motívuma az Ine elem. Korábbi kísérletekkel összhangban igazoltuk, hogy az Ine elem is képes Sox faktorokat kötni in vitro [111], viszont a Sox trió tagjai közül az L-Sox5 és Sox6 kötődik nagyobb affinitással. A Sox kötőhelyekben bekövetkezett mutációk ebben az esetben is jelentős mértékben csökkentették a gén aktivitását mind tranziens expressziós, mind transzgenikus egér kísérletekben. A legdrámaibb hatást az Ine elem 5' Sox kötőhelyének mutációja okozta ( $\Delta$ IneM1-TR70), mely ugyan nagymértékben lecsökkentette a transzgén aktivitását, de a zónafüggést és a proximo-disztális irányítottságot nem befolyásolta. Tehát a Pe1 elem mellett az Ine-hez kötődő Sox faktorok jelenléte is feltétele a megfelelő mértékü és mintázatú génexpressziónak. A Sox motívumok és más faktorok kötőhelyeinek a TATA-box közvetlen környezetében való csoportosulása nem jellemző más porcfehérje gének szabályozó régióira. 
A Pe1 és Ine elemek Sox motívumainak szerepére vonatkozó eredményeinket megerősítik a csoportban időközben elvégzett kotranszfekciós kísérletek. Ezek szerint a Sox9 kötődése a Pe1 elemhez kulcsfontosságú a távoli elemek aktiváló hatásának közvetítésében. A Sox9 által közvetített aktiválást szinergista és dózisfüggő módon befolyásolja az L-Sox5/Sox6, valamint Nfi faktorok is.

A proximális promoteren lévő konzervált, szövetspecifikus szabályozó elemek jelenléte egyedi tulajdonsága a matrilin-1 génnek, mivel egyéb porc mátrix fehérjéket kódoló gének (Col9a1, Col9a2, Col11a2, CD-Rap, Agc1) esetében a proximális promoter régióban nem írtak le porcspecifikus szabályozó elemeket [122-124].

Adataink alapján nyilvánvaló, hogy a Sox trió más porc mátrix génekétől (Col2al, Agcl, Crtl1) eltérő módon szabályozza a matrilin-1 gén expresszióját. Míg ezek aktiválásának elégséges feltétele a Sox9 kötődése [91,96,125], addig a matrilin-1 esetében szükség van a trió másik két tagjára is. Ahogy például a COMP promoter esetében, úgy a matrilin-1 gén aktiválásában is a Sox5 és Sox6 együttmüködik a Sox9-cel. Csoportunkban a Sox trió tagjaival végzett kotranszfekciós kísérletek is alátámasztják, hogy a porcfejlődés korai szakaszában, amikor az L-Sox5/Sox6 a Sox9-hez képest alacsonyabb moláris arányban van jelen, szabályozza a matrilin-1 promoter aktivitását azáltal, hogy elősegíti a Sox9 transzaktivációját. A chondrogenezis későbbi stádiumaiban viszont, amikor az LSox5/Sox6 nagy moláris feleslegben van a Sox9-hez képest, a transzaktiváció gátlásával csökkenti a promoter aktivitását. Hasonló együttmüködés figyelhető meg a Sox9 és a matrilin-1 promoter konzervált Nfi kötőhelyeit elfoglaló különböző Nfi izoformák között. Az Nfi fehérjék szintén mennyiségüktől függően növelik, vagy csökkentik a Sox9 transzaktivációját.

A jelen dolgozatban tárgyalt eredmények és a csoportunkban előzőleg, illetve párhuzamosan végzett in vivo és in vitro kísérletek eredményei alapján egy modellt állítottunk fel a matrilin-1 gén egyedi, szövet- és fejlődési állapotspecifikus kifejeződését szabályozó mechanizmusára (30. ábra). Hipotézisünk szerint a gén rövid és proximális promoterén modulárisan elhelyezkedő szabályozó elemek vesznek részt az expresszió irányításában. A porcfejlődés kezdeti szakaszában a Sox és Nfi fehérjéknek valószínűleg abban van szerepe, hogy a kromatin struktúra felnyitásával a TATA-box és környéke hozzáférhető legyen. Ezt támasztja alá az a megfigyelés is, hogy in vivo footprint kísérletekben a nem expresszáló CEF sejtekben a rövid promoterhez nem kötődtek fehérjék, de a porcsejtekké differenciálódó HDM kultúrában a rövid promoter fokozatosan kezdett védetté válni. Mivel az Nfi fehérjék képesek a hisztonokhoz kapcsolódni 
[126,127], valószínű, hogy a nukleoszóma struktúra fellazításával járulnak hozzá a matrilin-1 gén aktiválódásához.

A chondrogenezis korai szakaszában a Sox 9 a Pe1 elemhez kötődik. Ennek a kötődésnek a hatékonyságát az L-Sox5/Sox6 növeli, melyek ekkor a Sox9-hez képest kisebb mennyiségben vannak jelen. Valószínü, hogy a Sox faktorok kötődése a TATA-box közelében meghajlítja a DNS-t, ezáltal lehetőséget biztosít a PIC összeszerelődésére. A DNS konformációváltozása elősegítheti a Pe1 és Ine elemekhez eddig azonosítatlan faktorok (Sox partner faktorok) kötődését is. Az Ine elemen lévő Sox kötőhelyeket elfoglaló L-Sox5/Sox6 stabilizálja a Sox9-et a Pe1 elemen. Ez az elem központi szerepet játszik a PIC és az enhanceoszóma összeszerelődésében, illetve a távoli szabályozó elemek hatásának közvetítésében, de az SI-hez (és feltehetően az SII elemhez is) kötődő Nfi faktorok is jelentős mértékben hozzájárulnak e multiprotein komplexek kialakulásához. A promoter aktivitása a késői proliferatív porcsejtekben a legmagasabb, amikor a kulcsszerepeket játszó Pe1 és Ine elemeken a résztvevő Sox faktorok kötődése optimális. Ebben a stádiumban a nagy mennyiségben jelenlévő L-Sox5/Sox6 akadályozza a Sox9 transzaktivációt, feltehetően úgy, hogy a Sox faktorok a Pe1 és más elemeken lévő Sox kötőhelyekért versengenek, valamint az Ine elem Sox kötőhelyeinek teljes lefedettsége fizikailag gátolhatja a PIC müködését. A későbbi stádiumokban lecsökkent transzkripciós aktivitáshoz az is hozzájárulhat, hogy a gátló Nfi izoformák foglalják el kötőhelyeiket a szabályozó elemeken, megakadályozva ezzel a TBP TATA-boxhoz való kötődését [80,114].

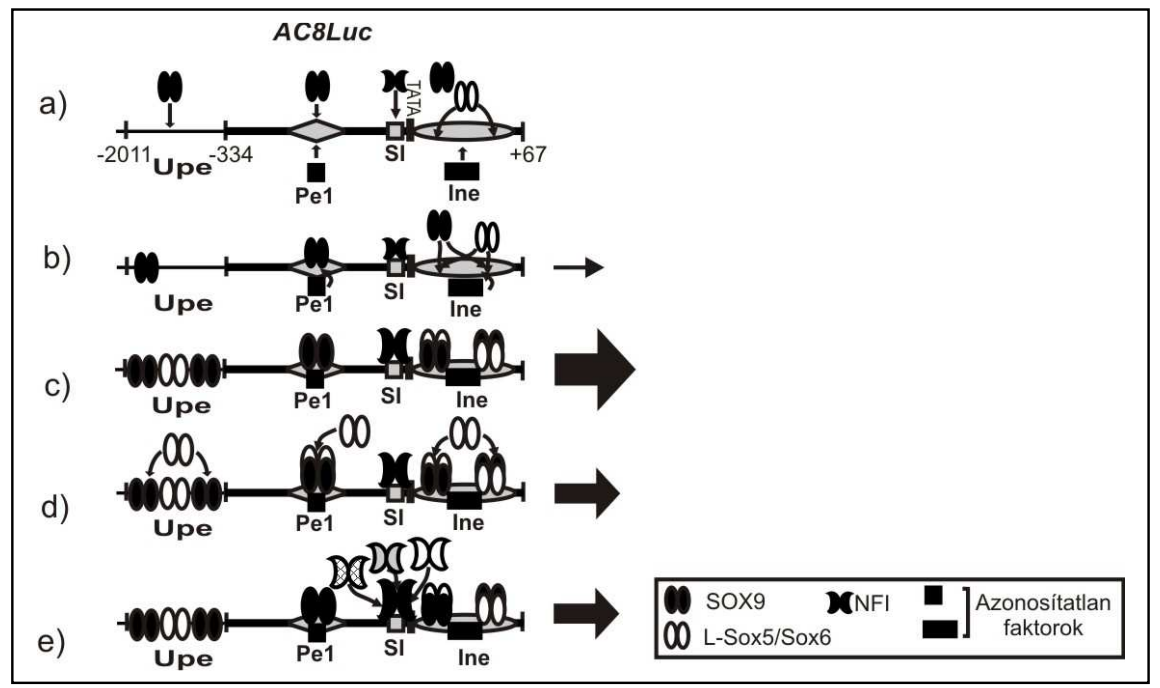

29. ábra Sox és Nfi faktorok szabályozzák a matrilin-1 promoter aktivitását. A chondrogenezis korai szakaszában (a) a Sox9 kötődik a Pe1 és Ine elemekhez. A korai (b) és késői (c) proliferatív chondroblastokban nő a kötőhelyek telítettsége. A porcfejlödés késői stádiumában az L-Sox5/Sox6 (d) és gátló Nfi izoformák (e) foglalják el a kötőhelyeket. 
A felvázolt modellt igazolják a gén távoli DNS elemeinek funkcionális vizsgálatára irányuló kísérleteink is.

Tranziens expressziós és transzgenikus egér kísérletekben behatároltuk a távoli DNS elemeket, melyeknek szerepük van a matrilin-1 gén transzkripciós szabályozásában. A távoli promoter régió még két, az emlős és csirke gének között kisebb mértékü homológiát mutató elemet tartalmaz (Dpe1 és Dpe2) [80]. A Dpe1 elemen található egy motívum, mely az L-Sox5, Sox6 transzkripciós faktorok kötőhelyével nagymértékben megegyezik [110]. A Dpe2 elem pedig a GACACAGAGAA rendkívül konzervált motívumot tartalmazza, mely egyetlen ismert transzkripciós faktor kötőhelyével sem mutat homológiát. Ezek az elemek is meghatározóak a matrilin-1 jellemző kifejeződési mintázatának kialakításában. Tranziens expressziós és transzgenikus egér kísérleteink alátámasztották, hogy a Dpe1 elem igen erős aktiváló hatású, mivel nyolc kópiája és a rövid promoter által irányított transzgén $(8 x D$ pe1-NAD1) eröteljes porcspecifikus és proximo-disztális aktivitást mutatott. Ezek az eredmények arra utalnak, hogy bár a Sox trió kötőhelyei egymástól távol helyezkednek el a matrilin-1 gén szabályozó régióban, a köztük lévő interakció feltétele a megfelelő szintủ és mintázatú génexpressziónak. Ezt támasztja alá az a megfigyelés is, hogy a Sox9 egyedül nem képes a matrilin-1 gén aktiválására, csak a Sox5 és Sox6 jelenlétében [92]. Csoportunkban párhuzamosan végzett QRT-PCR kísérletek adatai is ezt a feltevést erősítik, mivel in vitro chondrogenezis során a Sox6 mRNS szint a matrilin-1gén aktiválódásakor emelkedett meg, utalva a Sox6 szabályozásban betöltött szerepére.

A Dpe1 elemmel ellentétben a Dpe2 elem erőteljes gátló hatású, mivel tranziens expressziós kísérletekben még a több kópiában jelenlévő Dpe1 hatását is csökkenteni tudta. Érdekes módon a Dpe2 elem deléciója ( $\Delta$ Dpe2-TR70) transzgenikus egerekben megszüntette a végtagvázban a génkifejeződés proximo-disztális irányultságát, azt valószínüsítve, hogy ehhez az elemhez olyan transzkripciós faktor, vagy morfogén kötődik, mely ezekben a struktúrákban represszáló hatású.

A matrilin-1 génre egyedileg jellemző szabályozó mechanizmus felderítésével hozzájárulhatunk más porc mátrix gének szabályozásának pontosabb megértéséhez is, illetve olyan zónaspecifikus vektorok kialakításához, melyek hasznos eszközei lehetnek a vázrendszeri megbetegedések gyógyításának. Eredményeinkkel közelebb kerültünk e szabályozó mechanizmus pontos leírásához, de ez még korántsem jelenti a folyamat minden részletének ismeretét. A további vizsgálatok célja a Sox faktorokkal együttmüködő fehérjék azonosítása és kötőhelyeik meghatározása. 


\section{KÖSZÖNETNYILVÁNÍTÁS}

Munkámat az MTA Szegedi Biológiai Központ Biokémiai Intézet Kötőszövet csoportjában végeztem. Szeretném megköszönni témavezetőmnek, Dr. Kiss Ibolyának, hogy lehetőséget nyújtott a csoportjában végzett munkához, azt figyelemmel kísérte és irányította.

Köszönöm továbbá a csoport többi tagjának a munkám során nyújtott segítségüket és barátságukat.

Karcagi Ildikónak és Dr. Kénesi Erzsébetnek a módszertani tanácsokat és a „terelgetést”. Dr. Sinkó Ildikónak és Dr. Molnár Annának a mikroinjektálást és az egerek tesztelésében nyújtott segítségüket. Simonné Anikónak, Kravjár Ildikónak, Horváth Zsoltnénak és Kávai Klaudiának a nélkülözhetetlen technikai segítséget. Dr. Deák Ferencnek a hasznos tanácsokat. Dr. Korpos Évának a hisztológiai munkával kapcsolatos tanácsait. Dr. Otgonchimeg Rentsendorjnak és Szénási Tibornak az EMSA kísérletekben nyújtott segítségüket. Dr. Hunyadi-Gulyás Évának, az SZBK Proteomikai Laboratórium munkatársának a fehérjék azonosítását. Tóthné Marikának az ábrák elkészítésében nyújtott óriási segítségét.

Nem utolsó sorban a családomnak tartozom köszönettel a folyamatos és sokszor erőn felüli támogatásukért. 


\section{IRODALOMJEGYZÉK}

1. Gosline J, Lillie M, Carrington E, Guerette P, Ortlepp C, Savage K. (2002) Elastic proteins: biological roles and mechanical properties. Philos Trans R Soc Lond B Biol Sci. 28;357(1418), 121-32. Review

2. Theocharis, A. D., Skandalis, S. S., Tzanakakis, G. N. and Karamanos, N. K. (2010) Proteoglycans in health and disease: novel roles of proteoglycans in malignancy and their pharmacological targeting. FEBS J 277, 3904-3923. Minireview

3. Comper, W. D. (1996) Extracellular Matrix. Crc Press

4. Eyre, D. (2002) Collagen of articular cartilage. Arthritis Res 4, 30-35.

5. Deák, F., Wagener, R., Kiss, I. and Paulsson, M. (1999) The matrilins: a novel family of oligomeric extracellular matrix proteins. Matrix Biol. 18, 55-64.

6. Wagener, R., Ehlen, H. W. A., Ko, Y. P., Kobbe, B., Mann, H. H., Sengle, G., Paulsson, M. (2005) The matrilins- adaptor proteins in the extracellular matrix. FEBS Lett 579, 3323-3329. Minireview

7. Klatt, A. R., Becker, A. K. A., Neacsu, C. D., Paulsson, M., Wagener, R. (2011) The matrilins: Modulators of extracellular matrix assembly. Int J Biochem Cell Biol 43, 320-330.

8. Segat, D., Nitsche, P. D., Klatt, A. R., Piecha, D., Korpos, E., Deák, F., Wagener, R., Paulsson, M. and Smyth. N. (2000) Expression of matrilin-1, -2 and -3 in developing mouse limbs and heart. Matrix Biol. 19, 649-655.

9. Paulsson, M. and Heinegard, D. (1979) Matrix proteins bound to associatively prepared proteoglycans from bovine cartilage. Biochem. J. 183, 539-545.

10. Klatt, A. R., Paulsson, M., Wagener, R. (2002) Expression of matrilins during maturation of mouse skeletal tissues. Matrix Biol 21, 289-296.

11. Tsonis, P. A. and Goetinck, P. F. (1988) Expression of cartilage-matrix genes and localization of their translation products in the embryonic chick eye. Exp Eye Res. 46, 753-64.

12. Chen, Q., Johnson, D. M., Haudenschild, D. R., Tondravi, M. M., and Goetinck, P. F. (1995) Cartilage matrix protein forms a type II collagen-independent filamentous network: analysis in primary cell cultures with a retrovirus expression system. Mol. Biol. Cell 6, 1743-1753. 
13. Muratoglu, S., Bachrati, C., Malpeli, M., Szabó, P., Neri, M., Dozin, B., Deák, F., Cancedda, R. and Kiss, I. (1995) Expression of the cartilage matrix protein gene at different chondrocyte developmental stages. Eur J Cell Biol. 68, 411-8.

14. Szüts, V., Möllers, U., Bittner, K., Schürmann, G., Muratoglu, S., Deák, F., Kiss, I. and Bruckner, P. (1998) Terminal differentiation of chondrocytes is arrested at distinct stages identified by their expression repertoire of marker genes. Matrix Biol. 17, 435-448.

15. Argraves, W. S., Deak, F., Sparks, K. J., Kiss, I. and Goetinck, P. F. (1987) Structural features of cartilage matrix protein deduced from cDNA. Proc Natl Acad Sci U S A. 84, 464-468.

16. Hauser, N. and Paulsson, M. (1994) Native cartilage matrix protein (CMP): a compact trimer of subunits assembled via a coiled-coil alpha-helix. J Biol Chem. 269, 25747-53.

17. Wu, J. J. and Eyre, D. R. (1998) Matrilin-3 forms disul.de-linked 490 oligomers with matrilin-1 in bovine epiphyseal cartilage. J. Biol. Chem. 273, 17433-17438.

18. Frank, S., Schulthess, T., Landwehr, R., Lustig, A., Mini, T., Jeno, P., Engel, J. and Kammerer, RA. (2002) Characterization of the matrilin coiled-coil domains reveals seven novel isoforms. J. Biol. Chem. 277, 19071-19079.

19. Hauser, N., Paulsson, M., Heinegard, D. and Mörgelin, M. (1996) Interaction of cartilage matrix protein with aggrecan: Increased covalent cross-linking with tissue maturation. J. Biol. Chem. 271, 32247-32252.

20. Winterbottom, N., Tondravi, M. M., Harrington, T. L., Klier, F. G., Vertel, B. M., and Goetinck, P. F. (1992) Cartilage matrix protein is a component of the collagen fibril of cartilage. Dev. Dyn. 193, 266-276.

21. Makihira, S., Yan, W., Ohno, S., Kawamoto, T., Fujimoto, K., Okimura, A., Yoshida, E., Noshiro, M., Hamada, T. and Kato, Y. (1999) Enhancement of cell adhesion and spreading by a cartilage-specific noncollagenous protein, cartilage matrix protein (CMP/Matrilin-1), via integrin alpha1beta1. J Biol Chem. 274, 11417 23.

22. Huang, X., Birk, D. E. and Goetinck, P. F. (1999) Mice lacking matrilin-1 (cartilage matrix protein) have alterations in type II collagen fibrillogenesis and fibril organization. Dev. Dyn. 216, 434-441.

23. Aszódi, A., Bateman, J. F., Hirsch, E., Baranyi, M., Hunziker, E. B., Hauser, N., Bosze, Z. and Fässler, R. (1999) Normal skeletal development of mice lacking 
matrilin-1: redundant function of matrilins in cartilage. Mol. Cell. Biol. 19, 78417845.

24. Chen, Q., Zhang, Y., Johnson, D. M., Goetinck, P. F. (1999) Assembly of a novel cartilage matrix protein filamentous network: molecular basis of differential requirement of von Willebrand factor A domains. Mol Biol Cell 10, 2149-2162.

25. Aszódi, A., Hauser, N., Studer, D., Paulsson, M., Hiripi, L., and Bosze, Z. (1996) Cloning, sequencing and expression analysis of mouse cartilage matrix protein cDNA. Eur. J. Biochem. 236, 970-977.

26. Hall, B. K., Miyake, T. (1992) The membranous skeleton: the role of cell condensations in vertebrate skeletogenesis. Anat Embryol 186(2), 107-124. Review

27. Olsen, B. R., Reginato, A. M. and Wang, W. (2000) Bone development. Annu Rev Cell Dev Biol. 16, 191-220. Review

28. Goldring, M. B., Tsuchimochi, K., Ijiri, K. (2006) The control of chondrogenesis. J Cell Biochem 97, 33-44.

29. Zelzer, E., McLean, W., Ng, Y., Fukail, N., Reginatol, A. M., Lovejoy, S., D’Amore, P. A., Olsen, B. R. (2002) Skeletal defects in VEGF ${ }^{120 / 120}$ mice reveal multiple roles of VEGF in skeletogenesis. Development 129, 1893-1904.

30. Ballock, R. T., O'Keefe, R. J. (2003) The biology of the growth plate. J Bone Joint Surg Am 85, 715-726. Review

31. Farnum C. E. and Wilsman, N. J. (1998) Effects of distraction and compression on growth plate function, in Skeletal Morphogenesis and Growth. J.A. Buckwalter, et al., eds. American Academy of Orthopaedic Surgeons, Rosemont, IL. 517-532.

32. Sergerie K, Lacoursière MO, Lévesque M, Villemure I. (2009) Mechanical properties of the porcine growth plate and its three zones from unconfined compression tests. J Biomech. 11;42(4), 510-516.

33. Breur, G. J., VanEnkevort, B. A., Farnum, C. E. and Wilsman, N. J. (1991) Linear relationship between the volume of hypertrophic chondrocytes and the rate of longitudinal bone growth in growth plates. J Orthop Res. 9, 348-59.

34. Chung, U. I., Schipani, E., McMahon, A. P., Kronenberg, H. M. (2001) Indian hedgehog couples chondrogenesis to osteogenesis in endochondral bone development. J Clin Invest 107, 295-304.

35. Kronenberg, H.M. (2006) PTHrP and skeletal development. Ann. N.Y. Acad. Sci. 1068, 1-13. 
36. Lee, H., Lanske, B., Karaplis, A. C., Deeds, J. D., Kohno, H., Nissenson, R. A. et al. (1996) Parathyroid hormone-related peptide delays terminal differentiation of chondrocytes during endochondral bone development. Endocrinology 137(11), 5109-5118.

37. Kobayashi, T., Chung, U. I., Schipani, E., Starbuck, M., Karsenty, G., Katagiri, T., Goad, D. L., Lanske, B., Kronenberg, H. M. (2002) PTHrP and Indian hedgehog control differentiation of growth plate chondrocytes at multiple steps. Development (Camb) 129, 2977-2986.

38. Karaplis, A. C., He, B., Nguyen, M. T., Young, I. D., Semeraro, D., Ozawa, H. et al. (1998) Inactivating mutation in the human parathyroid hormone receptor type 1 gene in Blomstrand chondrodysplasia. Endocrinology 139(12), 5255-5258.

39. Schipani, E., Kruse, K., Juppner, H. (1995) A constitutively active mutant PTHPTHrP receptor in Jansen-type metaphyseal chondrodysplasia. Science 268(5207), 98-100.

40. Ornitz, D. M. and Marie, P. J. (2002) FGF signaling pathways in endochondral and intramembranous bone development and human genetic disease. Genes Dev. 16, 1446-1465.

41. Ornitz, D. M. (2005) FGF signaling in the developing endochondral skeleton. Cytokine Growth Factor Rev 16(2), 205-213.

42. Mackie, E. J., Ahmed, Y. A., Tatarczuch, L., Chen, K.-S., Mirams, M. (2008) Endochondral ossification: How cartilage is converted into bone in the developing skeleton. Int J Biochem Cell Biol 40, 46-62.

43. Zou H, Choe KM, Lu Y, Massagué J, Niswander L. (1997) BMP signaling and vertebrate limb development. Cold Spring Harb Symp Quant Biol. 62, 269-72. Review

44. Yoon, B. S., Lyons, K. M. (2004) Multiple functions of BMP sin chondrogenesis. J Cell Biochem 93, 93-103.

45. Minina, E., Kreschel, C., Naski, M. C., Ornitz, D. M., Vortkamp, A. (2002) Interaction of FGF, Ihh/PTH1h, and BMP signaling integrates chondrocyte proliferation and hypertrophic differentiation. Dev Cell 3, 439-449.

46. Minina, E., Wenzel, H. M., Kreschel, C., Karp, S., Gaffield, W., McMahon, A. P. et al. (2001) BMP and Ihh/PTHrP signaling interact to coordinate chondrocyte proliferation and differentiation. Development 128(22), 4523-4534. 
47. Akiyama, H., Lyons, J. P., Mori-Akiyama, Y., et al. (2004) Interactions between Sox 9 and beta-catenin control chondrocyte differentiation. Genes Dev 18, 10721087.

48. Hill, T. P., Spater, D., Taketo, M. M., Birchmeier, W., Hartmann, C. (2005) Canonical Wnt/beta-catenin signaling prevents osteoblasts from differentiating into chondrocytes. Dev Cell 8, 727-738.

49. Yang, Y., Topol, L., Lee, H., Wu, J. (2003) Wnt5a and Wnt5b exhibit distinct activities in coordinating chondrocyte proliferation and differentiation. Development 130(5), 1003-1015.

50. Mak, K. K., Chen, M. H., Day, T. F., Chuang, P. T., Yang, Y. (2006) Wnt/betacatenin signaling interacts differentially with Ihh signaling in controlling endochondral bone and synovial joint formation. Development 133(18), 3695-3707.

51. Duboc, V. and Logan, M.P.O. (2009) Building limb morphology through integration of signalling modules. Curr Op Genet Dev 19, 497-503.

52. Tabin, C.J., Wolpert, L. (2007) Rethinking the proximodistal axis of the vertebrate limbm in the molecular era. Genes Dev 21, 1433-1442.

53. Tarchini, B., Duboule, D., Kmita, M. (2006) Regulatory constraints in the evolution of the tetrapod limb anterior-posterior polarity. Nature 443, 985-988.

54. Zakany, J., Duboule, D. (2007) The role of Hox genes during vertebrate limb development. Curr Op Genet Dev 17, 359-366.

55. McGlinn, E., Tabin, C.J. (2006) Mechanistic insight into how Shh patterns the vertebrate limb. Curr Op Genet Dev 16, 426-432.

56. Mariani, F.V., Ahn, C.P., Martin, G.R. (2008) Genetic evidence that FGFs have an instructive role in limb proximal-distal patterning. Nature 453, 401-405.

57. Riddle, R.D., Ensini, M., Nelson, C., Tsuchida, T., Jessell, T.M., Tabin, C.J. (1995) Induction of the LIM homeobox gene Lmx1 by WNT7a establishes dorsoventral pattern in the vertebrate limb. Cell 83, 631-640.

58. Yang, Y., Niswander, L. (1995) Interaction between the signaling molecules WNT7a and SHH during vertebrate limb development: dorsal signals regulate anteroposterior patterning. Cell 80, 939-947.

59. Luger, K., Mader, A. W., Richmond, R. K., Sargent, D. F., Richmond, T. J. (1997) Crystal structure of the nucleosome core particle at 2,8 A resolution. Nature 389, 251-260. 
60. Happel, N. and Doenecke, D. (2009). Histone H1 and its isoforms: contribution to chromatin structure and function. Gene 431, 1-12.

61. Zhang, L., Eugeni, E.E., Parthun, M.R. \& Freitas, M.A. (2003) Identification of novel histone post-translational modifications by peptide mass fingerprinting. Chromosoma 112, 77-86.

62. Ehrenhofer-Murray, A.E. (2004) Chromatin dynamics at DNA replication, transcription and repair. Eur. J. Biochem. 271, 2335-2349.

63. Shilatifard, A., Conaway, R.C. \& Conaway, J.W. (2003) The RNApolymerase II elongation complex. Annu. Rev. Biochem. 72, 693-715.

64. Struhl, K., Kadosh, D., Keaveney, M. et al. (1998) Activation and repression mechanisms in yeast. Cold Spring Harb Symp Quant Biol 63, 413-421.

65. Riethoven, J. J. M. (2010) Regulatory regions in DNA: Promoters, enhancers, silencers, and insulators. I. Ladunga (ed), Computational Biology of Transcription Factor Binding, Methods in Molecular Biology 674, doi 10.1007/978-1-60761-8546_3 Chapter 3.

66. Sandelin, A., Carninci, P., Lenhard, B. et al. (2007) Mammalian RNA polymerase II core promoters: insights from genome-wide studies. Nature Genet 8, 424-436.

67. Carninci, P., Kasukawa, T., Katayama, S. et al. (2005) The transcriptional landscape of the mammalian genome. Science 309, 1559-1563.

68. Levine, M., and Tjian, R. (2003) Transcription regulation and animal diversity. Nature 424, 147-151.

69. Butler, J. E. F. and Kadonaga, J. T. (2001) Enhancer-promoter specificity mediated by DPE or TATA core promoter motifs. Genes Dev 15: 2515-2519.

70. Lettice, L. A., Heaney, S. J. H., Purdie, L. A., Li, L., de Beer, P., Oostra, B. A., Goode, D., Elgar, G., Hill, R. E. and de Graaff, E. (2003) A long-range Shh enhancer regulates expression in the developing limb and fin and is associated with preaxial polydactyly. Hum Mol Genet 15, 1725-35.

71. Lettice, L. A., Hill, A., E., Devenney, P. S. et al (2008) Point mutations in a distant sonic hedgehog cis-regulator generate a variable regulatory output responsible for preaxial polydactyly. Hum Mol Genet 17, 978-985.

72. Ogbourne, S. and Antalis, T. M. (1998) Transcriptional control and the role of silencers in transcriptional regulation in eukaryotes. Biochemistry 331, 1-14.

73. Gazner, M. and Felsenfeld, G. (2006) Insulators: exploiting transcriptional and epigenetic mechanisms. Nat Genet 7, 703-713. 
74. Stros, M. (2009) HMG proteins: Interactions with DNA and chromatin. Biochim Biophis Acta 1799, 101-113. Review

75. Agresti, A., Bianchi, M. E. (2003) HMG proteins and gene expression. Cur Op Gen Dev 13, 170-178.

76. Gordon, J. W., Scangos, G. A., Plotkin, D. J., Barbosa, J. A., Ruddle, F. H. (1980) Genetic transformation of mouse embryos by microinjection of purified DNA. Proc Natl Acad Sci U S A 77(12), 7380-7384.

77. Whitelaw, C. B., Archibald, A. L., Harris, S., McClenaghan, M., Simons, J. P., Clark, A. J. (1991) Targeting expression to the mammary gland: intronic sequences can enhance the efficiency of gene expression in transgenic mice. Transgenic Res 1(1), 3-13.

78. Wegner, M. (1999) From head to toes: the multiple facets of Sox proteins. Nucleic Acids Res. 27, 1409-20. Review

79. Kiefer, J. C. (2007) Back to basics: Sox genes. Dev Dyn 236, 2356-2366.

80. Rentsendorj, O., Nagy, A., Sinkó, I., Daraba, A., Barta, E., Kiss, I. (2005) Highly conserved proximal promoter element harbouring paired Sox9-binding sites contributes to the tissue- and developmental stage-specific activity of the matrilin-1 gene. Biochem J 389, 705-716.

81. Bi, W., Deng, J. M., Zhang, Z., Behringer, R. R., de Crombrugghe, B. (1999) Sox9 is required for cartilage formation. Nat Genet 22, 85-89.

82. Akiyama, H. (2008) Control of chondrogenesis by the transcription factor Sox9. Mod Rheumatol 18, 213-219. Review

83. Foster, J. W., Dominguez-Steglich, M. A., Guioli, S., et al. (1994) Campomelic dysplasia and autosomal sex reversal caused by mutations in an SRY-related gene. Nature 372, 525-530.

84. Bi, W., Huang, W., Whitworth, D. J., Deng, J. M., Zhang, Z., Behringer, R. R. and de Crombrugghe, B. (2001) Haploinsufficiency of Sox9 results in defective cartilage primordia and premature skeletal mineralization. Proc Natl Acad Sci U S A. 98, 6698-6703.

85. Akiyama, H., Chaboissier, M. C., Martin, J. F., et al. (2002) The transcription factor Sox9 has essential roles in successive steps of the chondrocyte differentiation pathway and is required for expression of Sox5 and Sox6. Genes Dev 16, 28132828. 
86. Murakami, S., Kan. M., McKeehan, W. L. and de Crombrugghe, B. (2000) Upregulation of the chondrogenic Sox9 gene by fibroblast growth factors is mediated by the mitogen-activated protein kinase pathway. Proc Natl Acad Sci USA 97, 1113 1118.

87. Huang, W., Chung, U. I., Kronenberg, H. M. and de Crombrugghe, B. (2001) The chondrogenic transcription factor Sox 9 is a target of signalling by the parathyroid hormone-related peptide in the growth plate of endochondral bones. Proc Natl Acad Sci USA 98, 160-165.

88. Murakami S, Lefebvre V, de Crombrugghe B. (2000) Potent inhibition of the master chondrogenic factor Sox 9 gene by interleukin-1 and tumor necrosis factor-alpha. J Biol Chem. 275(5), 3687-92.

89. Yu, Z., Xu, N., Wang, W., Pan, S., Li, K., Liu, J. (2009) Interleukin-1 inhibits Sox9 and collagen type II expression via nuclear factor- $\kappa \mathrm{B}$ in the cultured human intervertebral disc cells. Chinese Medical Journal 122(20), 2483-2488.

90. Tsuda, M., Takahashi, S., Takahashi, Y. and Asahara, H. (2003) Transcriptional coactivators CREB-binding protein and p300 regulate chondrocyte-specific gene expression via association with Sox9. J Biol Chem 278, 27224-29.

91. Lefebvre, V., Li, P. and de Crombrugghe, B. (1998) A new long form of Sox5 (LSox5), Sox6 and Sox 9 are coexpressed in chondrogenesis and cooperatively activate the type II collagen gene. EMBO J. 17, 5718-33.

92. Smits, P., Li, P., Mandel, J., Zhang, Z., Deng, J. M., Behringer, R. R., de Croumbrugghe, B. and Lefebvre, V. (2001) The transcription factors L-Sox5 and Sox6 are essential for cartilage formation. Dev Cell. 1, 277-290.

93. Takamatsu N, Kanda H, Tsuchiya I, Yamada S, Ito M, Kabeno S, Shiba T, Yamashita S. (1995) A gene that is related to SRY and is expressed in the testes encodes a leucine zipper-containing protein. Mol Cell Biol. 15, 3759-66.

94. Komatsu N, Hiraoka Y, Shiozawa M, Ogawa M, Aiso S. (1996) Cloning and expression of Xenopus laevis xSox12 cDNA. Biochim Biophys Acta. 1;1305, 117-9.

95. Lefebvre V, Huang W, Harley VR, Goodfellow PN, de Crombrugghe B. (1997) SOX9 is a potent activator of the chondrocyte-specific enhancer of the pro alpha1(II) collagen gene. Mol Cell Biol 17, 2336-46.

96. Lefebvre, V., Li, P. and de Crombrugghe, B. (1998) A new long form of Sox5 (LSox5), Sox6 and Sox 9 are coexpressed in chondrogenesis and cooperatively activate the type II collagen gene. EMBO J. 17, 5718-33. 
97. Genzer, M. A., Bridgewater, L. C. (2007) A Col9a1 enhancer element activated by two interdependent SOX9 dimers. Nucleic Acid Res 35, 1178-86.

98. Bridgewater, L. C., Lefebvre, V. and de Crombrugghe, B. (1998) Chondrocytespecific enhancer elements in the Col11a2 gene resemble the Col2a1 tissue-specific enhancer. J Biol Chem 273, 14998-15006.

99. Jenkins, E., Moss, J. B., Pace, J. M., Bridgewater, L. C. (2005) The new collagen gene COL27A1 contains SOX9-responsive enhancer elements. Matrix Biol 24, 177184.

100. Sekiya, I., Tsuji, K., Koopman, P., Watanabe, H., Yamada, Y., Shinomiya, K., Nifuji, A. and Noda, M. (2000) SOX9 enhances aggrecan gene promoter/enhancer activity and is up-regulated by retinoic acid in a cartilage-derived cell line, TC6. J Biol Chem 275, 10738-10744.

101. Xie, W. F., Zhang, X., Sakano, S., Lefebvre, V. and Sandell, L. J. (1999) Transactivation of the mouse cartilage-derived retinoic acid-sensitive protein gene by Sox9. J Bone Miner.Res 14, 757-763.

102. Bernard P, Tang P, Liu S, Dewing P, Harley VR, Vilain E. (2003) Dimerization of SOX9 is required for chondrogenesis, but not for sex determination. Hum Mol Genet 15, 1755-1765.

103. Kiss, I., Deák, F., Holloway, R. G., Delius, H., Mebust, K. A., Frimberger, E., Argraves, W., S., Tsonis, P. A., Winterbottom, N. and Goetnick, nP. F. (1989) Structure of the gene for cartilage matrix protein, a modular protein of the exptracellular matrix. J. Biol. Chem. 264, 8126-8134.

104. Kiss, I., Bösze, Z., Szabó, P., Rencendorj, A., Barta, E. and Deák, F. (1990) Identification of positive and negative regulatory regions controlling expression of the cartilage matrix protein gene. Mol. Cell. Biol. 10, 2432-36.

105. Szabó, P., Moitra, J., Rencendorj, A., Rákhely, G., Rauch, T. and Kiss, I. (1995) Identification of a nuclear factor-I family protein-binding site in the silencer region of the cartilage matrix protein gene. J. Biol. Chem. 270, 10212-10221.

106. Aszódi A, Módis L, Páldi A, Rencendorj A, Kiss I, Bösze Z. (1994) The zonal expression of chicken cartilage matrix protein gene in the developing skeleton of transgenic mice. Matrix Biol. 14, 181-90.

107. Karcagi, I., Rauch, T., Hiripi, L., Rentsendorj, O., Nagy, A., Bösze, Zs. and Kiss, I. (2004) Functional analysis of the regulatory regions of the matrilin-1 gene in 
transgenic mice reveals modular arrangement of tissue-specific control elements. Matrix Biol. 22, 605-618.

108. Rauch, T. (2002) Cisz reguláló elemek szerepe a matrilin-1 gén transzkripciós és poszt-transzkripciós szabályozásában. Ph.D. disszertáció, Szegedi Tudományegyetem

109. Zhou, G., V. Lefebvre, Z. Zhang, H. Eberspaecher, and B. de Crombrugghe (1998) Three high mobility group-like sequences within a 48-base pair enhancer of the Col2al gene are required for cartilage-specific expression in vivo. J. Biol. Chem. 273, 14989-14997.

110. Mertin, S., McDowall, S. G., Harley, V. R. (1999) The DNA-binding specificity of SOX9 and other SOX proteins. Nucleic Acids Res 27(5), 1359-64.

111. Rentsendorj, O. (2006) Transcriptional regulation of the matrilin-1 gene. Ph.D disszertáció, Szegedi Tudományegyetem

112. Uchikawa, M., Ishida, Y., Takemoto, T., Kamachi, Y., Kondoh, H. (2003) Functional analysis of chicken Sox2 enhancers highlights an array of diverse regulatory elements that are conserved in mammals. Dev Cell 4, 509-519.

113. Kamachi, Y., Uchikawa, M., Collignon, J., Lovell-Badge, R., Kondoh, H. (1998) Involvment of Sox1,2 and 3 in the early and subsequent molecular events of lens induction. Development 125, 2521-2532.

114. Nagy, A., Kénesi, E., Rentsendorj, O., Molnár, A., Szénási, T., Sinkó, I., Zvara, A., Thottathil Oommen, S., Barta, E., Puskás, L. G., Lefebvre, V., Kiss, I. (2011) Evolutionarily Conserved, Growth Plate Zone-Specific Regulation of the Matrilin-1 Promoter: L-Sox5/Sox6 and Nfi Factors Bound near TATA Finely Tune Activation by Sox9. Mol Cell Biol 31(4), 686-699.

115. Furlong, E. E., Rein, T., Martin, F. (1996) YY1 and NF1 both activate the human p53 promoter by alternatively binding to a composite element, and YY1 and E1A cooperate to amplify p53 promoter activity. Mol Cell Biol 16, 5933-5945.

116. Ducy, P., Karsenty, G. (1995) Two distinct osteoblast-specific cis-acting elements control expression of a mouse osteocalcin gene. Mol Cell Biol 15, 1858-1869.

117. De Santa Barbara, P., Bonneaud, N., Boizet, B., Desclozeaux, M., Moniot, B., Sudbeck, P., Scherer, G., Poulat, F., Berta, P. (1998) Direct interaction of SRYrelated protein SOX9 and steroidogenic factor 1 regulates transcription of the human anti-Mullerian hormone gene. Mol Cell Biol 11, 6653-6655. 
118. Furumatsu, T., Shukunami, C., Amemiya-Kudo, M., Shimano, H., Ozaki, T. (2010) Scleraxis and E47 cooperatively regulate the Sox9-dependent transcription. Int J Biochem Cell Biol 42, 148-56.

119. Kawakami, Y., Tsuda, M., Takahashi, S., Taniguchi, N., Esteban, C.R., Zemmyo, M., Furumatsu, T., Lotz, M., Belmonte, J.C., Asahara, H. (2005) Transcriptional coactivator PGC-1alpha regulates chondrogenesis via association with Sox9. Proc Natl Acad Sci U S A. 15, 2414-2419.

120. Huang, W., Lu, N., Eberspaecher, H. and de Crombrugghe, B. (2002) A new long form of c-Maf cooperates with Sox9 to activate the type II collagen gene. J. Biol. Chem. 277, 50668-50675.

121. Pirok, E. W., Domowicz, M. S., Henry, J., Wang, Y., Santore, M., Mueller, M. M., Schwartz, N.B. (2005) APBP-1, a DNA/RNA-binding protein, interacts with the chick aggrecan regulatory region. J Biol Chem 280(42), 35606-16.

122. Zhou, G., Garofalo, S., Mukhopadhyay, K., Lefebvre, V., Smith, C. N., Eberspaecher, H., de Crombrugghe, B. (1995) A 182 bp fragment of the mouse proa1(II) collagen gene is sufficient to direct chondrocyte expression in transgenic mice. J Cell Sci 108, 3677-3684.

123. Tsumaki, N., Kimura, T., Matsui, Y., Nakata, K. and Ochi, T. (1996) Separable cis-regulatory elements that contribute to tissue- and site-specific $\alpha 2(\mathrm{XI})$ collagen gene expression in the embryonic mouse cartilage. J. Cell Biol. 134, 1573-1582.

124. Xie, W. F., Zhang, X. and Sandell, L. J. (2000) The 2.2-kb promoter of cartilagederived retinoic acid-sensitive protein controls gene expression in cartilage and embryonic mammary buds of transgenic mice. Matrix Biol. 19, 501-509.

125. Han, Y., Lefebvre, V. (2008) L-Sox 5 and Sox6 drive expression of the aggrecan gene in cartilage by securing binding of Sox9 to a far-upstream enhancer. Mol Cell Biol 28, 4999-5013.

126. Alevizopoulos, A. et al. (1995) A proline-rich TGF- $\beta$-responsive transcriptional activator interacts with histone H3. Genes Dev 9, 3051-3066.

127. Gronostajski, R. M. (2000) Roles of the NFI/CTF gene family in transcription and development. Gene 249, 31-45.

128. Oommen, S. T. (2006) Contribution of control elements to the cartilage-specific activity of the matrilin-1 promoter. Proceedings of the ITC closing seminar, MTA Szegedi Biológiai Központ 
129. De Crombrugghe, B., Lefebvre, V., Nakashima, K. (2001) Regulatory mechanisms in the pathways of cartilage and bone formation. Curr Op Cell Biol 13, 721-727.

130. Gamma Sosa, M. A., De Gasperi, R., Elder, G. A. (2010) Animal transgenesis: an overview. Brain Struct Funct 214, 91-109. 


\section{A TÉZISEK ÖSSZEFOGLALÁSA}

\section{Bevezetés}

A porcszövet a gerinces vázrendszer kialakulásában és müködésében fontos szerepet betöltő szövettípus. Sejtes komponensei a chondrocyták, melyek a porcszövetre jellemző makromolekulákat termelik. Ezek a sejten kívüli térben egy jól szervezett, kiterjedt extracelluláris mátrixot (ECM) hoznak létre, amely meghatározza a szövet fizikai és kémiai tulajdonságait.

A gerincesek vázrendszerének nagy része endochondrális csontosodás útján alakul ki. Ebben a folyamatban a porcszövet egy átmeneti struktúra, amely végül teljes mértékben átalakul. Az endochondrális csontosodást szabályozó legfontosabb transzkripciós faktor a Sox9, amely már a mesenchyma sejtek kondenzációjához is nélkülözhetetlen. A Sox9 az L-Sox5/Sox6-tal és más partner faktoraival együtt irányítja a folyamatot.

A porcdifferenciálódás első lépése a mesenchyma sejtek kondenzációja. A kondenzáció központjában levő sejtek előbb prechondrocytákká, majd chondroblastokká fejlődnek, amik intenzíven osztódnak és elkezdik termelni a porcszövetre jellemző mátrix fehérjéket (II., IX., XI. típusú kollagén, aggrekán). A periférián levő néhány sejtréteg fibroblaszt-szerü perichondriális sejtté alakul. A chondroblastok gyorsan osztódnak, korai és késői proliferatív stádiumokon keresztülhaladva hipertróf porcsejtekké differenciálódnak. Később kapillárisok lépnek a fejlődő csontba, amik az apoptózissal elhalt hipertróf sejteket eltávolító chondroclastokat és újabb differenciálatlan mesenchyma sejteket hoznak. A következő lépésben a mátrix mineralizálódik. Az epifízeális porcok felszíni rétege nem fejlődik csonttá, hanem ízületi porcként funkcionál életünk végéig.

Az epifízeális porc és a csontok hosszanti növekedése a felnőtt kor eléréséig a növekedési koronghoz köthető. Az itt lévő chondrocyták morfológiailag és génexpresszió alapján is elkülöníthető zónákba rendeződnek, melyek megfelelnek az embrionális porcfejlődési stádiumoknak. A diafízistől legtávolabb található a forrás chondrocyták zónája. Ezek a sejtek kicsik, azonos alakúak és gyorsan osztódnak. A következő zónát az oszlopos proliferatív porcsejtek alkotják, ezek lassabban osztódnak, oszlopokba rendeződnek, melyeken lefelé haladva az osztódás intenzitása csökken. A proliferációt követően a sejtek egy átmeneti prehipertróf zónába rendeződnek. Az epifízis-diafízis határhoz legközelebb eső, nagyobb méretü, szabálytalan alakú chondrocyták alkotják a 
hipertróf zónát, melynek sejtjei X. típusú kollagén mátrixot termelve előmintázatot szolgáltatnak a belépő osteoblasztoknak a csontos mátrix kialakításához. Az endochondrális csontosodás minden lépésében az adott stádiumra jellemző markergének kifejeződése figyelhető meg.

A matrilin család tagjai olyan nem-kollagénszerü fehérjék, melyek a porcszövet sejtközötti állományának felépítésében úgy vesznek részt, hogy kollagéntől függő és attól független finom hálózatokat alkotnak. Az ECM szervezödésében betöltött fontos szerepükre utal, hogy minden szövettípus sejtközötti állományában elöfordul a család egy, vagy több tagja.

A család közül elsőként azonosított tagja a matrilin-1. Más porcfehérjéktől eltérően, melyek már a korai proliferatív porcsejtekben termelődnek, a matrilin-1 csak a késői proliferatív stádiumú chondrocytákban termelődik. A gén expressziója in vivo a növekedési korong proliferatív és prehipertróf zónáira korlátozódik, így e zónák markergénjének tekinthető. A csirke matrilin-1 gén hosszú promotere transzgenikus egerekben a fejlödő hosszú csontok növekedési korongjának proliferatív és prehipertróf zónáiba irányítja az expressziót. A kifejeződési mintázatra jellemző még a proximodisztális irányítottság.

\section{Célkitűzések}

Munkánk során arra kerestük a választ, hogy a gén korábban már azonosított szabályozó elemei közül melyik és milyen mértékben járul hozzá a szövet- és fejlődési állapotspecifikus kifejeződéshez, valamint hogy azonos, vagy különböző DNS szakaszok felelősek-e ezért a szabályozásért. A DNS elemek behatárolása mellett arra is kíváncsiak voltunk, hogy a matrilin-1 transzkripciós szabályozása mennyiben azonos, illetve tér el más porc mátrix fehérjéket kódoló génekétől (pl. Col2al).

\section{Kísérleti stratégia}

Kérdéseink megválaszolása érdekében a következő kísérleti stratégiát követtük. A már korábban leírt reguláló elemek különböző kombinációival riporter konstrukciókat hoztunk létre, melyek aktivitását tranziens expressziós kísérletekben különbözö sejtkultúrákban vizsgáltuk. A riporter konstrukciók közül azokat választottuk ki, melyek hatással voltak a matrilin-1 gén szövet -és fejlődési állapotspecifikus expressziójára. Ezekkel a DNS elem kombinációkkal LacZ riporter konstrukciókat készítettünk, melyekkel transzgenikus egereket hoztunk létre, hogy hatásukat in vivo vizsgálhassuk. Az 
injektálásból származó alapító, illetve a transzgenikus vonalakból származó embriókban hisztológiai módszerekkel vizsgáltuk a génkifejeződés tér -és időbeli tulajdonságait. E kísérletek alapján behatároltuk a mintázatért felelős DNS elemeket. Ezt követően a vizsgált szabályozó elemekben pontmutációkat hoztunk létre, melyek in vivo hatását szintén megviszgáltuk transzgenikus egerekben. A szabályozásban résztvevő Sox faktorok kötődését in vitro EMSA kísérletekben vizsgáltuk.

\section{Eredmények}

Kimutattuk, hogy a matrilin-1 rövid promoter önmagában alacsony aktivitású proliferatív és prehipertróf porcsejtekben. Aktivitását távoli homológ és heterológ porcspecifikus enhancer elemek nagymértékben növelik. Alacsony aktivitása ellenére a rövid promoter kulcsfontosságú a gén szűkített tér -és időbeli kifejeződésének szabályozásában, sőt még erős, általános porcspecifikus enhancer elem aktivitását is képes szükíteni.

EMSA kísérletekben igazoltuk, hogy az Ine elem páros Sox motívumai tisztított, GST-fúziós Sox fehérjékkel képesek nukleoprotein komplexet létrehozni. Az 5' végi Sox kötőhely inkább Sox9-cel, míg a 3' végi motívum inkább L-Sox5/Sox6-tal alkot komplexet.

A konzervált elemek pontmutációinak hatását a hosszú promoter aktivitására tranziens expressziós kísérletekben vizsgálva igazoltuk, hogy a Pe1 elem páros Sox motívumainak mutációja drámai módon csökkenti a génexpressziót. Transzgenikus egér kísérletek során pedig megállapítottuk, hogy a Pe1 elem spacer régiójának és az Ine elem egy Sox kötőhelyének mutációja feloldja a rövid promoter által irányított gátlást a végtagváz proximális elemeiben, de a fejlődési állapotspecifikus expressziót nem változtatja meg.

Eredményeink bizonyítják, hogy a rövid promoter müködésében rendkívül fontos szerepet játszanak annak evolúciósan konzervált DNS elemei. A Pe1 elem páros Sox9 kötőhelyei és az Ine elem Sox motívumai esszenciálisak a megfelelő kifejeződés irányításában.

A Dpe1 és Dpe2 elemeket tartalmazó távoli DNS régió nagymértékben növeli a rövid promoter aktivitását, illetve heterológ promoter aktivitását is a növekedési korong meghatározott zónáiba irányítja. Igazoltuk az ebben a régióban elhelyezkedő Dpe1 elem fontos szerepét a rövid promoter aktiválásában, illetve transzgenikus egér adatokkal is 
alátámasztottuk, hogy az elem nyolc kópiája a rövid promoter elé építve zonális kifejeződést irányít nagyon erős proximo-disztális irányítottsággal.

A Dpe2 elem deléciója a hosszú promoterből megszünteti a gátló hatást a proximális vázelemekben, de a zónaspecificitás megmarad.

Ezek alapján elmondható, hogy a távoli elemek is zónaspecifikus aktivitással bírnak, de a proximo-disztális különbségek kialakításához a rövid promoter elemeire is szükség van.

Vizsgáltuk továbbá Sox és Nfi kötőhelyeket tartalmazó introni elemek szerepét is a gén transzkripciós szabályozásában. Ezek nem, vagy csak kismértékben növelték a rövid promoter aktivitását elsősorban a fejben, ahol mindez erős ektopikus kifejeződéssel társult. Ezen elemek szerepe tehát kisebb a matrilin-1 gén transzkripciós szabályozásában.

A proximális promoteren lévő konzervált, szövetspecifikus szabályozó elemek jelenléte egyedi tulajdonsága a matrilin-1 génnek, mivel egyéb porcmátrix fehérjéket kódoló gének (Col9a1, Col9a2, Col11a2, Agc1, CD-Rap) esetében a proximális promoter régióban nem írtak le porcspecifikus szabályozó elemeket.

\section{Az eredmények megvitatása}

Eredményeink, összhangban a csoportban párhuzamosan végzett kísérletek eredményeivel igazolják, hogy a matrilin-1 gén transzkripciós szabályozása eltér más porcspecifikus génekétől (pl. Col2al, $A g c$ ). A szabályozásban a rövid promoter kulcsfontosságú. Ezt bizonyítja, hogy önmagában képes az erős, általános porcspecifikus Col2a1 enhancer aktivitását is leszükíteni. A rövid promoteren lévő, evolúciósan konzervált szabályozó elemek (Pe1,Ine), melyek képesek a chondrogenezis fő regulátorait (Sox9, L-Sox5/Sox6) in vitro kötni, játsszák a föszerepet a gén szükített, szövet -és fejlődési állapotspecifikus szabályozásában. A reguláló elemek ehhez hasonló, a TATAbox körüli csoportosulását eddig más porcfehérje gén esetében nem írták le.

A Pe1 és az Ine elemek Sox motívumaihoz a Sox9 kötődése szükséges, de nem elégséges feltétele a megfelelő szintű génexpressziónak, eltérően például a Col2al, Agc, Crtl1 génektől. A Sox9 hatását az L-Sox5/Sox6 szinergista és dózisfüggő módon növeli.

A Pe1 elem páros Sox motívumai rendkívül nagy homológiát mutatnak a konszenzus Sox motívummal, ami szintén a matrilin-1 gén egyedi tulajdonsága.

Sox és Nfi transzkripciós faktorok és valószínüleg más faktorok kötőhelyei találhatók még a távoli promoter régióban, melyek hatását a rövid promoter elemei közvetítik. 
A dolgozatban tárgyalt eredmények, illetve a csoportban előzőleg és párhuzamosan végzett kísérletek alapján felállítottunk egy modellt a matrilin-1 gén szövet -és fejlődési állapotspecifikus szabályozására vonatkozóan. Eszerint a porcfejlődés kezdeti szakaszában a Sox9 a Pe1 elemhez kötődik. A kötődés hatékonyságát az L-Sox5/Sox6 növeli, melyek ekkor még a Sox9-hez képest kisebb mennyiségben vannak jelen. A Sox faktorok valószínűleg a DNS konformációváltozását idézik elő, ami lehetőséget biztosít partner faktoraiknak a kötődésre. A promoter aktivitása a késői proliferatív porcsejtekben a legmagasabb, amikor a Pe1 és Ine elemeken a Sox faktorok kötődése optimális. Ekkor a nagy mennyiségben jelenlévő L-Sox5/Sox6 akadályozza a Sox9 transzaktivációt, feltehetően a kötőhelyekért való versengés által. A későbbi stádiumokban lecsökkent transzkripciós aktivitáshoz az is hozzájárulhat, hogy a gátló Nfi izoformák foglalják el kötőhelyeiket a szabályozó elemeken.

A matrilin-1 gén egyedi szabályozó mechanizmusának felderítésével hozzájárulhatunk olyan zónaspecifikus vektorok kialakításához, melyek hasznos eszközei lehetnek a vázrendszeri betegségek gyógyításának. 


\section{SUMMARY OF THE THESIS}

\section{Introduction}

Most of the vertebrate skeleton forms through endochondral ossification. This process requires a cartilaginous template of the future bones. The first step of endochondral bone formation is the condensation of mesenchymal cells. In the center of the condensations cells differentiate into prechondrocytes and later chondroblasts which start to deposit an extracellular matrix characteristic of cartilaginous tissues, comprising mainly of type II, IX., XI. collagen, aggrecan, chondromodulin-1. A few cell layers at the periphery develop into fibroblast-like perichondrial cells. Chondroblasts sequentially differentiate into proliferating, prehypertrophic and hypertrophic chondrocytes. Later capillaries invade carrying osteoclasts which degrade the hypertrophic cartilage matrix. Osteoblasts then produce bone-specific matrix. The layer of epiphyseal chondroblasts does not develop into bone but functions as articular cartilage.

Developing chondrocytes establish growth plates in which the cells are arranged in layers according to their developmental stages. The zone further from the bone diaphysis is the source zone. These cells are small, dividing rapidly. In the columnar proliferating zone cells dividing slower, arrange into columns. Bone growth is determined by the number of cells proliferating in the columnar zone and progress through hypertrophy. After the prehypertrophic stage cells form the hypertrophic zone. These are larger and irregularly shaped cells. Each step of endochondral bone formation has its characteristic set of marker genes expressed.

The master transcription factor governing chondrocyte differentiation is Sox9. Together with L-Sox5 and Sox6 they form the Sox trio. Both of them are required and sufficient to induce chondrogenesis.

Members of the matrilin protein family are non-collagenous, oligomeric extracellular adaptor proteins. They form both collagen-dependent and -independent networks in the cartilage extracellular matrix. They are present in several other tissue types highlighting their importance in matrix assembly.

The first identified member of the matrilin family is matrilin-1. Its coding gene (Matnl) has the unique feature among other cartilage matrix genes that it is expressed in later stages of chondrogenesis. In vivo its expression is restricted to early proliferative and prehypertrophic chondrocytes of the growth plate, therefore it can be considered as a marker gene of this stage. The long promoter of the chicken matrilin-1 gene directs the 
expression to the columnar proliferative and prehypertrophic zones of the growth plate in transgenic mice.

\section{Aims of the study}

In our studies we wanted to identify the contribution of previously characterized regulatory elements to the tissue -and developmental stage-specific regulation of the gene. We also wanted to investigate the similarities and differences between the regulatory mechanism of Matn1 and other cartilage protein genes.

\section{Experimental strategy}

To gain insight into the transcriptional regulation of the gene, we used the following experimental strategy. We generated reporter constructs with different combinations of the regulatory elements and studied their activity in transient expression assays in different cell cultures. Among the reporter constructs we picked those which affected the tissue -and developmental stage-specific expression of the gene. With these combinations of DNA elements we generated transgenic mice to study their in vivo effect. Histological methods were used to study the spatial and temporal expression pattern of the gene in founder embryos and embryos from transgenic lines. Based on these experiments we defined the regulatory regions responsible for this unique expression pattern.

Within the examined regulatory elements point mutations were generated and their effects were also tested in transgenic mice.

With in vitro EMSA experiments we studied the binding characteristics of purified Sox factors to the regulatory elements.

\section{Results}

We showed that the matrilin-1 short promoter alone exhibits low activity in the proliferative and prehypertrophic zones of the growth plate. Its activity was significantly increased by homologous and heterologous cartilage-specific enhancer elements. Despite of its low activity the short promoter plays pivotal role in the restricted tissue -and developmental stage-specific regulation of the gene. Moreover it can even inhibit the Col2a1 general cartilage-specific enhancer in proximal structures and at early differentiation stages. 
In EMSA experiments we showed that the paired Sox motifs of the Ine element are capable of binding purified, GST-fused Sox proteins. The 5' motif prefers to form nucleoprotein complex with Sox9, while the 3' motif rather binds L-Sox5/Sox6.

In transient expression assays we showed that mutations in the paired Sox motifs of the Pe1 element dramatically decrease the activation of the long promoter.

Based on the effect of point mutations of the conserved elements in transgenic mice, we concluded that mutation in the spacer region of the Pe1 element and one of the Ine Sox motifs eliminates the inhibitory effect of the short promoter in the proximal skeletal structures, but does not alter the developmental stage-specific expression.

The evolutionarily conserved DNA elements of the short promoter have crucial role in its activity. The paired Sox9 binding sites of the Pe1 element and the Sox motifs of the Ine element are essential for driving proper expression pattern.

The proximal promoter region which contains the conserved Dpe1 and Dpe2 elements largly increased the activity of the short promoter. It also directed the activity of a heterologous promoter to certain zones of the growth plate.

We proved the important role of Dpe1 element in the activation of the short promoter in transient expression experiments. Eight copies of this element together with the short promoter direct zonal expression with extremely high level in distal structures in transgenic mice.

Deletion of the Dpe2 element from the long promoter erased the inhibitory effect in proximal structures, but did not affect the zonal expression pattern.

From these results we concluded that the proximal elements also have zonespecific activity, but short promoter elements are also needed for generating proximodistal differences.

We also studied the role of intronic elements containing Sox and Nfi binding sites. These regions had no or mild effect on the activity of the short promoter, driving strong expression mainly in the head accompanied by high level ectopic expression. Thus these elements play minor role in the transcriptional regulation of the matrilin-1 gene.

\section{Discussion}

Our results, in concordance with parallel findings in our group, confirm that the transcriptional regulatory mechanisms of the matrilin-1 gene differs from other cartilagespecific genes (Col2al, $A g c)$. The evolutionarily conserved regulatory elements of the short promoter (Pe1, Ine), which can bind the master transcription factors of 
chondrogenesis (Sox9, L-Sox5/Sox6) in vitro, play the key role in the restricted expression pattern of the gene. The modular arrangement of regulatory elements around TATA is a unique feature of the matrilin-1 gene.

Binding of Sox 9 to the Sox motifs of Pe1 and Ine is required but not sufficient for the proper expression level, differing from the Col2al, Agc and Crtl genes. L-Sox5 and Sox6 modulates the effect of Sox9 in a dose-dependent and sinergistic manner.

The distal promoter region harbours binding sites for Sox, Nfi and other yet unidentified factors. Their effect is likely mediated by the short promoter elements. Presence of tissue-specific regulatory elements in the proximal promoter region is also a characteristic of the matrilin-1 gene.

Based on the results discussed in this thesis together with pervious and parallel works in our group we proposed a model for the unique regulatory mechanism of the matrilin-1 gene. According to this, at the early stage of chondrogenesis Sox9 binds to the Pe1 element. L-Sox5/Sox6, which is expressed at lower molar excess relative to Sox9, secures this binding.

Binding of Sox factors near TATA may bend the DNA and facilitate the binding of components of the PIC (preinitiation complex). The promoter activity is highest in late proliferative chondroblasts when the occupancy of Sox motifs on Pe1 and Ine are optimal. At this time the large molar excess of L-Sox5/Sox6 to Sox 9 decresae its transactivation, possibly by competing for binding Pe1 and other elements. The decreased transcriptional activity may possibly due to repressor Nfi isoforms binding to the regulatory elements.

Describing of the unique regulatory mechanism of the matrilin-1 gene can facilitate the construction of growth plate zone-specific vectors and the development of biotechnological therapies for skeletal diseases. 


\section{A DOLGOZAT ALAPJÁUL SZOLGÁLÓ KÖZLEMÉNYEK}

1. Rentsendorj, O., Nagy, A., Sinkó, I., Daraba, A., Barta, E., Kiss, I. (2005) Highly conserved proximal promoter element harbouring paired Sox9-binding sites contributes to the tissue- and developmental stage-specific activity of the matrilin1 gene. Biochem J 389, 705-716.

2. Nagy, A., Kénesi, E., Rentsendorj, O., Molnár, A., Szénási, T., Sinkó, I., Zvara, A., Thottathil Oommen, S., Barta, E., Puskás, L. G., Lefebvre, V., Kiss, I. (2011) Evolutionarily Conserved, Growth Plate Zone-Specific Regulation of the Matrilin1 Promoter: L-Sox5/Sox6 and Nfi Factors Bound near TATA Finely Tune Activation by Sox9. Mol Cell Biol 31(4), 686-699.

3. Magyar és nemzetközi szabadalmi bejelentés

Címe: „Porcspecifikus vektorok és porcspecifikus génmüködés követésére alkalmas transzgenikus állatmodellek kidolgozása”

Bejelentés alapszáma: P0700457

Bejelentés időpontja: 2007. július 3.

Dr. Kiss Ibolya, Dr. Molnár Annamária, Nagy Andrea, Dr. Kénesi Erzsébet

\section{A DOLGOZAT TÉMÁJÁHOZ KAPCSOLÓDÓ EGYÉB KÖZLEMÉNY}

1. Karcagi, I., Rauch, T., Hiripi, L., Rentsendorj, O., Nagy, A., Bősze, Zs. and Kiss, I. (2004) Functional analysis of the regulatory regions of the matrilin-1 gene in transgenic mice reveals modular arrangement of tissue-specific control elements. Matrix Biol. 22, 605-618. 
